Review

\title{
Metal assisted peptide bond hydrolysis: Chemistry, biotechnology and toxicological implications
}

\author{
Nina E. Wezynfeld, Tomasz Frączyk, Wojciech Bal* \\ Institute of Biochemistry and Biophysics, Polish Academy of Sciences, Pawińskiego 5a, 02-106 Warsaw, Poland
}

\section{Contents}

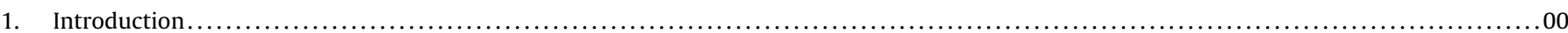

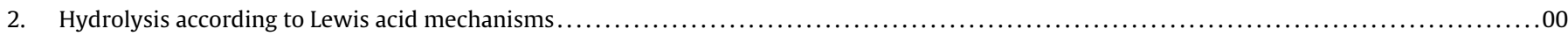

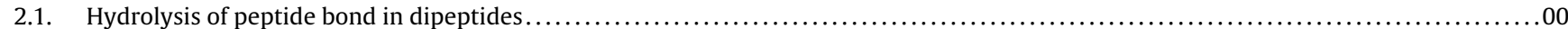

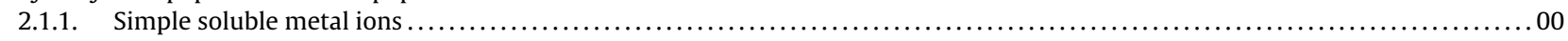

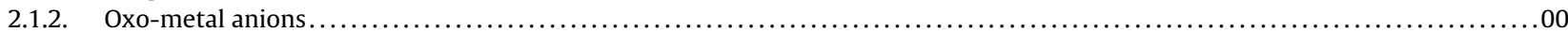

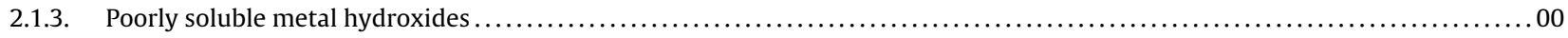

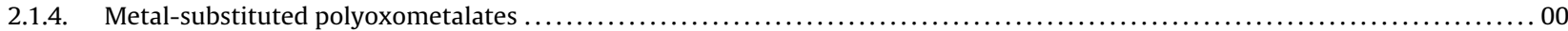

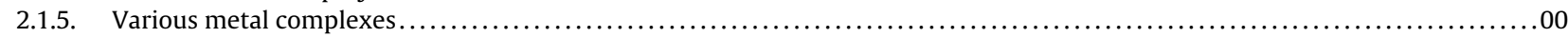

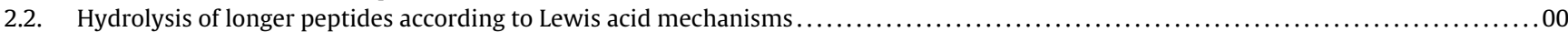

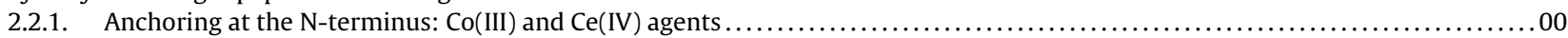

2.2.2. Anchoring at the Cys side chain: molybdocene. $\quad$ An.

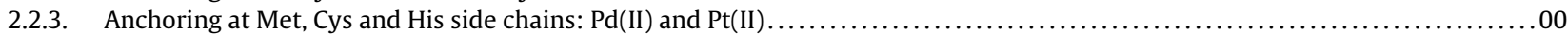

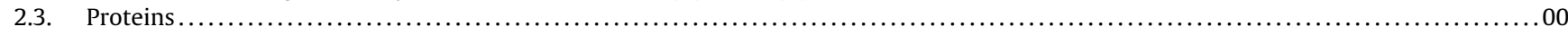

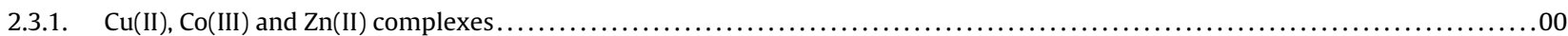

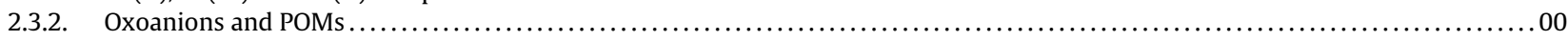

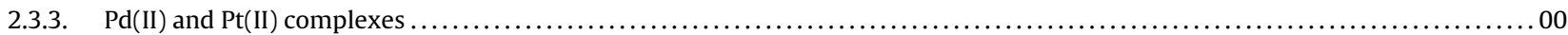

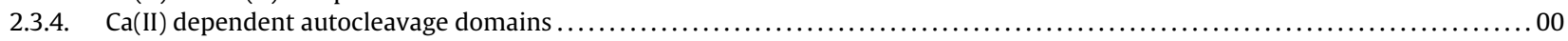

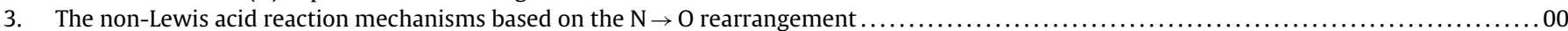

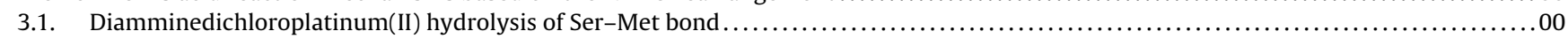

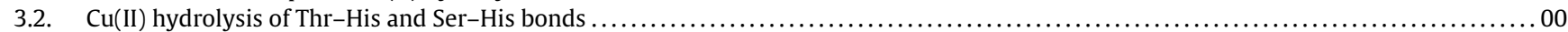

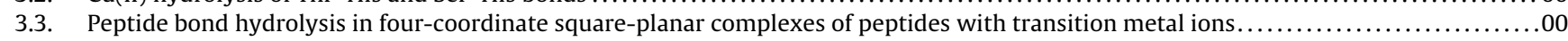

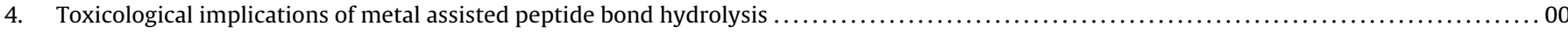

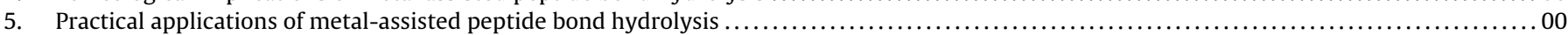

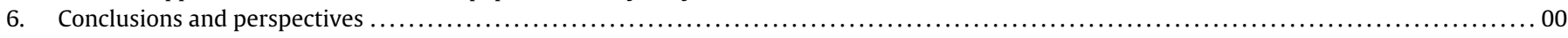

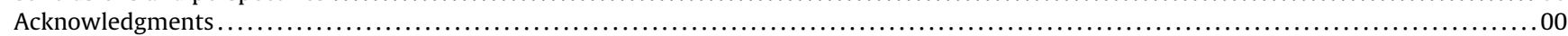

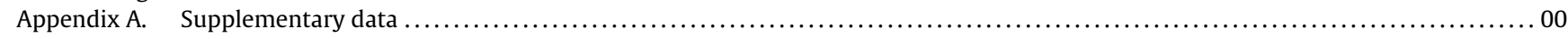

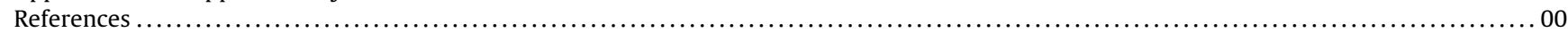

Abbreviations: 1:1 Zr(IV)-Ld POM, Zr(IV)-substituted Lindqvist type polyoxometalate $\left(\mathrm{Me}_{4} \mathrm{~N}_{2}\left[\mathrm{~W}_{5} \mathrm{O}_{18} \mathrm{Zr}\left(\mathrm{H}_{2} \mathrm{O}\right)_{3}\right] ; 1: 2 \mathrm{Ce}(\mathrm{IV})-\mathrm{Kg}\right.$ POM, Ce(IV)-substituted Keggin-type polyoxometalate $\left[\mathrm{Ce}\left(\alpha-\mathrm{PW}_{11} \mathrm{O}_{39}\right)_{2}\right]^{10-} ; 1: 2 \mathrm{Zr}(\mathrm{IV})-\mathrm{Kg}$ POM, Keggin type polyoxometalate $\left(\mathrm{Et}_{2} \mathrm{NH}_{2}\right)_{10}\left[\mathrm{Zr}\left(\mathrm{PW}_{11} \mathrm{O}_{39}\right)_{2}\right] \cdot 7 \mathrm{H}_{2} \mathrm{O} ; 1: 2 \mathrm{Zr}(\mathrm{IV})$-WD POM, Wells-Dawson type polyoxometalate $\mathrm{K}_{15} \mathrm{H}\left[\mathrm{Zr}\left(\alpha_{2}-\mathrm{P}_{2} \mathrm{~W}_{17} \mathrm{O}_{61}\right)_{2}\right]_{25} \mathrm{H}_{2} \mathrm{O} ; 2: 2 \mathrm{Zr}(\mathrm{IV})-\mathrm{Kg}$ POM, Keggin type polyoxometalate $\left(\mathrm{Et}_{2} \mathrm{NH}_{2}\right)_{8}\left[\left\{\alpha-\mathrm{PW}_{11} \mathrm{O}_{39} \mathrm{Zr}-(\mu-\mathrm{OH})\left(\mathrm{H}_{2} \mathrm{O}\right)\right\}_{2}\right] \cdot 7 \mathrm{H}_{2} \mathrm{O} ; 2: 2 \mathrm{Zr}(\mathrm{IV})-\mathrm{Ld} \mathrm{POM}$, Lindqvist-type polyoxometalate $\left(n \mathrm{Bu}_{4} \mathrm{~N}\right)_{6}\left[\left\{\mathrm{~W}_{5} \mathrm{O}_{18} \mathrm{Zr}\left(\mu-\mathrm{OH}_{2}\right)\right\}\right] \cdot 2 \mathrm{H}_{2} \mathrm{O} ; 4: 2 \mathrm{Zr}(\mathrm{IV})-\mathrm{WD}$ POM, tetrazirconium(IV)-substituted Wells-Dawson polyoxometalate, $\mathrm{Na}_{14}\left[\mathrm{Zr}_{4}\left(\mathrm{P}_{2} \mathrm{~W}_{16} \mathrm{O}_{59}\right)_{2}\left(\mu_{3}-\right.\right.$ $\left.\mathrm{O})_{2}(\mathrm{OH})_{2}\left(\mathrm{H}_{2} \mathrm{O}\right)_{4}\right] \cdot 57 \mathrm{H}_{2} \mathrm{O}$; AAT, human $\alpha$-1-antitrypsin; ATCUN/NTS, square planar complexes of peptides or proteins containing the N-terminal R1a-R2a-His sequence; BSA, bovine serum albumin; CoPA, pentaammineaquacobalt(III); COPD, chronic obstructive pulmonary disease; CoTA, tetraamminediaquacobalt(III); $\mathrm{Cp}, \eta^{5}$-cyclopentadienyl; $\left.\mathrm{Cu}[9] \mathrm{aneN}_{3}\right) \mathrm{Cl}_{2}, 1,4,7$-triazacyclononane dichloride; Cyc, cyclen; DFT, density functional theory; dtco-3-OH, dithiacyclooctan-3-ol; EDTA, ethylenediaminetetraacetic acid; en, ethylenediamine; FRET, fluorescence resonance energy transfer; Gly-pNA, glycine- $p$-nitroanilide; GSH, reduced glutathione; GSMe, S-methylglutathione; $\mathrm{H}_{3}$ bcmga, bis$N, N$-carboxymethyl-L-glutamic acid; $\mathrm{H}_{3}$ bcmpa, bis- $N, N$-carboxymethyl-L-phenylalanine; HEPES, 4-(2-hydroxyethyl)-1-piperazineethanesulfonic acid; HEWL, hen-egg-white lysozyme; h-IAPP, human islet amyloid polypeptide; $\mathrm{HL}^{1}$, 2-[(bis(pyridylmethyl)amino)methyl]-4-methyl-6-formylphenol; HSA, human serum albumin; $\mathrm{H}(\mathrm{tdp}), 2-[(2-(2-$ hydroxyethylamino)ethylimino)methyl]phenol; IP, intermediate product; L, 2-[bis(2-aminoethyl)amino]ethanol; MALDI-TOF, matrix-assisted laser desorption/ionization time-of-flight mass spectrometry; Mb, horse heart myoglobin; MIIA domain, metal ion-inducible autocleavage domain; PNA, peptide nucleic acid; POMs, polyoxometalates; PS, polystyrene; pz, pyrazine; SPI-2, serine protease inhibitor 2; tren, triaminotriethylamine; trien, triethylenetetraamine; tmp, 3,4,7,8-tetramethyl-1,10-phenanthroline; Tris, tris(hydroxymethyl)aminomethane.

* Corresponding author. Tel.: +48 22592 2346; fax: +48 226584636.

E-mail address: wbal@ibb.waw.pl (W. Bal). 


\section{A R T I C L E I N F O}

\section{Article history:}

Received 15 January 2016

Received in revised form 24 February 2016

Accepted 25 February 2016

Available online $\mathrm{xxx}$

\section{Keywords:}

Peptide bond hydrolysis

Metal ions

Lewis acid

$\mathrm{N} \rightarrow \mathrm{O}$ acyl rearrangement

\begin{abstract}
A B S T R A C T
Metal-assisted hydrolysis of peptide bond is a promising alternative for enzymatic cleavage of proteins with prospective applications in biochemistry and bioengineering. Many metal ions and complexes have been tested for such reactivity with a number of targets, from dipeptides through oligopeptides through proteins. The majority of reaction mechanisms reported so far is based on the Lewis acidity of a given metal ion. In the alternative hydrolysis reaction the metal ion, $\mathrm{Cu}(\mathrm{II}), \mathrm{Ni}(\mathrm{II})$ or $\mathrm{Pd}(\mathrm{II})$, plays a structural role by forming a square planar complex with Ser/Thr-His or Ser/Thr-Xaa-His sequence, which enables a $\mathrm{N} \rightarrow \mathrm{O}$ rearrangement of the acyl moiety in the peptide bond downstream from the Ser/Thr residue. Both Lewis acid and $\mathrm{N} \rightarrow \mathrm{O}$ acyl rearrangement reaction types are discussed in detail, including molecular mechanisms, the chemical character of hydrolytic agents, reaction conditions, and the origins of differences between the results obtained for peptide and protein models. Toxicological implications and practical applications of metal assisted peptide bond hydrolysis are also presented, with a focus on the $\mathrm{Ni}(\mathrm{II})$ assisted $\mathrm{N} \rightarrow \mathrm{O}$ acyl rearrangement in Ser/Thr-Xaa-His sequences.
\end{abstract}

(C) 2016 Elsevier B.V. All rights reserved.

\section{Introduction}

Peptide bond, the focus of this review, is one of the most important linkages in the realm of biomolecules. Its main function is to connect amino acid residues, forming peptide and protein chains. In Nature, the peptide bond is formed by the condensation reaction between the $\alpha$-carboxylic group of one amino acid and the $\alpha$-amino group of another one, resulting in the loss of a water molecule. In the cells the reaction is catalyzed by ribosome, a large protein/RNA structure which accelerates it by a factor of $10^{7}[1,2]$. One may say that the creative limitedness of protein structures results directly from properties of the peptide bond, especially from the partial double-bond nature of the $\mathrm{C}-\mathrm{N}$ bond which imposes planarity in this structure, as shown in Fig. 1 [3]. It is however important to mention that in the reality of protein structures significant deviations from the planarity may occur for individual bonds, with significant consequences for their stability [4].

The peptide bond is very stable in water solution under physiological condition. Its half-life is estimated at 350-600 years at $25^{\circ} \mathrm{C}$ and neutral $\mathrm{pH}$ [5]. This remarkable kinetic stability is required for its function, but presents a challenge when there is a physiological need to break it. There are three general types of peptide bond cleavage mechanisms: oxidative, photooxidative and hydrolytic [6-9]. The first two introduce covalent modifications into the cleaved moiety, being thus irreversible. They are also difficult to control, often causing "collateral damage" of covalent modifications of other functional groups in proteins. Only the hydrolysis reaction, reciprocal to the condensation reaction, can cleave the peptide bond by restoring the carboxylic and amine functional groups. This chemical strategy was adopted by living organisms, where several classes of peptidases, enzymes hydrolyzing the peptide bonds, evolved.

Enzymes catalyze peptide bond hydrolysis using two general strategies: either utilizing a one-step process in which the activated water molecule is a nucleophile attacking the amide bond, or in a two-step process with the participation of a nucleophilic residue. According to the former mechanism, a water molecule is activated by an aspartic acid residue or a metal ion, usually $\mathrm{Zn}(\mathrm{II})$. In the

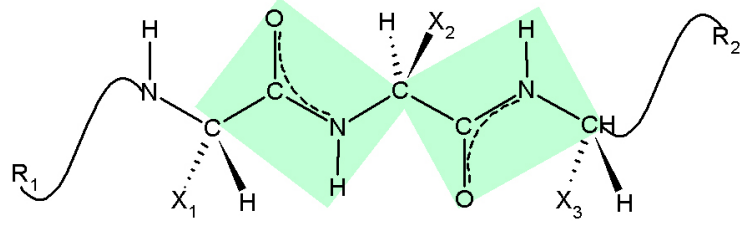

Fig. 1. The structure of the peptide bond in the context of the peptide chain. Planar fragments are marked with gray rectangles. The common trans-conformation is shown. second case, a Ser, Thr, or Cys residue performs a nucleophilic attack, which results in the covalent binding of C-terminal part of the processed protein to the enzyme. The $\mathrm{N}$-terminal part of the substrate is released simultaneously. In the second step of this reaction type the acyl-enzyme intermediate is hydrolyzed finally by an activated water molecule $[10,11]$.

The proteolytic enzymes have different types of specificities, depending on their function. Some, like those responsible for posttranslational processing of proteins or peptides, e.g., Angiotensin Converting Enzyme, are highly sequence specific [12]. Others, like Proteinase K, cleave all peptide bonds non-specifically [13]. This function can be reproduced chemically in a simple procedure of acid digestion at elevated temperatures [14]. Thus, current efforts in providing chemical tools for peptide bond hydrolysis focus on reactions that provide at least moderate sequence specificity. This goal cannot be really provided by simple non-enzymatic chemical agents, notably cyanogen bromide, which not only have poor specificity, but also usually require harsh reaction conditions, leading to unwanted side reactions $[15,16]$.

Autocatalytic peptide bond hydrolysis mechanisms evolved for posttranslational modifications of proteins separately from enzymatic mechanisms. The most important of these mechanisms are $\mathrm{N} \rightarrow \mathrm{O}$ and $\mathrm{N} \rightarrow \mathrm{S}$ acyl transfer reactions, utilizing serine, threonine and cysteine residues. Under particular steric conditions enforced by specific protein domain fold, the Ser/Thr hydroxyl or Cys thiol group can attack the carbonyl carbon of the preceding amide bond results in an (thio)ester intermediate. The (thio)ester then splits into two separate molecules. At physiological conditions this reaction is not favored, but an acidification or an alkalization shifts the reaction equilibrium toward the products. Proteins which undergo such autoproteolysis facilitate the process by enhancing the deprotonation of catalytic $-\mathrm{OH} /-\mathrm{SH}$ group, the amino group protonation and the destabilization of the hydrolyzed peptide bond by structural changes [17]. As mentioned above, the autoproteolysis process, while very clean in terms of side-reactions, requires large protein domains and cannot be easily used to cleave bonds in other proteins.

These circumstances encouraged the search for novel agents for peptide bond hydrolysis in the field of metal ion chemistry. The purpose of this review is to present the current stage of this research area and to sketch some perspectives for its further development. Some approaches described below are aimed to mimic or paraphrase metalloproteases, while other look for novel reactivities. Three general reaction mechanisms depicted in Fig. 2 are exploited in these studies.

Two of these mechanisms are based on Lewis acid properties of given metal ions. In this paradigm the metal ion can (i) activate a water molecule or (ii) activate/destabilize the peptide bond by engaging its carbonyl oxygen. These two mechanisms often occur 
(i)

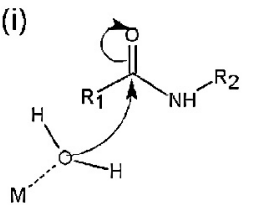

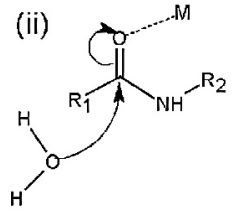

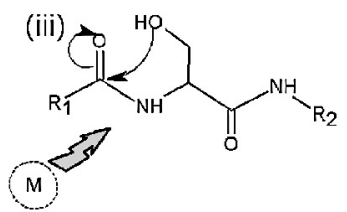

Fig. 2. Three general mechanisms of metal-assisted peptide bond hydrolysis: (i) activation of a water molecule by metal ion $\mathrm{M}$; (ii) polarization of carbonyl group by interaction of a metal ion with the amide oxygen; and (iii) $\mathrm{N} \rightarrow \mathrm{O}$ acyl rearrangement in sequences containing hydroxyl or carboxyl group in side-chain residues.

simultaneously, or are difficult to distinguish. In principle, they can occur for any peptide bond, although as detailed below, a significant degree of sequence specificity can be achieved by additional interactions. The third mechanism (iii) is based on the acyl shift rearrangement, which has not been identified in metalloproteases, but is employed in Nature in Ser/Thr/Cys proteases and the intein protein self-cleavage process. In contrast with mechanisms (i) and (ii), mechanism (iii) is explicitly sequence dependent, requiring the presence of a hydroxyl, thiol, or carboxyl group in the side-chain of the residue flanking the hydrolyzed bond. Nevertheless, also mechanism (iii) appears to coincide with mechanisms (i) and (ii) in some cases, adding complexity to the presented reactions.

A number of metal ions and their complexes were demonstrated to promote peptide bond hydrolysis under a large variety of reaction conditions, and against various substrates. These metal ions include (in the alphabetical order) $\mathrm{Cd}(\mathrm{II}), \mathrm{Ce}(\mathrm{III}), \mathrm{Ce}(\mathrm{IV}), \mathrm{Co}(\mathrm{III})$, $\mathrm{Cr}(\mathrm{VI}), \mathrm{Cu}(\mathrm{II}), \mathrm{Eu}(\mathrm{II}), \mathrm{Hf}(\mathrm{IV}), \mathrm{Mo}(\mathrm{IV}), \mathrm{Mo}(\mathrm{VI}), \mathrm{Ni}(\mathrm{II}), \mathrm{Pd}(\mathrm{II}), \mathrm{Pr}(\mathrm{II}), \mathrm{Pt}(\mathrm{II})$, $\mathrm{V}(\mathrm{V}), \mathrm{W}(\mathrm{IV}), \mathrm{W}(\mathrm{VI}), \mathrm{Zn}(\mathrm{II})$, and $\mathrm{Zr}(\mathrm{IV})$. Below we describe the current state of this research field according to the reaction mechanism and substrate type, followed by a short account of toxicological and aspects of selected reactions associated with their biotechnological applications.

\section{Hydrolysis according to Lewis acid mechanisms}

A large number of studies were performed for metal ions interacting effectively with oxygen ligands, and thus able to maintain reaction mechanisms (i) and (ii) presented in Fig. 2. The bulk of studies were performed for dipeptides, with some research on longer peptides and proteins. They are described below in this order. The perfect metal-based Lewis acid hydrolytic agents should not only prefer to interact with oxygen ligands as mentioned above, but should also be able to form complexes with high coordination numbers. Further requirements include fast ligand exchange and a lack of redox activity that could lead to side processes along with the hydrolysis reaction.

\subsection{Hydrolysis of peptide bond in dipeptides}

Dipeptide is the simplest possible model for studying the metalassisted peptide bond hydrolysis. Having only a single reaction site, dipeptides enable very precise studies of the reaction mechanism, facilitating analysis of experimental data and adding certainty to their interpretation. Comparing the results for different dipeptides one can recognize the initial preferences of metal cleavage agents toward the residues composing the bond. This leads to preliminary estimates for sequence specificities of given agents, and helps in selecting the best reaction conditions.

Gly-Gly and Gly-Ser are the two most popular dipeptides used in metal-assisted hydrolysis studies. The reaction parameters determined for the most effective and important hydrolytic agents are listed in Table 1. The efficacy of hydrolysis is presented as the rate constant or the conversion degree, depending on the data presentation in original papers. The most important reaction conditions ( $\mathrm{pH}$, temperature and agent-to-peptide molar ratio) are also provided.

The metal-based hydrolytic agents can be divided into five groups: simple soluble metal ions, oxo-metal anions, poorly soluble metal hydroxides, metal-substituted polyoxometalates, and various metal complexes which cannot be systematized. They are described in this order in the following section of this review.

\subsubsection{Simple soluble metal ions}

Yashiro and co-workers studied the ability of the number of metal chlorides to cleave dipeptides [18]. Incubation of peptides with almost all metal ions tested significantly increased the amount of hydrolysis products. After a 24-h incubation with Gly-Ser at $\mathrm{pH}$ 7.0 and $70^{\circ} \mathrm{C}$, the highest conversion degree (83\%) was observed for $\mathrm{Zn}(\mathrm{II})$, followed by $\mathrm{Pr}(\mathrm{III})$ (63\%), $\mathrm{Eu}(\mathrm{III})$ (58\%), Ni(II) (52\%), Ce(III) (49\%), and Cd(II) (43\%). The active intermediates were metal complexes formed by the metal ion binding to the N-terminal amino group and the carbonyl (peptide) oxygen. Incubation of Gly-Ser with $\mathrm{Cu}(\mathrm{II})$ did not assist the hydrolysis due to a specific coordination mode of this ion, via the $\mathrm{N}$-terminal amine, the amide nitrogen, and the $\mathrm{C}$-terminal carboxyl group. This mode prevents the peptide bond cleavage due to Lewis acid mechanisms, because the carbonyl oxygen is not engaged by the $\mathrm{Cu}(\mathrm{II})$ ion.

The hydrolysis by Zn(II), Ni(II), and Cd(II) ions was more selective toward Gly-Ser than that for Eu(III), a representative lanthanide metal. The character of the $\mathrm{N}$-terminal residue had a low impact

Table 1

The comparison of metal-assisted hydrolysis of Gly-Ser and Gly-Gly peptide bonds by different Lewis acid metal containing agents.

\begin{tabular}{|c|c|c|c|c|c|c|c|c|}
\hline \multirow[t]{2}{*}{ Agent } & \multirow[t]{2}{*}{$\mathrm{pH} / \mathrm{pD}$} & \multirow[t]{2}{*}{$T\left({ }^{\circ} \mathrm{C}\right)$} & \multirow[t]{2}{*}{$\begin{array}{l}\text { Agent:peptide } \\
\text { molar ratio }\end{array}$} & \multicolumn{2}{|c|}{ Rate constant $\left(\mathrm{s}^{-1}\right)$} & \multicolumn{2}{|c|}{$\begin{array}{l}\text { Conversion degree } \\
\text { (time/h) }\end{array}$} & \multirow[t]{2}{*}{ Refs. } \\
\hline & & & & Gly-Ser & Gly-Gly & Gly-Ser & Gly-Gly & \\
\hline $\mathrm{ZnCl}_{2}$ & 7.0 & 70 & $1: 1$ & n.d. & n.d. & $83 \%(24)$ & $6 \%(24)$ & [18] \\
\hline $\mathrm{MoO}_{4}^{2-}$ & 7.0 & 60 & $60: 1$ & $5.9 \times 10^{-6}$ & n.d. & $68 \%(60)$ & $4 \%(60)$ & [19] \\
\hline $\mathrm{CrO}_{4}^{2-}$ & 7.0 & 60 & $60: 1$ & $4.4 \times 10^{-7}$ & n.d. & n.d. & n.d. & [19] \\
\hline $\mathrm{WO}_{4}^{2-}$ & 7.0 & 60 & $60: 1$ & $6.5 \times 10^{-7}$ & n.d. & n.d. & n.d. & [19] \\
\hline \multirow{2}{*}{$\mathrm{VO}_{4}^{2-}$} & 7.4 & 60 & $10: 1$ & $1.33 \times 10^{-6}$ & n.d. & $52 \%(140)$ & n.d. & [20] \\
\hline & 7.4 & 37 & $10: 1$ & $8.9 \times 10^{-8}$ & n.d. & n.d. & n.d. & [20] \\
\hline $\mathrm{Ce}\left(\mathrm{NH}_{4}\right)_{2}\left(\mathrm{NO}_{3}\right)_{6}$ & 7.0 & 50 & $1: 1$ & $6.4 \times 10^{-5}$ & $7.7 \times 10^{-5}$ & n.d. & n.d. & [23] \\
\hline $1: 2 \mathrm{Ce}(\mathrm{IV})-\mathrm{Kg}$ POM & 7.4 & 37 & $10: 1$ & $7.5 \times 10^{-7}$ & $2.8 \times 10^{-8}$ & n.d. & n.d. & [32] \\
\hline $\mathrm{ZrCl}_{4}$ & $7.1-7.2$ & 60 & $5: 1$ & n.d. & n.d. & $28 \%(20)$ & $26 \%(20)$ & [24] \\
\hline $\mathrm{ZrCl}_{4}+4,13$-diaza-18-crown-6 & $7.0-7.2$ & 60 & $5: 1$ & n.d. & n.d. & $88 \%(20)$ & $90 \%(20)$ & [24] \\
\hline 1:2 Zr(IV)-WD POM & 5.0 & 60 & $1: 1$ & $3.5 \times 10^{-6}$ & $1.5 \times 10^{-6}$ & n.d. & n.d. & {$[27,28]$} \\
\hline $4: 2$ Zr(IV)-WD POM & 7.4 & 60 & $6: 1$ & $2.3 \times 10^{-6}$ & $4.7 \times 10^{-7}$ & n.d. & n.d. & [31] \\
\hline $1: 2 \mathrm{Zr}(\mathrm{IV})-\mathrm{Ld}$ POM & 7.4 & 60 & $1: 1$ & $1.5 \times 10^{-6}$ & $1.9 \times 10^{-7}$ & n.d. & n.d. & [29] \\
\hline 2:2 Zr(IV)-Kg POM & 5.4 & 60 & $1: 1$ & $6.33 \times 10^{-6}$ & $4.44 \times 10^{-7}$ & n.d. & n.d. & [30] \\
\hline
\end{tabular}

POM denotes polyoxometallate; n.d. denotes a parameter not determined. 


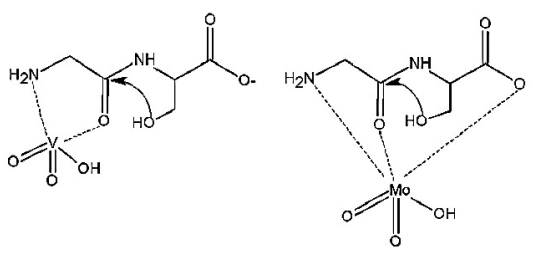

C

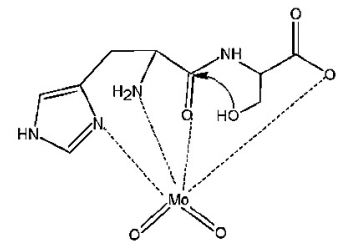

Fig. 3. The proposed mechanism of hydrolysis Gly-Ser (A, B) and His-Ser (C) dipeptides by $\mathrm{VO}_{4}^{2-}(\mathrm{A})$ and $\mathrm{MoO}_{4}^{2-}(\mathrm{B}, \mathrm{C})[19,20]$.

on the hydrolysis by these metal ions. Conversion degrees comparable to Gly-Ser or even higher were observed for Phe-Ser (91\%), Leu-Ser (81\%), and Pro-Ser (80\%) after $24 \mathrm{~h}$, at $\mathrm{pH} 7.0$ and $70^{\circ} \mathrm{C}$ for $\mathrm{Zn}(\mathrm{II})$-assisted hydrolysis. The decrease in temperature by $20^{\circ} \mathrm{C}$ resulted in an almost four-fold reduction of the yield of $\mathrm{Zn}(\mathrm{II})-$ assisted Gly-Ser hydrolysis [18].

\subsubsection{Oxo-metal anions}

The second group of hydrolytic agents are oxo-metal anions, homologous agents widely used in catalytic reactions. Parac-Vogt and co-workers proved that $\mathrm{MoO}_{4}^{2-}, \mathrm{WO}_{4}^{2-}, \mathrm{CrO}_{4}^{2-}$, and $\mathrm{VO}_{4}^{2-}$ are able to cleave peptide bond in various dipeptides $[19,20]$. The Xaa-Ser sequence was also more prone to hydrolysis than other tested ones. The conversion degree for Gly-Ser was more than 22 and 17 times higher than for Ser-Gly for $\mathrm{MoO}_{4}^{2-}$ and $\mathrm{VO}_{4}^{2-}$, respectively under the same reaction conditions and incubation time, $(\mathrm{pD}$ $7.0,60^{\circ} \mathrm{C}$ and $60 \mathrm{~h}$ for $\mathrm{MoO}_{4}^{2-}$ and $\mathrm{pD} 7.4,60^{\circ} \mathrm{C}$ and $140 \mathrm{~h}$ for $\mathrm{VO}_{4}^{2-}$ ). Among all the oxyanions studied, $\mathrm{MO}_{4}^{2-}$, where $\mathrm{M}$ was $\mathrm{Mo}(\mathrm{VI})$, $\mathrm{Cr}(\mathrm{VI}), \mathrm{W}(\mathrm{VI})$, and $\mathrm{V}(\mathrm{V}), \mathrm{MoO}_{4}^{2-}$ was the most effective one followed by $\mathrm{VO}_{4}^{3-}, \mathrm{WO}_{4}^{2-}$, and $\mathrm{CrO}_{4}^{2-}$ (see Table 1 for details). The more than four times lower rate constant for $\mathrm{VO}_{4}^{3-}$ compared to $\mathrm{MoO}_{4}^{2-}$ may result from the differences in the coordination of these species to Gly-Ser (Fig. 3A and B).

In hydrolytically active complexes, vanadate can bind to Gly-Ser by the amine nitrogen and carbonyl oxygen, while $\mathrm{MoO}_{4}^{2-}$ also binds to the carboxyl oxygen. This interaction adds stability to the reactive complex, resulting in a faster hydrolysis. In support of this concept, the presence of a coordinating His side-chain, in the His-Ser dipeptide caused an almost two-fold acceleration of the hydrolysis by $\mathrm{MoO}_{4}^{2-}$ compared to Gly-Ser (Fig. 3 C).

The proposed reason for the lower constant rate for chromate is a smaller size of $\mathrm{CrO}_{4}^{2-}$ compared to $\mathrm{MoO}_{4}^{2-}$, resulting in a higher solvation degree of $\mathrm{CrO}_{4}^{2-}$, impeding its coordination to the peptide [19]. The sizes of ionic radii of $\mathrm{MoO}_{4}^{2-}$ and $\mathrm{WO}_{4}^{2-}$ are similar, resulting in the formation of complexes with similar binding constants, as for EDTA [21]. However, the tungstate forms more labile chelates than molybdate with respect to the individual metal-ligand bonds, which is a likely cause for a lower rate constant for Gly-Ser hydrolysis by $\mathrm{WO}_{4}^{2-}[19,21,22]$.

The pD dependence of observed rate constant $k_{\text {obs }}$ for hydrolysis of dipeptides by oxo-metal anions has a bell-shaped profile, with the maximum at $\mathrm{pD}$ about 7.0 and 7.4 for the hydrolysis of Gly-Ser by $\mathrm{MoO}_{4}^{2-}$ and $\mathrm{VO}_{4}^{3-}$, respectively (the reactions were investigated by NMR in $\mathrm{D}_{2} \mathrm{O}$ solutions). The observed optimum is associated with the $\mathrm{pD}$ distribution of oxo-metal anion forms. Dissolved oxo-metal anions tend to form polyoxyanions, whereas only the monomeric species are hydrolytically active. For oxomolybdates the oligomeric $\left[\mathrm{Mo}_{7} \mathrm{O}_{24}\right]^{6-}$ and $\left[\mathrm{Mo}_{8} \mathrm{O}_{26}\right]^{4-}$ species predominate at acidic conditions. The reaction is fastest about $\mathrm{pD} 7.0$, when the monomeric $\left[\mathrm{MoO}_{4}\right]^{2-}$ anion becomes the only observed oxomolybdate species. A similar trend was observed for vanadates. At low pD values, the decavanadate was the major observed species, while at neutral $\mathrm{pD}$ the mixture of mono- di-, tetra-, and pentavanadate existed in the solution. Further increase of pD shifted the equilibrium in favor of the monomeric form $[19,20]$.

Despite the higher amount of hydrolytically active monomeric anions under alkaline conditions, the observed rate constant was lower. This phenomenon was explained by the possible coordination of the metal species by the amide nitrogen. The metal ion bound to the amide nitrogen has significantly weaker polarizing properties than the proton it replaced, thus making the amide carbonyl carbon a less preferred target for the nucleophilic attack $[19,20]$.

The hydrolytic nature of the described reaction was also confirmed by NMR measurements, which did not detect any paramagnetic $\mathrm{Mo}(\mathrm{V})$ and $\mathrm{V}(\mathrm{IV})$ species that should be formed if $\mathrm{MoO}_{4}^{2-}$ and $\mathrm{VO}_{4}^{3-}$ were to oxidize the dipeptides $[19,20]$.

\subsubsection{Poorly soluble metal hydroxides}

$\mathrm{Ce}(\mathrm{IV})$ and $\mathrm{Zr}(\mathrm{IV})$ could be perfect peptide hydrolytic agents due to their oxophilic properties, high +4 oxidation state, ability to form complexes with high coordination numbers, and a fast-ligand exchange kinetics. However, at neutral $\mathrm{pH}$ the $\mathrm{Ce}(\mathrm{IV})$ and $\mathrm{Zr}(\mathrm{IV})$ compounds usually yield insoluble hydroxide species forming gels and precipitates upon dissolution. Despite of the heterogeneous nature of such solid state compounds, Komiyama and Grant groups tested their ability to hydrolyze dipeptides by adding $\mathrm{Ce}(\mathrm{IV})$ or $\mathrm{Zr}(\mathrm{IV})$ salts to their solutions $[23,24]$. $\mathrm{Ce}\left(\mathrm{NH}_{4}\right)_{2}\left(\mathrm{NO}_{3}\right)_{6}$ was the most effective hydrolytic agent among the studied precursors $\left(\mathrm{Ce}\left(\mathrm{NH}_{4}\right)_{2}\left(\mathrm{SO}_{4}\right)_{4}, \mathrm{Ce}\left(\mathrm{SO}_{4}\right)_{2}\right.$, and $\left.\mathrm{Ce}(\mathrm{OH})_{4}\right)$. Despite well-known properties of $\mathrm{Ce}(\mathrm{IV})$ as oxidant, no oxidative cleavage products were found by NMR. The hydrolysis in the presence of $\mathrm{Ce}\left(\mathrm{NH}_{4}\right)_{2}\left(\mathrm{NO}_{3}\right)_{6} \cdot \mathrm{H}_{2} \mathrm{O}$ was the fastest for Phe-Gly, Ala-Phe, and Gly-Phe, with the rate constants of $0.97-1.14 \times 10^{-4} \mathrm{~s}^{-1}$ at $\mathrm{pH} 7.0$ and $50^{\circ} \mathrm{C}$. For Xaa-Phe dipeptides, the rate constant decreased with the increase of the non-coordinating Xaa residue side chain volume. Such dependence was not observed for Gly-Xaa dipeptides. The $\mathrm{Ce}(\mathrm{IV})$ ion complexed to the peptides via the amino group, the carboxylate oxygen, and the carbonyl oxygen [23]. The decrease in the extent of Ce(IV) precipitation was achieved by the cyclodextrin application. The mixture of the peptide, $\mathrm{Ce}(\mathrm{IV})$ and $\gamma$ cyclodextrin was homogenous in a water solution, no precipitation was observed. After $24 \mathrm{~h}$ at $\mathrm{pH} 8.0$ and $60^{\circ} \mathrm{C}, 39$ and $36 \%$ of the most susceptible dipeptides, Gly-Phe and Phe-Gly, were cleaved by $\mathrm{Ce}(\mathrm{IV})$ in the $\gamma$-cyclodextrin presence [25].

Despite the precipitation of zirconium hydroxides, also $\mathrm{ZrCl}_{4}$ was an effective hydrolytic agent toward a number of dipeptides. After $20 \mathrm{~h}$ at $\mathrm{pH} 6.9-7.4$ and $60^{\circ} \mathrm{C}$, the hydrolysis degree ranged from $4 \%$ for Gly-Met to $42 \%$ for Gly-Gly [24]. The conversion degree increased dramatically after the addition of an azacrown ether, 4,13-diaza-18-crown-6. The effect was most striking for Ser-Gly (from 7\% to 91\%) and negatively charged dipeptides such as Gly-Glu (from $10 \%$ to $97 \%$ ), Asp-Gly/Gly-Asp (from $19 / 30 \%$ to $85 / 87 \%$ ), but was also significant for Gly-Gly (from $42 \%$ to $90 \%$ ) and Gly-Ser (from $28 \%$ to $88 \%$ ). No hydrolysis was observed in control experiments with peptides and the azacrown ether without $\mathrm{Zr}(\mathrm{IV})$. The addition of azacrown ether to the $\mathrm{Zr}$ (IV) containing solution also led to the hydrolysis of the $\mathrm{N}$ - and C-terminally blocked peptide Ac-Gly-Gly-OMe, up to $26 \%$, while almost no cleavage was observed in the absence of the macrocyclic chelator. Although the azacrown ether increased the $\mathrm{Zr}(\mathrm{IV})$ precipitation, the hydrolysis was accelerated. The application of Tris decreased the amount of $\mathrm{Zr}(\mathrm{IV})$ precipitate, but the hydrolysis rate also decreased [24].

The only by-product of the hydrolysis reaction described above was a cyclic dipeptide dimer (diketopiperazine) formed by a condensation reaction between the terminal carboxylate and amine groups. Ce(IV) did not promote this cyclization reaction in contrast to other tested metals, e.g., $\mathrm{Zr}(\mathrm{IV})$, and Hf(IV) [23]. 
A

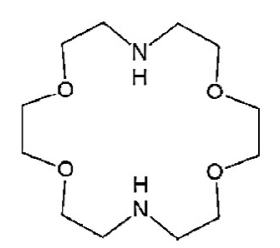
B

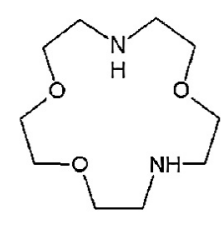

$\mathrm{C}$

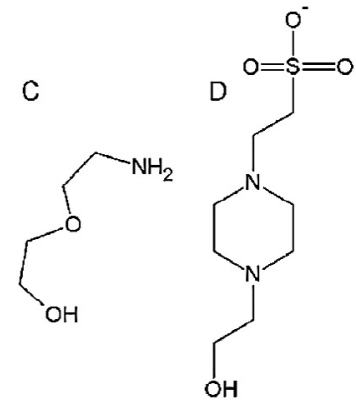

Fig. 4. Compounds that accelerated the $\mathrm{Zr}(\mathrm{IV})$-assisted hydrolysis of Gly-Gly peptide most effectively: (A) 4,13-diaza-18-crown-6; (B) 1,4,10trioxa-7,13-diazacyclopentadecane; (C) 2-(2-aminoethoxy)-ethanol and (D) 4-(2-hydroxyethyl)-1-piperazineethanesulfonic acid (HEPES) [26].

In the a study building on the results described above, Kassai and Grant used 17 ligands to enhance the $\mathrm{Zr}(\mathrm{IV})$-assisted peptide bond hydrolysis, including macrocyclic crown ligands, but also HEPES and Tris and their derivatives. The most effective ones, presented in Fig. 4, were: 4,13-diaza-18-crown-6; 1,4,10-trioxa-7,13diazacyclopentadecane; 2-(2-aminoethoxy)-ethanol and HEPES [26].

Both cyclic and linear compounds increased the hydrolysis rate, but the cyclic ones were the most productive. This effect was attributed to the ordering of the coordination sphere around the $\mathrm{Zr}(\mathrm{IV})$ ion. The equatorial sites would be occupied by the macrocyclic chelator, thus enhancing an interaction of free axial coordination sites on the $\mathrm{Zr}(\mathrm{IV})$ ion with the hydroxide nucleophile and the dipeptide amide oxygen.

The significant level of precipitation was observed for almost all ligands studied, except Tris and 2,2',2' -nitrilotrisethanol. In parallel with the reduction of the precipitate amount, the hydrolysis rate for these ligands also decreased [26].

\subsubsection{Metal-substituted polyoxometalates}

Oxo-metal compounds described above as hydrolytically active as monomeric species are also used in metal-based hydrolysis in their regular oligomeric forms, polyoxymetalates (POMs). A POM is a kind of a scaffold, in which one or more atoms can be replaced by a selected metal center, changing properties POM coordination properties. POMs were applied to Zr(IV)- and Ce(IV)-assisted peptide bond hydrolysis as compounds used to obtain homogenous solution of these metals after an incorporation of $\mathrm{Zr}(\mathrm{IV})$ and $\mathrm{Ce}(\mathrm{IV})$ ions into the POM structure.

Studies on Wells-Dawson type polyoxometalates $\mathrm{K}_{15} \mathrm{H}\left[\mathrm{M}\left(\alpha_{2}-\right.\right.$ $\left.\left.\mathrm{P}_{2} \mathrm{~W}_{17} \mathrm{O}_{61}\right)_{2}\right]_{25} \mathrm{H}_{2} \mathrm{O}$, revealed that $\mathrm{Zr}(\mathrm{IV})$ and $\mathrm{Hf}(\mathrm{IV})$ species showed the highest hydrolytic activity toward the Gly-Gly dipeptide [27]. A lack or significant reduction of activity of other compounds has several reasons. It is due to the limited number of metal coordination sites which can be available for peptide binding after the incorporation into the POM structure (Mn(III), Fe(III), Co(II), Ni(II), and $\mathrm{Cu}(\mathrm{III})$ ). It can also result from a decrease of their Lewis acidity or the dimer formation (Y(III), $\mathrm{La}(\mathrm{III}), \mathrm{Eu}(\mathrm{III})$, and $\mathrm{Yb}(\mathrm{IIII})$ ). The half time for Gly-Gly hydrolysis by $\mathrm{K}_{15} \mathrm{H}\left[\mathrm{Zr}\left(\alpha_{2}-\mathrm{P}_{2} \mathrm{~W}_{17} \mathrm{O}_{61}\right)_{2}\right]_{25} \mathrm{H}_{2} \mathrm{O}$ ( $1: 2 \mathrm{Zr}$-WD POM) was 5 days at pD 5.0 and $60^{\circ} \mathrm{C}$. The $\mathrm{Zr}$ (IV) precipitation did not occur in the POM presence, but cyclization of Gly-Gly (up to $7.5 \%$ ) was observed. The reaction rate peaked at $\mathrm{pD}$ 5.0 , probably as a consequence of predomination of a hydrolytically active $1: 1 \mathrm{Zr}(\mathrm{IV})$ :POM at acidic conditions. The $\mathrm{Zr}(\mathrm{IV})$ ion interacts with Gly-Gly via the amine nitrogen and the amide oxygen. This activates the peptide bond for a nucleophilic attack of the coordinated or solvent-derived water molecule. This species is superseded at higher $\mathrm{pD}$ values by a complex including the coordination of $\mathrm{Zr}(\mathrm{IV})$ to the amide nitrogen. The experiments on other Gly-Xaa dipeptides showed preferences expected for the participation of $\mathrm{N} \rightarrow \mathrm{O}$ rearrangement in the hydrolysis mechanism [28]. The Gly-Ser hydrolysis was more than two times faster than Gly-Gly. The rate constant decreased with the increase of the aliphatic/aromatic side chain volume. The negatively charged Gly-Glu dipeptide was less susceptible to hydrolysis because the coordination via the $\mathrm{C}$-terminal and side chain carboxyl groups prevented the polarization of the amide bond, necessary for the nucleophilic attack. The presence of positively charged amino acids supports the $\mathrm{Zr}(\mathrm{IV})$-assisted hydrolysis due to a secondary interaction between them and the negatively charged POM surface at $\mathrm{pD}$ 5.0 [28].

The usage of $\mathrm{Zr}(\mathrm{IV})$-substituted Lindqvist type POMs $\left(\mathrm{Me}_{4} \mathrm{~N}\right)_{2}\left[\mathrm{~W}_{5} \mathrm{O}_{18} \mathrm{Zr}\left(\mathrm{H}_{2} \mathrm{O}\right)_{3}\right](1: 1 \mathrm{Zr}(\mathrm{IV})$-Ld POM) resulted in the shift of the $\mathrm{pD}$ dependence maximum of the rate constant to 7.5 from 5.0, observed for the previously described $1: 2 \mathrm{Zr}$ (IV)-WD POM. The $\mathrm{Zr}(\mathrm{IV})$ precipitation was also inhibited. The coordination of the fastest His-Ser peptide to $\operatorname{Zr}(\mathrm{IV})$ via the imidazole nitrogen, the amine nitrogen and the amide oxygen promoted the hydrolysis. At acidic pD the imidazole nitrogen protonation inhibited the reaction, while at basic $\mathrm{pD}$, the $\mathrm{Zr}(\mathrm{IV})$ binding to the amide nitrogen ceased the polarization of the peptide bond. The rate constant decrease at high $\mathrm{pD}$ could also result from a partial decomposition of $1: 1 \mathrm{Zr}(\mathrm{IV})$-Ld POM into $\left[\mathrm{WO}_{4}\right]^{2-}$ and $\mathrm{Zr}(\mathrm{IV})$ hydroxides. The $\mathrm{Zr}(\mathrm{IV})$-assisted hydrolysis by $1: 1 \mathrm{Zr}(\mathrm{IV})-\mathrm{Ld}$ POM was slower than that observed for $1: 2 \mathrm{Zr}(\mathrm{IV})-\mathrm{WD}$ POM or the $\mathrm{Zr}(\mathrm{IV}$ ) complex of 4,13-diaza-18-crown-6 (by 2 and 20 times, respectively, for Gly-Ser). The hydrolysis in the presence of $1: 1$ $\mathrm{Zr}$ (IV)-Ld POM combines two features which are desirable from the application point of view: the homogenous nature of the reaction mixture (no precipitation) and the highest reaction yield at physiological $\mathrm{pH}$ [29].

Keggin type POMs, $\left(\mathrm{Et}_{2} \mathrm{NH}_{2}\right)_{8}\left[\left\{\alpha-\mathrm{PW}_{11} \mathrm{O}_{39} \mathrm{Zr}-(\mu-\mathrm{OH})\left(\mathrm{H}_{2} \mathrm{O}\right)\right\}_{2}\right]$ $7 \mathrm{H}_{2} \mathrm{O}(2: 2 \mathrm{Zr}(\mathrm{IV})-\mathrm{Kg}$ POM) also belong to the group of $\mathrm{Zr}(\mathrm{IV})-$ substituted POMs used in the dipeptide hydrolysis. The rate constants for Gly-Gly and Gly-Ser hydrolysis were $4.44 \times 10^{-7} \mathrm{~s}^{-1}$ and $63.3 \times 10^{-7} \mathrm{~s}^{-1}$, respectively, at pH 5.4 and $60^{\circ} \mathrm{C}$. The hydrolysis of Gly-Gly by the 2:2 $\mathrm{Zr}(\mathrm{IV})-\mathrm{Kg}$ POM was more than two times faster than that for 1:1 Zr(IV)-Ld POM, but almost 3.5 times slower than that for the $1: 2 \mathrm{Zr}(\mathrm{IV})$-WD POM. The formation of cyclic products-diketopiperazines, accompanied the hydrolysis reaction for 2:2 $\mathrm{Zr}(\mathrm{IV})-\mathrm{Kg}$ POM, 1:2 Zr(IV)-WD POM, and 4:2 Zr(IV)-WD POM. Such dipeptide cyclization is a reversible process. The hydrolysis of cyclic dipeptides includes two steps: the ring-opening back into linear peptides and the cleavage of linear dipeptides into amino acids. The simultaneous cleavage of two amide bonds is very unlikely, as it would require a three-party process. As a result, the cyclic dipeptides are hydrolyzed about 20 times slower than the linear ones. The dipeptide cleavage by $2: 2 \mathrm{Zr}(\mathrm{IV})-\mathrm{Kg}$ POM is fastest in the $\mathrm{pD}$ range 5.0-6.5. At lower $\mathrm{pH}$, the protonation of amine nitrogen hinders the active complex formation. At higher $\mathrm{pH}$, the amount of the less active 1:2 $\mathrm{Zr}(\mathrm{IV})-\mathrm{Kg}$ POM increased, in which the $\mathrm{Zr}(\mathrm{IV})$ coordination sphere is saturated by lacunary Keggin units, causing the decrease in the number of available coordination sites, compared to 2:2 Zr(IV)-Kg POM, where Zr(IV) has two water molecules in the first coordination sphere [30].

Recently, Parac-Vogt and coworkers published results of dipeptide hydrolysis by a multi metal center POM, where two Wells-Dawson anions $\left[\mathrm{P}_{2} \mathrm{~W}_{16} \mathrm{O}_{59}\right]^{12-}$ were connected by a $\left[\mathrm{Zr}_{4}\left(\mu_{3}-\mathrm{O}\right)_{2}(\mathrm{OH})_{2}\left(\mathrm{H}_{2} \mathrm{O}\right)_{4}\right]^{10+}$ cluster, forming a tetrazirconium(IV)-substituted Wells-Dawson POM, $\mathrm{Na}_{14}\left[\mathrm{Zr}_{4}\left(\mathrm{P}_{2} \mathrm{~W}_{16} \mathrm{O}_{59}\right)_{2}\left(\mu_{3}-\mathrm{O}\right)_{2}(\mathrm{OH})_{2}\left(\mathrm{H}_{2} \mathrm{O}\right)_{4}\right] \cdot 57 \mathrm{H}_{2} \mathrm{O} \quad(4: 2 \quad \mathrm{Zr}(\mathrm{IV})-$ WD POM). Despite a higher number of $\mathrm{Zr}(\mathrm{IV})$ atoms capable to cleave the peptide bond per hydrolytic compound, no acceleration of Gly-Gly hydrolysis was observed compared to the 1:2 $\mathrm{Zr}(\mathrm{IV})-\mathrm{WD}-\mathrm{POM}$. The half time of this reaction was three times 
longer than those determined for previously studied mono-metal center Wells-Dawson POM at the same temperature. The $4: 2$ $\mathrm{Zr}(\mathrm{IV})-\mathrm{WD}$ POM was also a less effective hydrolytic agent than 2:2 $\mathrm{Zr}(\mathrm{IV})-\mathrm{Kg}$ POM, but was more effective than 1:1 Zr(IV)-Ld POM, having the rate constant $\mathrm{pD}$ dependence similar to those observed for 4:2 $\mathrm{Zr}$ (IV)-WD POM (maximum around $\mathrm{pD} 7.5$ ). The decrease in Lewis acidity of $\mathrm{Zr}(\mathrm{IV})$ is the suggested reason for a slower than expected cleavage of peptides by $4: 2 \mathrm{Zr}(\mathrm{IV})-\mathrm{WD}$ POM. The rate reduction is thought to be due to a higher number of $\mathrm{Zr}(\mathrm{IV})$ bridging oxygen atoms and a higher negative charge of the POM framework compared to other types of POM compounds studied [31].

$\mathrm{Ce}(\mathrm{IV})$-substituted Keggin-type POM $\left[\mathrm{Ce}\left(\alpha-\mathrm{PW}_{11} \mathrm{O}_{39}\right)_{2}\right]^{10-}(1: 2$ $\mathrm{Ce}(\mathrm{IV})-\mathrm{Kg} \mathrm{POM}$ ) cleaved dipeptides containing serine residues at C-terminus with rate constants $4.7-10.3 \times 10^{-7} \mathrm{~s}^{-1}$ at pH 7.0 and $60^{\circ} \mathrm{C}$ [32]. It is a reaction much slower than those observed for $\mathrm{Ce}(\mathrm{IV})$ salts [23]. The decrease in rate constant after incorporation of $\mathrm{Ce}(\mathrm{IV})$ into the POM structure may result from a lower number of available coordination sites, decrease in Lewis acidity, changes in the coordination environment, and a lower ligand exchange capacity. The $1: 2 \mathrm{Ce}(\mathrm{IV})-\mathrm{Kg}$ POM is the least efficient hydrolytic agent for dipeptides among all described here. Compared to $1: 2 \mathrm{Zr}(\mathrm{IV})-\mathrm{Kg}$ POM, the Gly-Ser hydrolysis was eight times slower. For Gly-Gly, the difference was even more pronounced. Almost a 16 -fold reaction rate decrease was observed after the change of hydrolytic compound from 1:2 Zr(IV)-Kg POM to 1:2 Ce(IV)-Kg POM [32].

\subsubsection{Various metal complexes}

Westheimer and Trapmann groups showed that $\mathrm{Co}(\mathrm{II}), \mathrm{Cu}(\mathrm{II})$ and $\mathrm{Ni}(\mathrm{II})$ ions are able to cleave Phe-Gly- $\mathrm{NH}_{2}$ and Gly-Leu dipeptides $[33,34]$. No mechanistic concepts were proposed for these reactions that were performed at $75^{\circ} \mathrm{C}$, a temperature sufficient for partial hydrolysis of dipeptides in the absence of metal ions. Moreover, these reactions could have a mixed character due to a possibility of oxidation of these metal ions (or rather their complexes with 2,6-lutidine used as a buffer) by air oxygen, which could result in oxidative peptide bond cleavage.

The $\mathrm{Co}(\mathrm{III})$ complex $\beta-\left[\mathrm{Co} \text { (trien) } \mathrm{OH}\left(\mathrm{H}_{2} \mathrm{O}\right)\right]^{2+}$ is one of the best studied metal ion complexes capable of fast peptide bonds hydrolysis [35-38]. The complete hydrolysis of Gly-Gly, Gly-Phe, Phe-Gly and Ala-Gly dipeptides occurred within $30 \mathrm{~min}$. at $\mathrm{pH} 7.5$ and $60-65^{\circ} \mathrm{C}$. The reaction of $\beta-\left[\mathrm{Co}(\text { trien }) \mathrm{OH}\left(\mathrm{H}_{2} \mathrm{O}\right)\right]^{2+}$ with a dipeptide at an equimolar ratio proceeded via the formation of a ternary complex, in which the N-terminal amine of the peptide replaced an equatorially coordinated water molecule in the octahedral $\mathrm{Co}(\mathrm{III})$ complex. This mode of coordination positioned the axially bound hydroxyl group to attack the peptide carbonyl. The N-terminal amino acid resulting from the hydrolysis remained to be coordinated to $\mathrm{Co}(\mathrm{III})$ after the reaction. The reaction mechanism is presented in Fig. 5.

Among other tested $\mathrm{Co}(\mathrm{III})$ compounds belonging to the same family of four nitrogen donors, $\left[\mathrm{Co}(\mathrm{X})(\mathrm{OH})(\mathrm{OH})_{2}\right]^{2+}, \mathrm{X}=\beta$-trien, $\alpha$ trien, tren, and (en $)_{2}$, the cis- $\beta-\left[\mathrm{Co}(\text { trien }) \mathrm{OH}\left(\mathrm{H}_{2} \mathrm{O}\right)\right]^{2+}$ complex was the most effective one. The half-time of Gly-Gly hydrolysis by cis- $\beta$ $\left[\mathrm{Co} \text { (trien) } \mathrm{OH}\left(\mathrm{H}_{2} \mathrm{O}\right)\right]^{2+}$ was $48-80$ times shorter than the hydrolysis of this peptide by other $\mathrm{Co}$ (III) compounds [37]. The peptide hydrolysis by cis- $\beta-\left[\mathrm{Co} \text { (trien) } \mathrm{OH}\left(\mathrm{H}_{2} \mathrm{O}\right)\right]^{2+}$ was not strictly dependent on the complex stereochemistry, as the reaction was also observed for $\left[\mathrm{Co}(\mathrm{en})_{2}(\mathrm{OH})(\mathrm{OH})_{2}\right]^{2+}[36]$ and for $\alpha-\left[\mathrm{Co}(\text { trien }) \mathrm{OH}\left(\mathrm{H}_{2} \mathrm{O}\right)\right]^{2+}[37]$, which can easily swap the configuration between the cis and trans species and form a mixture of different ternary complexes with the hydrolysis product.

Studies on hydrolysis of other dipeptides by cis- $\beta$ $\left[\mathrm{Co} \text { (trien) } \mathrm{OH}\left(\mathrm{H}_{2} \mathrm{O}\right)\right]^{2+}$ revealed that those containing Asp at the $\mathrm{N}$-terminus required a much higher $\mathrm{pH}$ to be hydrolyzed than most other dipeptides, readily hydrolyzed at $\mathrm{pH}$ about 7.4. No or little hydrolysis was also observed for Gly-Pro and Glu-Phe $[37,38]$.

The ternary complexes of $\mathrm{Co}(\mathrm{III})$ with bis- $N, N$-carboxymethylL-phenylalanine ( $\left.\mathrm{H}_{3} \mathrm{bcmpa}\right)$ or bis- $N, N$-carboxymethyl-L-glutamic acid $\left(\mathrm{H}_{3} \mathrm{bcmga}\right)$ and dipeptides were synthesized to improve the selectivity of $\mathrm{Co}(\mathrm{III})$-assisted peptide bond hydrolysis. In addition to the previously reported binding of $\mathrm{Co}$ (III) complexes to peptides via the amine nitrogen and amide oxygen, various weak interactions, such as hydrogen bonds, steric repulsion, electrostatic interactions affect the process of peptide hydrolysis. For $[\mathrm{Co}(\mathrm{bcmpa})(\mathrm{Gly}-\mathrm{Xaa})]^{-}$, the amount of the cleavage product, $[\mathrm{Co}(\mathrm{bcmpa})(\mathrm{Gly})]^{-}$decreased with the increasing C-terminal non-aromatic side chain volume. No hydrolysis was observed for Gly-Phe and Gly-D-Phe due to a hydrophobic interaction between

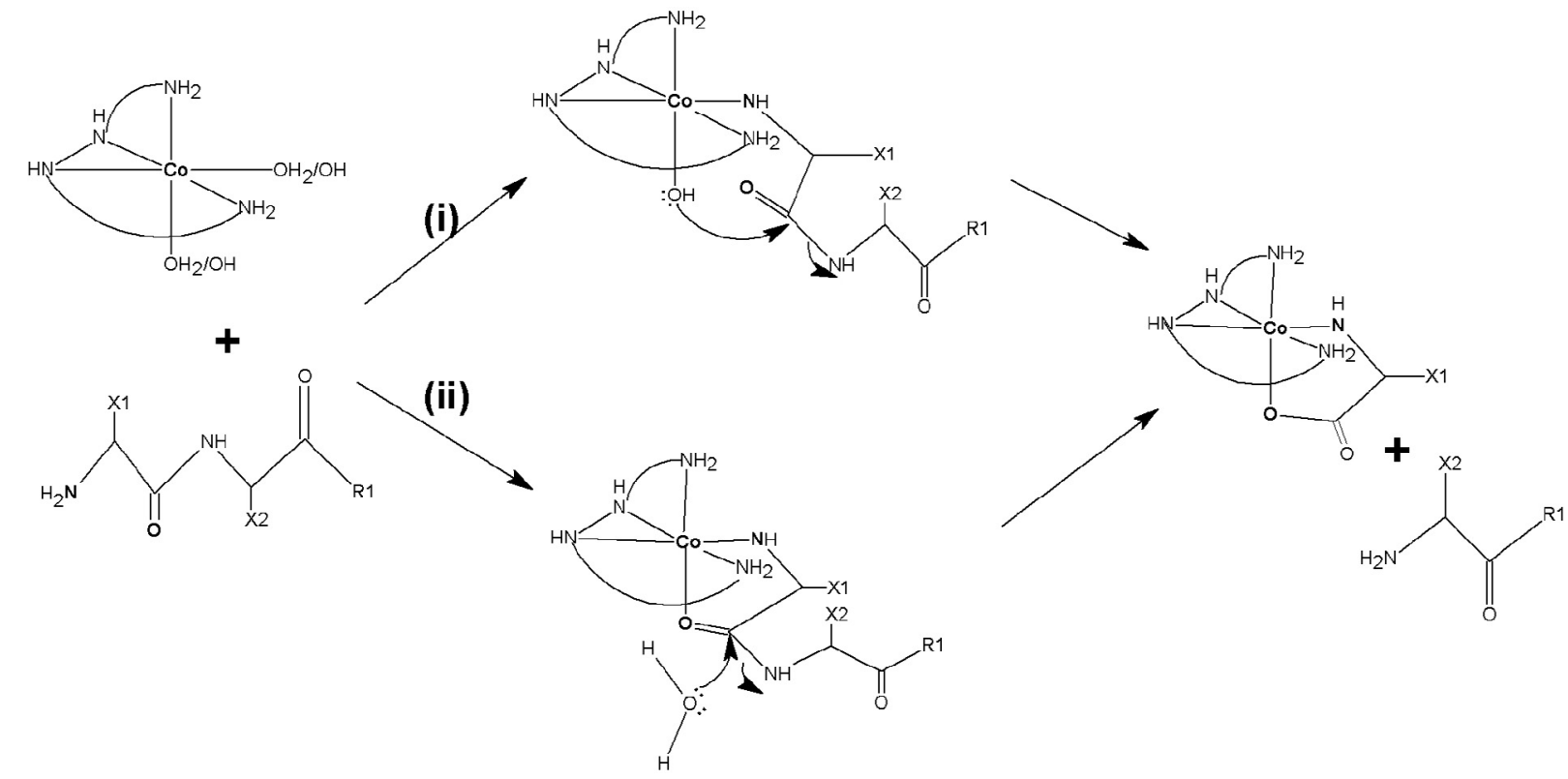

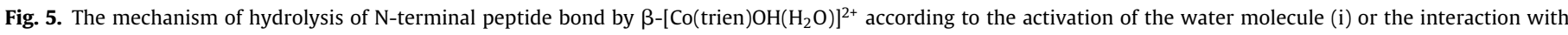
carbonyl oxygen (ii) concept of metal-assisted hydrolysis of peptide bond (2) [36]. The chirality of the complex was not indicated for a better clarity of presentation. 
the phenyl moiety and the C-terminal side chain in these dipeptides, which inhibits the hydroxide attack on the carbonyl group. The application of $\mathrm{H}_{3}$ bcmga, which has no ring in the structure, resulted in the hydrolysis of Gly-Phe and Gly-D-Phe with the yield higher than for Gly-Leu. Thus, the peptide bond cleavage in synthetic $[\mathrm{Co}(\mathrm{bcmpa})(\mathrm{Xaa}-\mathrm{Xaa})]^{-}$complexes provided an elegant example for sequence selectivity in peptide bond hydrolysis resulting from a variety of noncovalent interactions observed naturally in enzyme-catalyzed reactions [39].

\subsection{Hydrolysis of longer peptides according to Lewis acid mechanisms}

Among the metal ion based hydrolytic agents tested against dipeptides, only a few were applied successfully in the hydrolysis of longer peptides. These reactions are described in this chapter, along with those that have only been tested for such longer targets. A general rule is that the site specificity of hydrolysis depends on the anchoring of metallic agents at specific amino acid side chains.

\subsubsection{Anchoring at the N-terminus: $\mathrm{Co}(\mathrm{III})$ and $\mathrm{Ce}(\mathrm{IV})$ agents}

The $\mathrm{Co}(\mathrm{III})$ agent described in Section 2.1.5 can also hydrolyze longer peptides, having three, four or six residues, as well as the larger ones: bradykinin, glucagon, oxidized insulin chain $\mathrm{A}$, and the whole bovine insulin $[35,37]$. Since the reaction is stoichiometric rather than catalytic, the hydrolysis of longer peptides requires the molar excess of $\beta$ - $[\mathrm{Co}$ (trien $\left.) \mathrm{OH}\left(\mathrm{H}_{2} \mathrm{O}\right)\right]^{2+}$ corresponding to the number of residues in the peptide molecule, as well as longer incubation times. As described above and illustrated in Fig. 5, the reaction occurs at the $\mathrm{N}$-terminal residue. The $\mathrm{Co}$ (III) complex can be thus considered as a stoichiometric aminopeptidase.

The preference to cleave the $\mathrm{N}$-terminal over the C-terminal peptide bond was also observed for the hydrolysis of Gly-Gly-Gly and Gly-Gly-Gly-Gly by $\mathrm{Ce}\left(\mathrm{NH}_{4}\right)_{2}\left(\mathrm{NO}_{3}\right)_{6}$, as well as for the hydrolysis of Gly-Gly-Phe and Phe-Gly-Gly by $\mathrm{Ce}(\mathrm{IV})$ and $\gamma$-cyclodextrin $[23,25]$. It is a consequence of the formation of a favorable fivemembered ring including the $\mathrm{N}$-terminal amino group and the corresponding carbonyl group. The cleavage of the next peptide bond according to the Lewis acid mechanism in longer peptides would be associated with the formation of an unfavorable sevenmembered ring.

\subsubsection{Anchoring at the Cys side chain: molybdocene.}

Erxleben showed that molybdocene dichloride, $\mathrm{Cp}_{2} \mathrm{MoCl}_{2}$, was able to cleave the Cys-Gly peptide bond in GSH and Gly-Cys-Gly [40]. The incubation of $\mathrm{Cp}_{2} \mathrm{MoCl}_{2}$ with GSH resulted in the formation of a number of ternary complexes. Their distribution depended on the $\mathrm{pH}$, temperature, and the peptide: $\mathrm{Cp}_{2} \mathrm{MoCl}_{2}$ ratio. In hydrolytically active complexes, Mo(IV) was coordinated only by the glutathione thiolate. Such arrangement allows for the nucleophilic attack of the hydroxide ion provided by $\mathrm{Mo}(\mathrm{IV})$ on the Cys-Gly peptide bond carbonyl group. This reaction is regioselective. Only the Cys-Gly peptide bond was cleaved, as a result of the formation of a more favorable six-membered chelate ring. The $\gamma$-Glu-Cys bond cleavage would require the formation of a seven-membered ring. The yield of this reaction at $\mathrm{pH} 7.4$ and room temperature was low, because the active complex amounted only to $10 \%$ of total Mo(IV) complexes. A temperature increase to $60^{\circ} \mathrm{C}$ caused the conversion of other complexes to the hydrolytically active one, increasing the conversion degree to $80 \%$. The mechanism of this reaction is illustrated in Fig. 6.

The treatment of the Gly-Cys-Gly peptide by $\mathrm{Cp}_{2} \mathrm{MoCl}_{2}$ also leads to the cleavage of the C-terminal Cys-Gly peptide bond, but according to a different mechanism, based on the intermolecular aminolysis. The products of this reaction are the 2,5-diketopiperizine derivative cyclo-(Gly-Cys) and glycine. This reaction proceeded specifically in the presence of $\mathrm{Cp}_{2} \mathrm{MoCl}_{2}$. No condensation was observed in the control experiments without the metal complex. The cyclic product was formed at the same rate as the released glycine. $\mathrm{Cp}_{2} \mathrm{Mo}^{2+}$ was proposed to assist the cistrans isomerization of the amide bond, which is required for the cyclization process. This particular reaction was mediated specifically by the complex having Mo(IV) coordinated by the thiolate and the amide nitrogen, and required heating. The 2:1 peptide-Mo(IV) complex, also present in the reaction solution, was hydrolytically inactive, even at the elevated temperature. The reaction mechanism presented in Fig. 7 was confirmed by experiments on a range of model peptides [40]. No complex formation and no hydrolysis was observed for molecules without a thiolate docking site for $\mathrm{Cp}_{2} \mathrm{Mo}^{2+}$, glycinamide and the activated amide, glycine- $p$ nitroanilide (Gly-pNA). Ac-Cys, Cys-Gly, and Gly-Cys formed 2:1 complexes with $\mathrm{Cp}_{2} \mathrm{Mo}^{2+}$, containing $\mathrm{S}, \mathrm{O}-$ and $\mathrm{S}, \mathrm{N}$-chelates, but none of them was hydrolytically active.

\subsubsection{Anchoring at Met, Cys and His side chains: Pd(II) and Pt(II)}

The studies of peptide bond hydrolysis by $\mathrm{Pd}(\mathrm{II})$ and $\mathrm{Pt}(\mathrm{II})$ ions and complexes by Kostić and coworkers were presented in a coherent series of papers describing the substrates spanning from dipeptides to proteins. Because the bulk of their work regarded oligopeptides, we chose to describe their introductory dipeptide experiments below, along with the rest of their peptide studies, instead of Section 2.1.

In contrast to the previously described reactions, the $\mathrm{Pd}(\mathrm{II}) / \mathrm{Pt}(\mathrm{II})$-assisted hydrolysis of peptide bonds requires the presence of the coordinating side chain Cys, Met, or His in the cleaved peptide or protein sequence. The cleavage mechanism is similar to those described previously and summarized in Fig. 2, combining the internal water molecule delivery (i) or the external attack of a solvent-derived water molecule (ii), but the specific coordination properties of these metal ions resulted in novel sequence specificities of hydrolysis [41-43].

Studies on short peptides (dipeptides and tripeptides including glutathione) revealed that $\mathrm{Pt}(\mathrm{II})$ and $\mathrm{Pd}(\mathrm{II})$ complexes preferentially cleaved peptide bonds involving the carboxylic group of the anchoring side chain. The release of glycine was observed after the reaction of Ac-Met-Gly, GSH and S-methylglutathione (GSMe) with $\left[\mathrm{PtCl}_{4}\right]^{2-}$. No hydrolysis was observed for Met-Gly, due to the $\mathrm{Pd}(\mathrm{II})$ coordination via the amine nitrogen and the side chain sulfur. A very slow release of acetic acid was noted for $\mathrm{N}$-acetylcysteine and S-methyl-N-acetylcysteine, but not for $\mathrm{N}$-acetylmethionine, where there were no amide bonds at the carboxyl side of the anchoring residue. However, the acetic acid release was around 140 times slower than the peptide bond hydrolysis in Ac-Met-Gly, GSH and GSMe. For GSMe, the hydrolysis promoted by $\mathrm{Pt}(\mathrm{II})$ compounds was 10 times faster than for $\mathrm{Pd}(\mathrm{II})$ compounds, with rate constants $3.67 \times 10^{-5} \mathrm{~s}^{-1}$ and $3.67 \times 10^{-6} \mathrm{~s}^{-1}$ at pH $1.2-1.3$ and $40^{\circ} \mathrm{C}[41,42]$.

$\mathrm{Pd}(\mathrm{II})$ ions are able also to bind at the His imidazole [43-45]. The hydrolysis of di- and tripeptides occurs at the carboxyl side of an anchoring His residue, according to the same pattern as for peptides containing anchoring Cys and Met when $\left[\mathrm{PdCl}_{4}\right]^{2-}$ was used [43]. For the hydrolysis caused by $\left[\mathrm{Pd}\left(\mathrm{H}_{2} \mathrm{O}\right)_{4}\right]^{2+}$ both peptide bonds around the anchoring side chain were cleaved at comparable rates, as shown for Ac-His-Gly [46]. The rate constant for hydrolysis of Ac-His-Xaa dipeptides by $\left[\mathrm{PdCl}_{4}\right]^{2}$ decreased with the side chain volume increase from $2.8 \times 10^{-5} \mathrm{~s}^{-1}$ for Ac-His-Gly to $5 \times 10^{-5} \mathrm{~s}^{-1}$ for Ac-His-Tyr at pD 1.46 and $60^{\circ} \mathrm{C}$. In contrast to the hydrolysis of peptides containing Cys and Met in aqueous solution, the $\mathrm{Pd}(\mathrm{II})$-assisted hydrolysis of Ac-His-Xaa was catalytic (turnover rate $\geq 4$ ), due to the lability of $\mathrm{Pd}(\mathrm{II})$ complexes. The authors concluded that for the catalytic reaction to occur, the products should be weaker Pd(II) chelators than the substrate. Therefore, side chains in the vicinity of the anchoring residue should be non-coordinating. 
<smiles>NC(CCC(=O)NC(CS)C(=O)NCC(=O)[O-])C(=O)[O-]</smiles><smiles>C[C+](C)CC(=O)ON(O)O</smiles>

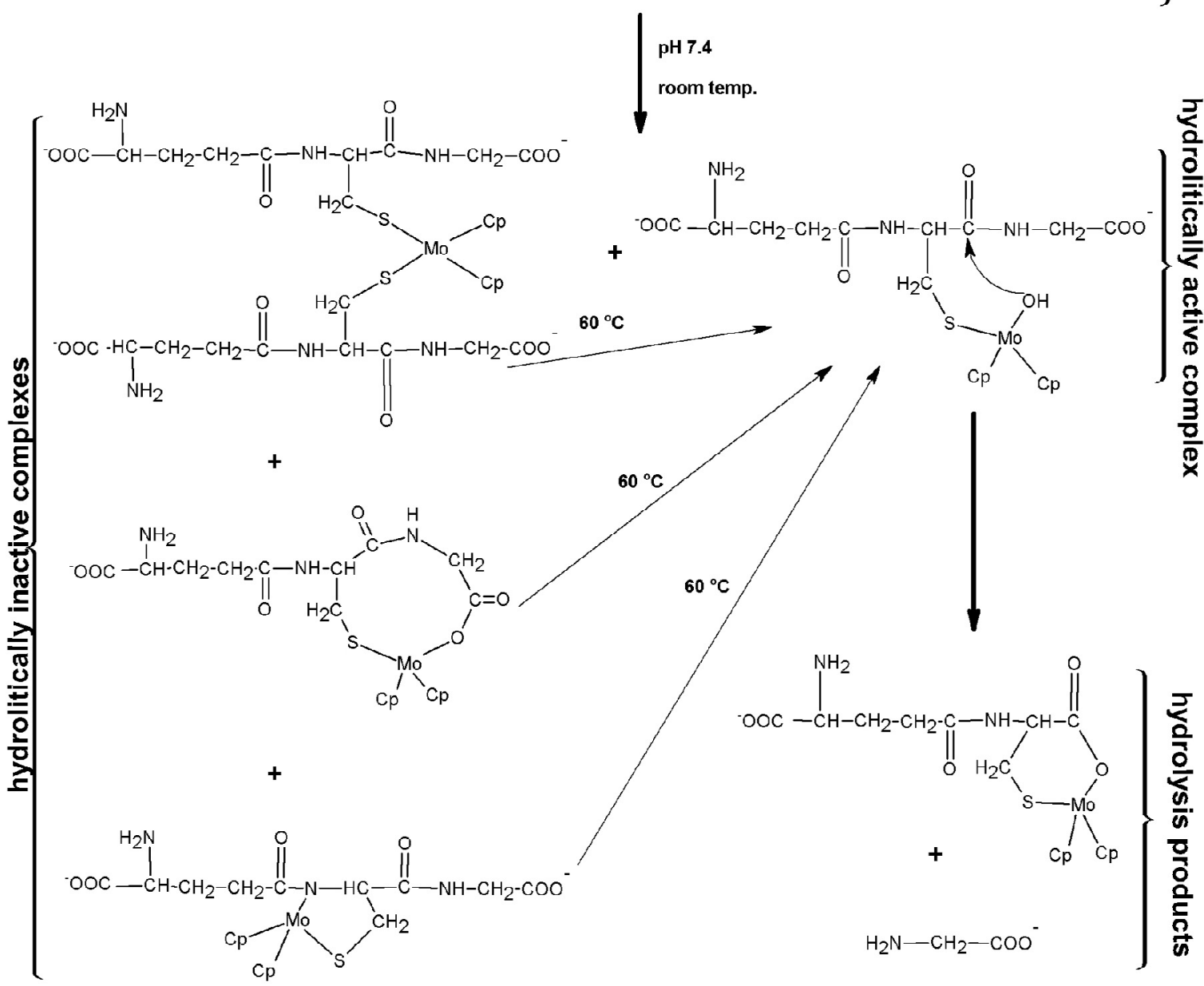

Fig. 6. The mechanism of hydrolysis of $\gamma$-Glu-Cys-Gly (glutathione) by $\mathrm{Cp}_{2} \mathrm{MoCl}_{2}$, where $\mathrm{Cp}$ is $\eta 5$-cyclopentadienyl [40].

Otherwise, the cleavage was stoichiometric, as for the His-Ala peptide bond in Ac-Cys-His-Ala [43].

Naturally occurring peptides, including pentagastrin, angiotensin II, insulin chains A and B, methionine enkephalin, as well as the protein fragments: a 19-amino acid fragment of the monomeric protein myohemerythrin and the 11-14 sequence of angiotensinogen were employed to determine the rules for sequence specificity of $\mathrm{Pd}(\mathrm{II}) / \mathrm{Pt}(\mathrm{II})$-assisted hydrolysis in amino acid sequences longer than tripeptides and to explain the differences between the reactivities in these two substrate types [47-49]. No hydrolysis was observed for the oxidized insulin chain A, which contains no His, Met, or reduced Cys residues. An analogous situation was noted for human pentagastrin and the fragment of human angiotensinogen, where Met and His are present at the third position in the sequence, respectively. The presence of free terminal amino group in these peptides resulted in the formation of hydrolytically inactive $\mathrm{Pd}(\mathrm{II})$ complexes. The presence of free N-terminus also inhibited the hydrolysis by $\mathrm{Pd}(\mathrm{II})$ in peptides with Met and His as the first, second or third residue of the sequence. This is due to the formation of bis(bidentate), tridentate or tetradentate complexes involving the anchoring side chain and the upstream main chain nitrogens. If the anchoring side chain was in the position four or further down the peptide chain, then $\operatorname{Pd}(\mathrm{II})$ ions cleaved the second peptide bond upstream or the first downstream from the anchoring residue [47-49]. Pt(II) hydrolyzes the first peptide bond downstream the Met residue [50]. This mechanism is presented in Fig. 8 for the example of $\mathrm{Pd}(\mathrm{II})$-assisted hydrolysis of peptide containing a His residue.

At pH 2.3 the hydrolytically active bidentate complex 2 and the hydrolytically inactive complex 3 were present in the solution. Complex 2 caused the cleavage of the second peptide bond downstream of His, because it was appropriately oriented toward this bond and contained coordinated water molecules, suitable to be exchanged with the carbonyl oxygen in the coordination sphere of Pd(II) (mechanism (ii) in Fig. 2) or to deliver a water molecule according to the internal mechanism (i). The Pd(II) coordination via the nitrogen atoms of the second and the third peptide bond downstream of His (complexes 3 and 4, respectively) made the $\mathrm{Pd}(\mathrm{II})$ complex inactive. Complex 1 is also active and causes the cleavage of the first peptide bond downstream of His, but it can exist only at very low $\mathrm{pH}$, due to the significant decrease of amide nitrogen $\mathrm{p} K_{\mathrm{a}}$ by $\mathrm{Pd}(\mathrm{II})$ (to ca. 2.0). At $\mathrm{pH} 0.5$, where both active 


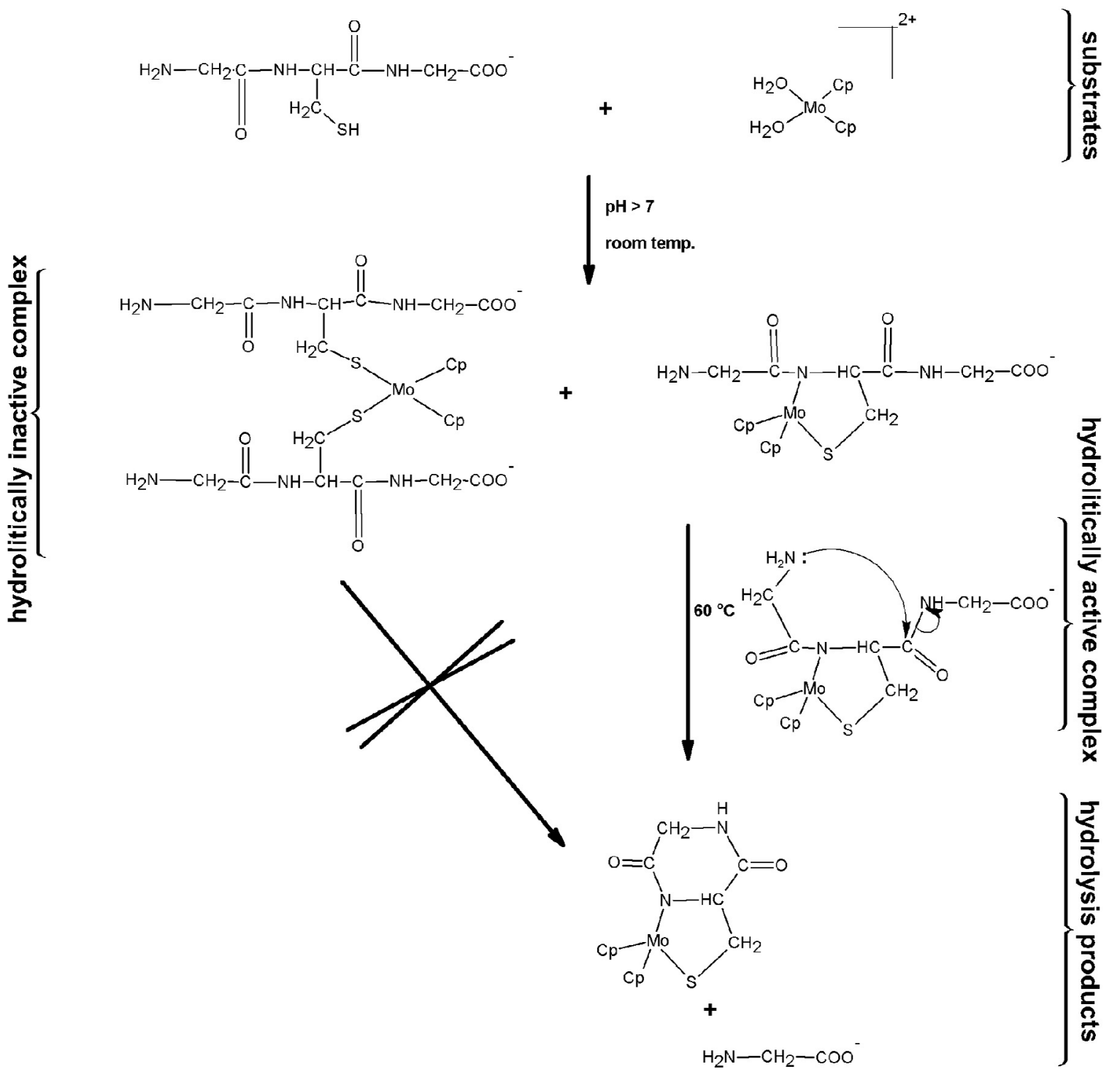

Fig. 7. The mechanism of hydrolysis of Gly-Cys-Gly by $\mathrm{Cp}_{2} \mathrm{MoCl}_{2}$, where $\mathrm{Cp}$ is $\eta^{5}$-cyclopentadienyl [40].

complexes were present, the hydrolysis of the first and the second peptide bonds downstream of His was detected [49]. The Pd(II)assisted hydrolysis is limited to the $\mathrm{pH}$ range about $1.0-4.0$ not only due to the coordination of metal ions by amine or amide nitrogens, but also due to the formation of insoluble, hydroxo-bridged Pd(II) complexes at a higher $\mathrm{pH}$. The $\mathrm{Pd}(\mathrm{II})$ assisted reactions were also accompanied by acid-promoted background cleavage of peptide bonds at $\mathrm{pH}$ below 1.5 [49]. The extension of $\mathrm{pH}$ range for $\mathrm{Pd}(\mathrm{II})-$ assisted hydrolysis was achieved for the cleavage of the Xaa-Pro peptide bond in Xaa-Pro-His and Xaa-Pro-Met sequences. Pro is the only amino acid residue forming a tertiary peptide bond, which lacks the hydrogen atom and thus makes its peptide bond, second downstream of His/Met, unavailable for Pd(II) binding. The Xaa-Pro peptide bond was more susceptible to hydrolysis than Xaa-Gly in the Xaa-Pro/Gly-Met/His sequence. The rate constants of hydrolysis were $9.8 \times 10^{-4} \mathrm{~s}^{-1}$ and $4.7 \times 10^{-4} \mathrm{~s}^{-1}$ respectively at $\mathrm{pH} 2.0$ and $60^{\circ} \mathrm{C}$. At $\mathrm{pH} 7.0$ the rate of $\mathrm{Pd}(\mathrm{II})$-assisted hydrolysis of the Xaa-Pro peptide bond was similar to that observed for the Xaa-Gly peptide bond at $\mathrm{pH} 2.0$ in the Xaa-Pro/Gly-Met/His sequence [51]. No preferences for Met or His were seen for the hydrolysis of a peptide containing both anchoring side chains, and the similar rate constants were established for His- or Met-containing peptides
[49]. According to the DFT calculation the most preferred mechanism of this reaction involved the creation of the active bidentate complex of $\left[\mathrm{Pd}\left(\mathrm{H}_{2} \mathrm{O}\right)_{4}\right]^{2+}$ and peptide in the trans configuration and the internal rather than external attack. The substitution of $\mathrm{Pd}(\mathrm{II})$ with $\mathrm{Pt}(\mathrm{II})$ caused a small reduction in the energy barrier by $0.53 \mathrm{kcal} / \mathrm{mol}$ [52].

The residue selective hydrolysis of peptide bonds preceding Pro was observed for peptides without anchoring groups (Met, Cys, or His) in the presence of $\left[\mathrm{Pd}\left(\mathrm{H}_{2} \mathrm{O}\right)_{4}\right]^{2+}$. The rate constant of the cleavage of the Ala-Pro bond for Ac-Ala-Ala-Pro-Ala-nephtylamide was $6.4 \times 10^{-5} \mathrm{~s}^{-1}$ at $\mathrm{pH} 7.0$ and $60^{\circ} \mathrm{C}$. For peptides containing more Pro residues, the hydrolysis of all peptide bonds preceding Pro was observed. Application of a conjugate of $\left[\mathrm{Pd}\left(\mathrm{H}_{2} \mathrm{O}\right)_{4}\right]^{2+}$ and $\beta$-cyclodextrin resulted in a sequence selective hydrolysis. $\beta$ cyclodextrin recognized aromatic residues (Phe, Tyr, and Trp) and only peptide bonds preceding Pro, which were in the proximity to the aromatic residues were cleaved [53]. The theoretical calculation according to the hybrid quantum mechanics/molecular mechanics approach revealed that the inclusion of the cyclodextrin ring at two $\mathrm{CH}_{2}$ groups downstream of the metal center could cause a three-hundred-thousand-fold acceleration of the reaction toward the Ser-Pro-Phe sequence. The Co(II) ion is theoretically more 

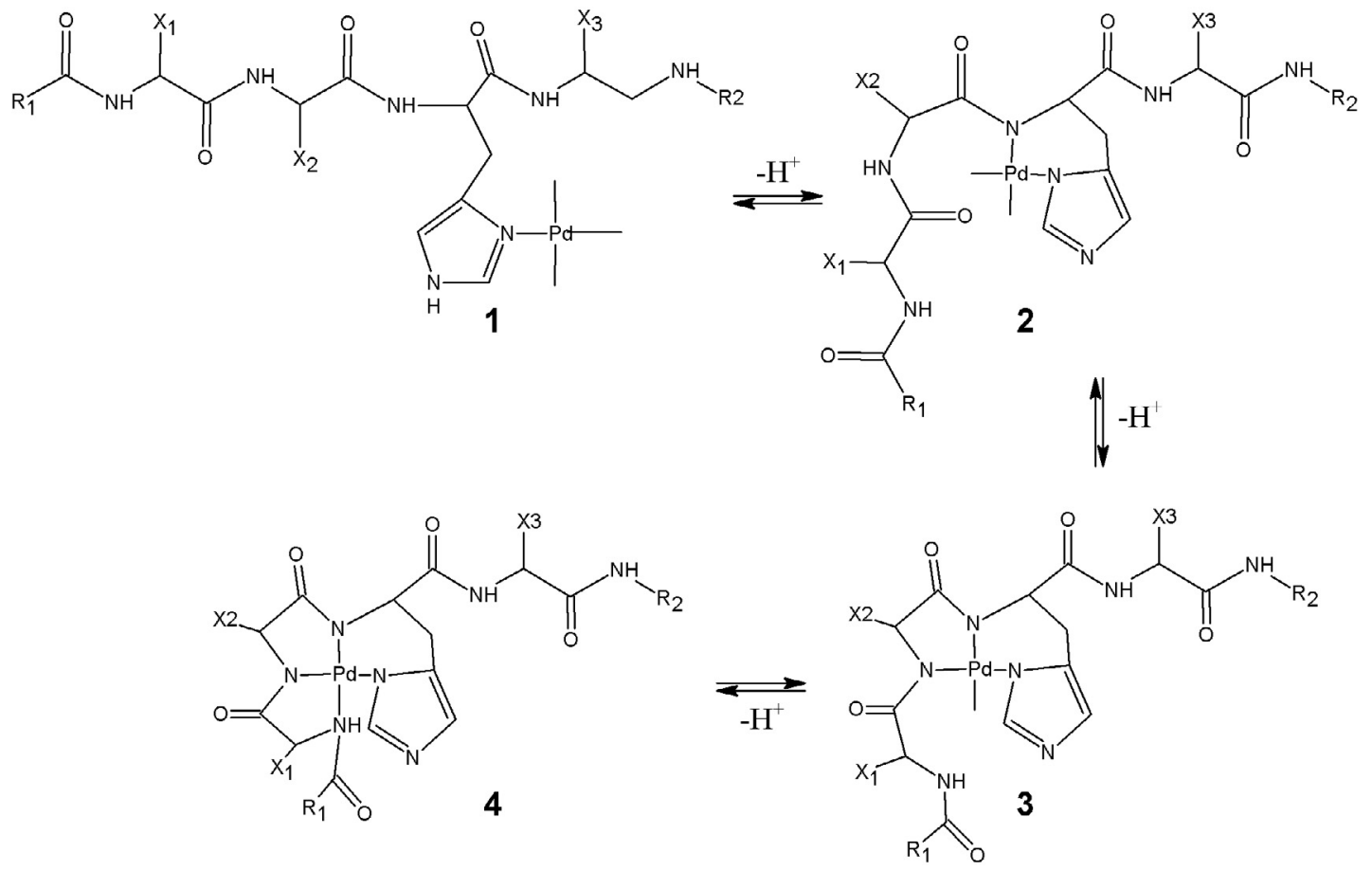

Fig. 8. The formation of hydrolytically active and inactive complexes for peptides containing His as an anchoring site for Pd(II) ions [47].

suitable than Pd(II) for this conjugate. The metal replacement could increase the rate constant of hydrolysis by further 37,000 times [54].

The impact of the precursor $\mathrm{Pd}(\mathrm{II})$ species on the hydrolytic activity was determined using the Ac-Ala-Lys-TyrGly-Gly-Met-Ala-Ala-Arg-Ala peptide. The hydrolysis by $\left[\mathrm{Pd}\left(\mathrm{H}_{2} \mathrm{O}\right)_{4}\right]^{2+}$ or $\left[\mathrm{Pd}\left(\mathrm{NH}_{3}\right)_{4}\right]^{2+}$ was almost two times faster than the hydrolysis by $\left[\mathrm{PdCl}_{4}\right]^{2-}$ or cis- $\left[\mathrm{Pd}(\mathrm{en})\left(\mathrm{H}_{2} \mathrm{O}\right)_{2}\right]^{2+}$. This finding can be easily explained by the fact that $\mathrm{H}_{2} \mathrm{O}$ and $\mathrm{NH}_{3}$ ligands are bound more weakly to the $\mathrm{Pd}(\mathrm{II})$ ion and could be exchanged quickly for peptide donor atoms. Chloride ions and ethylenediamine form more stable $\mathrm{Pd}(\mathrm{II})$ complexes. In addition, chlorides decrease the $\operatorname{Pd}(\mathrm{II})$ Lewis acidity [49]. For 2-picolylamine, a $\mathrm{Pd}(\mathrm{II})$ chelator more bulky than ethylenediamine, a significant deceleration of hydrolysis was observed for Ac-Met-Gly-His-Gly- $\mathrm{NH}_{2}$ and Ac-Met-Gly-Gly peptides. The application of 2,2-dipyridylamine, the most bulky among ligands studied for Pd(II), resulted in the inhibition of the peptide cleavage [55,56].

Differences in the cleavage pattern between $\mathrm{Pt}(\mathrm{II})$ - and $\mathrm{Pd}(\mathrm{II})$-assisted hydrolysis are caused by the contrasting ligand exchange properties of these metals, as demonstrated for the cis$\left[\mathrm{Pd} / \mathrm{Pt}(\mathrm{en})\left(\mathrm{H}_{2} \mathrm{O}\right)_{2}\right]^{2+}$ couple. $\mathrm{Pt}(\mathrm{II})$ is much more inert than $\mathrm{Pd}(\mathrm{II})$ with respect to the ligand substitution. Only the $\mathrm{Pt}(\mathrm{II})$ analog of complex 1 from Fig. 8, where the $\mathrm{Pt}(\mathrm{II})$ ion is coordinated via Met sulfur (Pt(II) does not eagerly bind to the His residue) is the hydrolytically active complex. Due to the $\mathrm{Pt}(\mathrm{II})$ binding at the amide nitrogen, the resulting complex 2 is inactive, as it does not contain water molecules required for the Lewis acid mechanism of Pt(II)assisted peptide bond hydrolysis. The remaining $\mathrm{Pt}(\mathrm{II})$ coordination sites are occupied by ethylenediamine, which cannot be easily replaced by water molecules, in contrast to the reaction observed for Pd(II) [50,52].

In addition to mononuclear Pt(II) complexes, dinuclear ones containing different bridging diazine ligands, such as pyrazine and pyridazine, were tested for their hydrolytic activities, at $2.0<\mathrm{pH}>2.5[57-60]$. The complex $\left\{\left[\mathrm{Pt}(\mathrm{en})\left(\mathrm{H}_{2} \mathrm{O}\right)\right]_{2}(\mu-\mathrm{pz})\right\}^{4+}$ with two $\mathrm{Pt}(\mathrm{II})$ ions bridged by pyrazine was more efficient than the corresponding mononuclear complex in the hydrolysis of Ac-Met-Gly. The better catalytic activity of the dinuclear vs. the mononuclear Pt(II) complex was attributed to a possible cooperation between two pyrazine-bridged Pt(II) ions. One of the $\mathrm{Pt}(\mathrm{II})$ ion in such complex could polarize the carbonyl oxygen atom and the other could deliver a water molecule [60]. Between the two tested bridging ligands, the pyridazine complex was less active. It is probably the result of an increased steric effect emerging from the ortho-position of the two nitrogen atoms in the pyridazine ring. As a consequence, the pyridazine $\mathrm{Pt}(\mathrm{II})$ dimer promotes the cleavage of the peptide bond involving the Met but not the His residue. In contrast, the pyrazine Pt(II) dimer cleaves peptide bonds next to Met and His residues [58].

Diamminedichloroplatinum(II), the active component of cisplatin, a well-known anticancer drug hydrolyzed a range of oligopeptides containing Met or His residues at weakly acidic $\mathrm{pH}$. The complex reacted rather slowly (days), as the reaction kinetics expended additionally on the rate of replacement of chloride ligands with water molecules that reacted with the peptide substrate according to the Lewis acid mechanisms. The sequence specificity observed for cisplatin was analogous to that described above for other Pt(II) and Pd(II) complexes [61,62].

In the protein sequences, cysteine residues are usually involved in the disulfide bridges, which are not prone to coordinate $\mathrm{Pd}(\mathrm{II})$ or Pt(II) ions. The reduced cysteine was a useful anchoring side chain for $\mathrm{Pd}(\mathrm{II}) / \mathrm{Pt}(\mathrm{II})$-assisted hydrolysis, but systematic studies of its reactivity were not undertaken $[41,42]$.

\subsection{Proteins}

Peptides, so widely used in this research area, are not the main targets of metal-assisted hydrolysis. They merely serve as models for protein reactions, as their much less complicated structure is more suitable for the detailed description of interactions with metals. Many metal compounds, which were successfully applied to cleave peptides were also employed in protein hydrolysis. Some of them required modification for applications with proteins. 
Several compounds were also tested in protein reactions without previous or follow-up studies on model peptides. Bovine serum albumin (BSA) is probably the most frequent target protein for testing hydrolytic compounds, due to its perfect solubility, and very good commercial availability. Other popular proteins include human serum albumin (HSA), hen-egg-white lysozyme (HEWL), and horse heart myoglobin (Mb). The comparison of sites of cleavage caused by various hydrolytic agents except $\mathrm{Pd}(\mathrm{II})$ and $\mathrm{Pt}(\mathrm{II})$ compounds described below for these four proteins is presented in the Supporting Information Figs. S1-S4, which present amino acid sequences with the cleavage sites marked. These figures are accompanied by protein structure animations (Figs. S5-S8). We decided not to include $\mathrm{Pd}(\mathrm{II})$ and $\mathrm{Pt}(\mathrm{II})$ cleavage sites for the clarity of the presentation due to a usually high number of hydrolysis sites in respective proteins, caused by these metal ions.

\subsection{1. $\mathrm{Cu}(\mathrm{II}), \mathrm{Co}(\mathrm{III})$ and $\mathrm{Zn}(\mathrm{II})$ complexes}

BSA hydrolysis by $\mathrm{Cu}(\mathrm{II})$ 1,4,7-triazacyclononane dichloride $\left.\left(\mathrm{Cu}[9] \mathrm{aneN}_{3}\right) \mathrm{Cl}_{2}\right)$ was one of the first examples for protein hydrolytic cleavage by a metal compound. Two fragments, with molecular masses approximately 27 and $40 \mathrm{kDa}$ were observed after an incubation of BSA (66 kDa) with $\left.\mathrm{Cu}[9] \mathrm{aneN}_{3}\right) \mathrm{Cl}_{2}$ in a HEPES buffer, as a result of the cleavage of Cys243-Cys244 and Gln219-Lys220 peptide bonds (confirmed by Edman degradation). The hydrolysis of two other bonds, Ser270-Ser271 and Glu250-Cys251 is less certain. The selection of cleavage sites was associated with a specific local conformation of the protein, rather than the specific amino acid residues. The reaction was slow. After 7 days at $\mathrm{pH} 7.8$ and $50^{\circ} \mathrm{C}$ only about $12.5 \%$ of BSA $(0.21 \mathrm{mM})$ was cleaved by $\left.1 \mathrm{mM} \mathrm{Cu}[9] \mathrm{aneN}_{3}\right) \mathrm{Cl}_{2}$. The hydrolytic nature of the reaction was supported by performing the experiments under anerobic conditions and confirmed by a successful identification of BSA fragments by Edman degradation. The reaction was declared to be catalytic on the basis of experiments with Gly-Gly mentioned in the paper, but no mechanistic information was provided to substantiate this declaration [63].

BSA was also susceptible to hydrolysis in the presence of [ $\mathrm{Cu}\left(\mathrm{HL}^{1}\right) \mathrm{Cl}_{2}$ ], where $\mathrm{HL}^{1}$ is 2-[(bis(pyridylmethyl)amino)methyl]4-methyl-6-formylphenol. At pH 7.2 and $50^{\circ} \mathrm{C}$ or $70^{\circ} \mathrm{C}$, the reaction half times were 30 and $0.2 \mathrm{~min}$, respectively. It makes $\left[\mathrm{Cu}\left(\mathrm{HL}^{1}\right) \mathrm{Cl}_{2}\right]$ a much more effective reagent than $\left.\mathrm{Cu}[9] \mathrm{aneN}_{3}\right) \mathrm{Cl}_{2}$, but also a clearly less specific one. The cleavage sites in this case were proposed to be present in the following regions: Phe205-Glu207, Val292-Asp295, Lys362-His366, and Cys436-Glu441, on the basis of gel electrophoresis and mass spectrometry, but the bonds actually hydrolyzed were not indicated. The $\mathrm{pH}$ optimal for hydrolysis was 7.2, where the most active species (the deprotonated form of $\left[\mathrm{Cu}\left(\mathrm{HL}^{1}\right) \mathrm{Cl}_{2}\right]$ ) was the only complex species observed in the solution. The $\mathrm{Cu}(\mathrm{II})$ ion was bound via two pyridine and one amino nitrogens, a phenol oxygen, and two chlorides. The distance between the phenol oxygen and $\mathrm{Cu}$ (II), $2.82 \AA$ is one of the longest one observed for such complexes. It is a consequence of the protonation of the phenol group and the presence of an intramolecular hydrogen bond. After the phenol group deprotonation, the distance between $\mathrm{Cu}(\mathrm{II})$ and the phenol oxygen was shortened to $2.13 \AA$. This unique binding mode and labile coordination sites probably caused such fast hydrolysis of proteins by this complex. The oxidative cleavage was excluded by obtaining similar results with and without hydroxyl radical scavengers and under anerobic conditions. $\mathrm{Cu}\left(\mathrm{HL}^{1}\right) \mathrm{Cl}_{2}$ also caused degradation of Taq DNA polymerase under conditions typical for polymerase chain reaction assays (PCR). The application of $30 \mu \mathrm{M}\left[\mathrm{Cu}\left(\mathrm{HL}^{1}\right) \mathrm{Cl}_{2}\right]$ resulted in the hydrolysis of $50 \%$ of Taq DNA polymerase during the experiment. The PCR reaction inhibition was too strong to result from the amount of cleaved Taq DNA polymerase, perhaps due to an interaction of the studied complex with the catalytic site of the enzyme and with DNA.
$\left[\mathrm{Cu}\left(\mathrm{HL}^{1}\right) \mathrm{Cl}_{2}\right]$ did not, however, cleave DNA under the conditions used in the experiment [64].

Yet another $\mathrm{Cu}(\mathrm{II})$ complex able to hydrolyze $\mathrm{BSA}$ is $[\mathrm{Cu}(\mathrm{tdp})(\mathrm{tmp})] \mathrm{ClO}_{4}$, where $\mathrm{H}(\mathrm{tdp})$ is $2-[(2-(2-$ hydroxyethylamino)ethylimino)methyl]phenol and tmp is $3,4,7,8$ tetramethyl-1,10-phenanthroline. The mixed ligand character of these complexes was necessary for its hydrolytic activity. The tetradentate phenolate ligand was responsible for the formation of stable, square-planar $\mathrm{Cu}(\mathrm{II})$ complexes. The diimine recognized and interacted with the protein (tmp binds to hydrophobic protein domains). Hydrolysis did not occur for the $\mathrm{Cu}(\mathrm{II})$ complexes without tmp ([Cu(tdp) $] \mathrm{ClO}_{4} \cdot 0.5 \mathrm{H}_{2} \mathrm{O}$ ), and after replacing tmp with other diimines, such as 2,2'-bipyridine, 1,10-phenanthroline, and dipyrido[3,2-d:2',3'-f]quinoxaline. No cleavage was observed for $\mathrm{Cu}\left(\mathrm{ClO}_{4}\right)_{2} \cdot 6 \mathrm{H}_{2} \mathrm{O}$ and for $\mathrm{H}(\mathrm{tdp})$ and tmp ligands without $\mathrm{Cu}(\mathrm{II})$. Incubation of $\mathrm{BSA}$ and $\mathrm{HEWL}$ with $[\mathrm{Cu}(\mathrm{tdp})(\mathrm{tmp})] \mathrm{ClO}_{4}$ resulted in the appearance of new fragments with approximate molecular masses $5 \mathrm{kDa}$ and $4 \mathrm{kDa}$, respectively. By comparing their results with the previous literature [65,66], Rajendiran and co-workers suggested that cleavage of BSA and lysozyme by $[\mathrm{Cu}(\mathrm{tdp})(\mathrm{tmp})] \mathrm{ClO}_{4}$ occurred at Ala150-Pro151 and after Ser190 peptide bond for BSA and at Trp108-Val109, as well as Glu35-Asp52 for HEWL. The hydrolysis of BSA and HEWL by $[\mathrm{Cu}(\mathrm{tdp})(\mathrm{tmp})] \mathrm{ClO}_{4}$ was extremely fast. The half time at physiological $\mathrm{pH}$ and temperature was $1.7 \mathrm{~min}$ for BSA and $2.3 \mathrm{~min}$ for HEWL. The hydrolytic character of this reaction was proved by performing the experiments in the presence of a radical scavenger and under anerobic atmosphere [67].

HEWL was also cleaved by $\mathrm{Co}(\mathrm{III})$ complexes, pentaammineaquacobalt(III) (CoPA) and tetraamminediaquacobalt(III) (CoTA) [68]. In this case, $\mathrm{Co}$ (III) compounds acted as exopeptidases, rather than the endopeptidase $\beta-\left[\mathrm{Co} \text { (trien) } \mathrm{OH}\left(\mathrm{H}_{2} \mathrm{O}\right)\right]^{2+}$ described in Sections 2.1.5 and 2.2. In the presence of other $\mathrm{Co}(\mathrm{III})$ compounds, hydrolysis did not occur (for cis or trans isomers of bisethylenediaminediaquacobalt(III) bromide, hexaamminecobalt(III) chloride) or was very slow (for chloropentamminecobalt(III), chlorotetraamminecobalt(III) or chlorotetraamminecarbonatocobalt(III)). After the incubation of HEWL (approximately $14 \mathrm{kDa}$ ) with CoTA and $\mathrm{CoPA}$ at $37^{\circ} \mathrm{C}$ and neutral $\mathrm{pH}$, two new fragments (approximately 2 and $12 \mathrm{kDa}$ ) were noticed. Mass spectrometry and Edman degradation methods indicated that they resulted from the Ala110-Trp111 peptide bond cleavage. However, this reaction did not affect the activity of this enzyme [68].

$\mathrm{Co}$ (III) and $\mathrm{Cu}(\mathrm{II})$ complexes with a combinatorial library of cyclen (Cyc) derivatives with peptide nucleic acids (PNA) were synthesized to selectively hydrolyze $\mathrm{Mb}$. The general formula of the studied compounds was $\operatorname{CycAc}(\mathrm{Q})_{n} \mathrm{LysNH}_{2}$, where $\mathrm{Q}$ is a PNA monomer: $A^{*}, T^{*}, G$, or $C$. $\left(A^{*}\right.$ and $T^{*}$ are modified nucleobases, which recognize $T$ and $A$ respectively, but do not recognize each other and can be used in the library method of PNA preparation). The best one (Cyc1) contains 9-mers of $A^{*}$. Its structure is shown in Fig. 9.

The Co(III) complex of Cyc1 showed a higher activity than the $\mathrm{Cu}(\mathrm{II})$ complex. The reaction half-time for $\mathrm{Co}(\mathrm{III})$ : Cyc1 was $30 \mathrm{~h}$ at $\mathrm{pH} 7.5$ and $37^{\circ} \mathrm{C}$. The cleavage at two different positions was noted for this complex, Leu89-Ala90 and Leu-72-Gly73. Fe(III), Hf(IV), $\mathrm{Pt}(\mathrm{IV}), \mathrm{Zr}(\mathrm{IV}), \mathrm{Pd}(\mathrm{II})$, and Ce(IV) complexes of Cyc1 exhibited no proteolytic properties. Incubation of BSA, $\gamma$-globulin, elongation factor $\mathrm{P}$, gelatin $\mathrm{A}$, and gelatin $\mathrm{B}$ with $\mathrm{Cu}(\mathrm{II})$ and $\mathrm{Co}(\mathrm{III})$ complex of Cyc1 did not result in the cleavage of these proteins. No changes in $\mathrm{Mb}$ structure were observed in experiments with $\mathrm{CuCl}_{2}, \mathrm{Cu}(\mathrm{II}) \mathrm{Cyc}$, and $\mathrm{Co}(\mathrm{II}) \mathrm{Cyc}$. The $\mathrm{Cu}(\mathrm{II})$ and $\mathrm{Co}(\mathrm{III})$ complexes of Cyc1 hydrolyzed up to 2.5 or $6 \mathrm{~mol}$ equivalents of $\mathrm{Mb}$, respectively, indicating a catalytic nature of the studied reaction. The $\mathrm{pH}$ dependence of $k_{\mathrm{cat}}$ was bell-shaped, with the optimum at the physiological $\mathrm{pH}$. The reaction was not affected by aerobic/anerobic conditions. Also the 
<smiles>CCCN(CCNC(=O)CC1CCNCCNCCNCC1)C(=O)Cn1cnc2c(N)nc(N)nc21</smiles>

Fig. 9. The structure of the most active cyclen derivative of peptide nucleic acid, used in the form of a $\mathrm{Cu}(\mathrm{II})$ or $\mathrm{Co}(\mathrm{III})$ complex as an artificial protease for myoglobin hydrolysis [69].

successful $\mathrm{N}$-terminal sequencing of reaction products suggested a hydrolytic origin of the process [69].

The ability of cyclen to bind $\mathrm{Cu}$ (II) tightly was also used by Yoo and co-workers to synthesize artificial metalloproteases containing multinuclear metal centers [70]. The idea of multinuclear compounds was inspired by naturally occurring metalloenzymes containing two or more metal ions in active sites. The aim of this approach was not only to cleave proteins but also to recognize and bind at their specific regions. The catalytic module containing $\mathrm{Cu}$ (II) cyclen complexes was attached to a derivatized crosslinked polystyrene support (PS). The structures of studied compounds are shown in Fig. 10.

The tetrameric compound ( $\mathrm{Cu}(\mathrm{II}) \mathrm{C}$-PS) was much more effective than the dimeric ( $\mathrm{Cu}(\mathrm{II}) \mathrm{B}-\mathrm{PS})$ and the mononuclear $(\mathrm{Cu}(\mathrm{II}) \mathrm{A}-\mathrm{PS})$. For example, the Mb hydrolysis half-time by $\mathrm{Cu}(\mathrm{II}) \mathrm{B}-\mathrm{PS}$ at $\mathrm{pH} 9.0$ and $50^{\circ} \mathrm{C}$ was almost 3 times lower (faster reaction) than for $\mathrm{Mb}$ hydrolysis by $\mathrm{Cu}(\mathrm{II}) \mathrm{C}$-PS at the same $\mathrm{pH}$ and a lower temperature $37^{\circ} \mathrm{C}$ ( 2 and $0.7 \mathrm{~h}$ respectively). The catalytic efficiency increased a hundred times, due to the increase of the catalytic group density in the module from the mono- to the tetranuclear compound. The pH 9.0 was chosen as optimal for this reaction from the $k_{\text {cat }}$

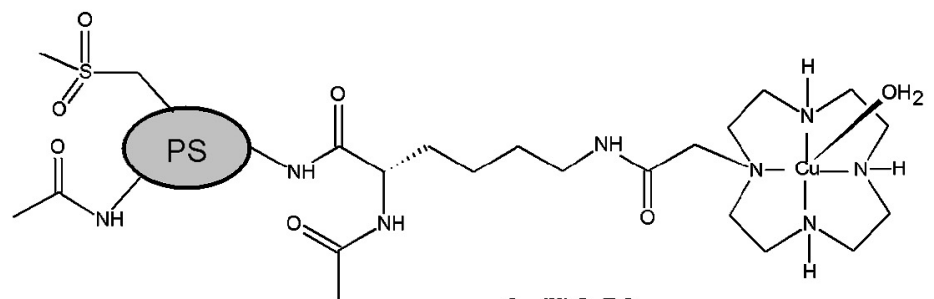

Cu(II)A-PS

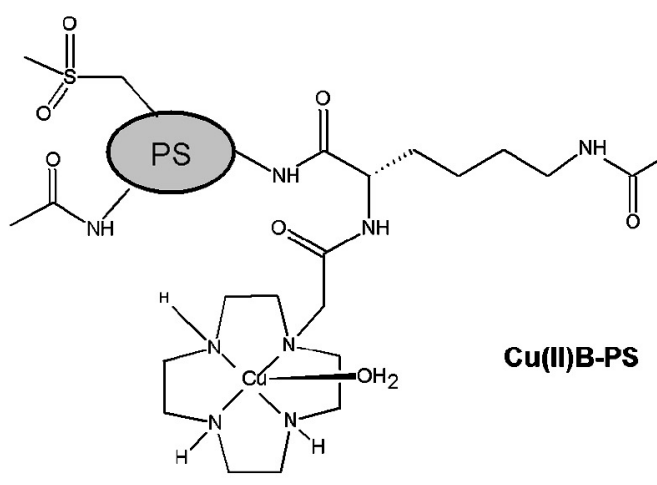

$\mathrm{pH}$ dependence and catalytic efficiency plots. Two initial cleavage sites, Gln91-Ser92 and Ala94-Thr95, were found for Mb hydrolysis by $\mathrm{Cu}(\mathrm{II}) \mathrm{B}-\mathrm{PS}$, which agrees with the length of the linkage connecting two catalytic moieties of $\mathrm{Cu}(\mathrm{II}) \mathrm{B}-\mathrm{PS}$. The heme carboxylate group was proposed as the anchoring site for the catalytic compounds. No cleavage was observed for a 3 days incubation of $\mathrm{Mb}$ with $\mathrm{Cu}(\mathrm{II}) \mathrm{B}$ or $\mathrm{Cu}(\mathrm{II}) \mathrm{C}$ not immobilized at PS at $\mathrm{pH} 7-9$ and $50^{\circ} \mathrm{C}$. BSA and bovine serum $\gamma$-globulin were not affected by the studied compounds within $24 \mathrm{~h}$ incubations at $\mathrm{pH} \mathrm{7-10}$ and $50^{\circ} \mathrm{C}$. An added aldehyde group was used to extend the range of proteins susceptible to hydrolysis by $\mathrm{Cu}(\mathrm{II}) /$ cyclen complexes immobilized on polystyrene [71]. It can reversibly form imine bonds with $\varepsilon$-amino groups of Lys side chains presented on the surface of proteins. Two types of compounds, $\mathrm{Cu}$ (II)AA-PS and $\mathrm{Cu}(\mathrm{II}) \mathrm{BB}-\mathrm{PS}$, were used in that study with corresponding controls devoid of the aldehyde group, $\mathrm{Cu}(\mathrm{II}) \mathrm{AA}^{*}$-PS and $\mathrm{Cu}(\mathrm{II}) \mathrm{BB}^{*}$-PS, Fig. 11.

All six studied proteins (Mb, $\gamma$-globulin, BSA, HSA, HEWL, and ovalbumin) were cleaved by $\mathrm{Cu}(\mathrm{II}) \mathrm{AA}-\mathrm{PS}$ and $\mathrm{Cu}(\mathrm{II}) \mathrm{BB}-\mathrm{PS}$. The half times of these reactions were in the range of 4.6-19 min at $\mathrm{pH} 9.0$ and $50^{\circ} \mathrm{C}$. The catalytic efficiency of $\mathrm{Mb}$ hydrolysis by reagents carrying the aldehyde group was 20-80 times higher than for $\mathrm{Cu}$ (II)B-PS. The reaction in the presence of control compounds without the aldehyde group was much slower.

For $\mathrm{Cu}(\mathrm{II}) \mathrm{AA}-\mathrm{PS}$ seven $\mathrm{Mb}$ cleaveage products were identified, whereas for $\mathrm{Cu}$ (II)BB-PS there were five of them. All contained a Ser or Thr at the C-terminus of the hydrolyzed bond. The Gln91-Ser92 and Ala94-Thr95 peptide bonds were amongst the main cleavage sites in Mb, similarly to the hydrolysis of Mb by $\mathrm{Cu}$ (II)B-PS. For other proteins, the presence of Ser/Thr adjacent to the cleaved peptide bond was not so frequent as for $\mathrm{Mb}$, and was equal to the incidence of Cys/Met or Gly/Ala residues [71].

Suh and co-workers proved that the hydrolytic activity of $\mathrm{Co}(\mathrm{III}) / \mathrm{Cu}$ (II) complexes of cyclen could be increased by the replacement of one cyclen nitrogen atoms with an oxygen $[72,73]$. The catalytic efficiency of the 1-oxa-4,7,10-triazacyclododecane $\mathrm{Co}$ (III) complex (Co(III)-oxacyclen) was 4-14 times higher than those observed for Co(III)-cyclen complexes toward BSA, HEWL, Mb, and bovine serum $\gamma$-globulin. For the $\mathrm{Cu}(\mathrm{II})$-oxacyclen complexes,

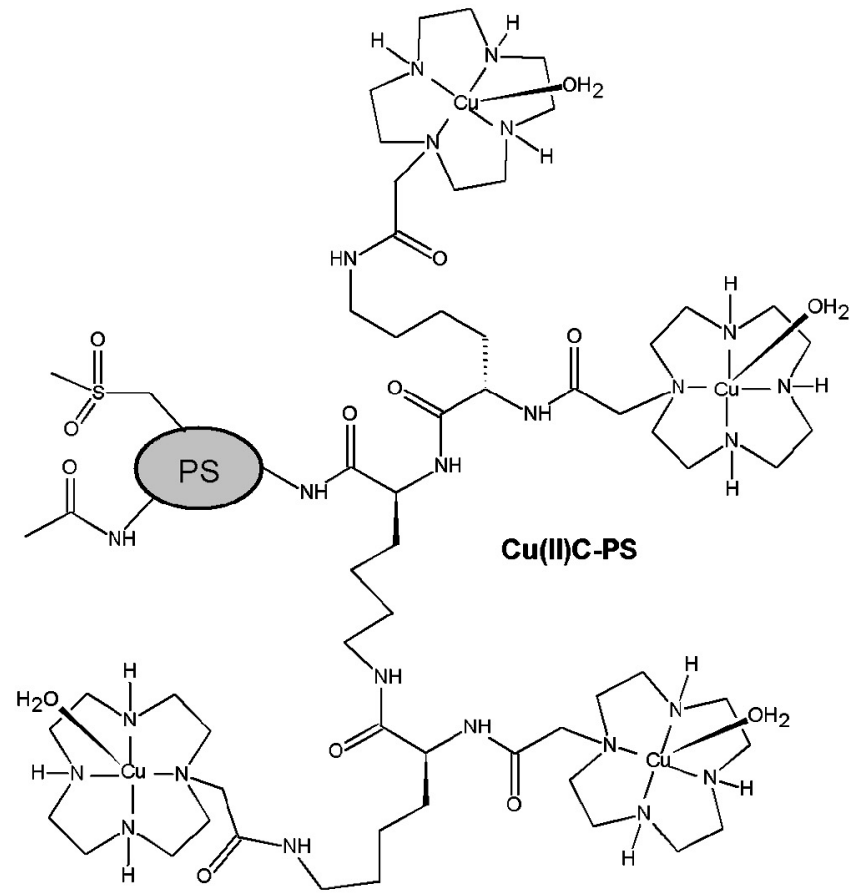

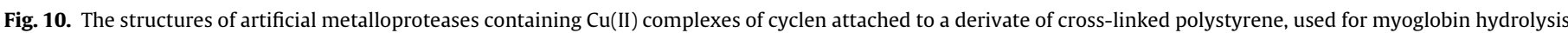
[70]. 


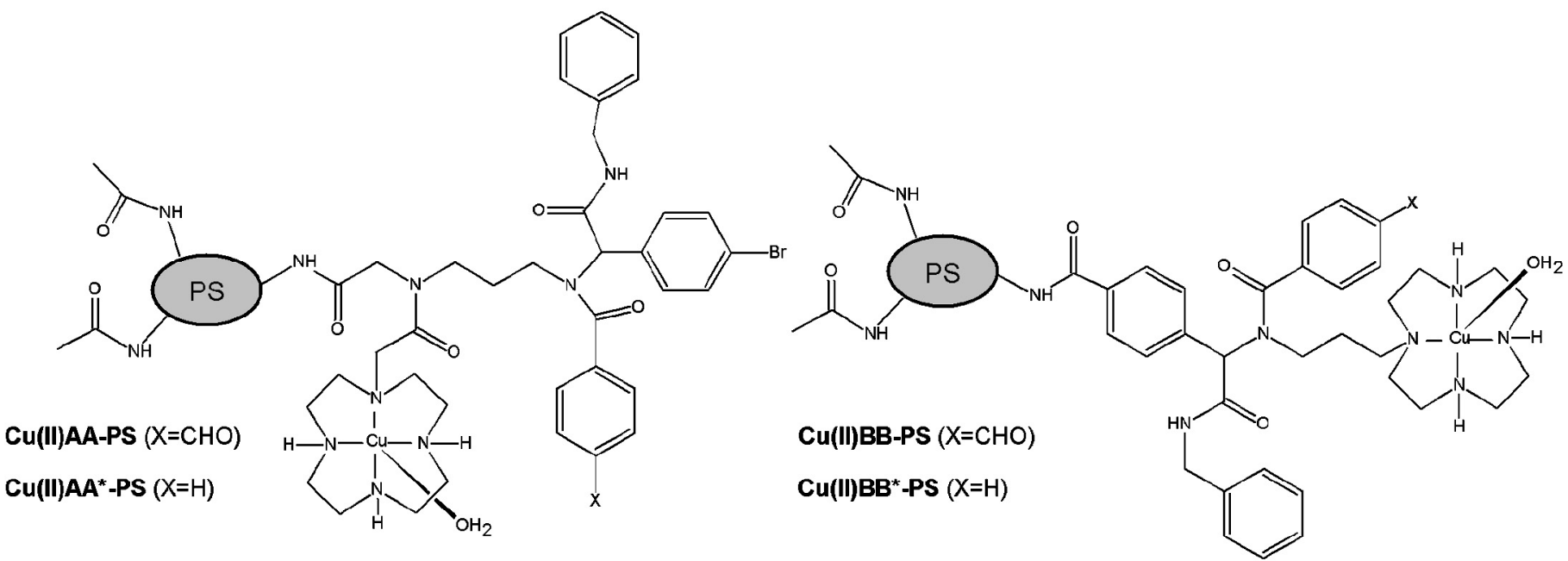

Fig. 11. The structures of artificial metalloproteases containing a cyclen $\mathrm{Cu}(\mathrm{II})$ complex and the aldehyde group attached to a derivate of cross-linked polystyrene [71].

the catalytic efficiencies similar or higher than those for $\mathrm{Co}(\mathrm{III})$ oxacyclen complexes were established. The differences between $\mathrm{Co}(\mathrm{III}) / \mathrm{Cu}$ (II) cyclen and oxacyclen complexes are associated with the higher Lewis acidity in oxacyclen compounds or with the steric effects.

A DFT study revealed that the best location for the nitrogen/oxygen substitution with respect to hydrolytic properties of oxacyclen should be position 10 rather than 1, used in the previously described study. The energy barrier for the hydrolysis is lower by $1.1 \mathrm{kcal} / \mathrm{mol}$ and $3.8 \mathrm{kcal} / \mathrm{mol}$ for the compound with the oxygen at position 10 and 4 respectively, compared to the compound with the oxygen at position 1 [74].

The oxidized insulin chain B, a 30 amino acid polypeptide, was hydrolyzed by $\mathrm{Cu}(\mathrm{II})$ [75,76] and $\mathrm{Zn}(\mathrm{II})$ [77] compounds. These experiments were carried out at a very low $\mathrm{pH} 2.5$ and a temperature of $37-40^{\circ} \mathrm{C}$. The reason for choosing such very acidic conditions was not provided in the paper. It seems that it could have been dictated by a need for a direct comparison between $\mathrm{Cu}(\mathrm{II}) / \mathrm{Zn}(\mathrm{II})$-assisted hydrolysis and that caused by $\mathrm{Pd}(\mathrm{II}) / \mathrm{Pt}(\mathrm{II})$ compounds. It is also possible that the authors wanted to avoid a coordination of $\mathrm{Cu}$ (II) by amide nitrogen, unfavorable for Lewis acid mechanisms of peptide bond cleavage. One cleavage site was observed for hydrolysis of oxidized insulin chain $\mathrm{B}$ by $\mathrm{CuCl}_{2}$, Gly8-Ser9 [75]. The application of $\left[\mathrm{CuL}\left(\mathrm{H}_{2} \mathrm{O}\right)\right]^{2+}$, where $\mathrm{L}$ is 2-[bis(2-aminoethyl)amino]ethanol resulted in two additional peptide bonds being hydrolyzed, Asn3-Gln4 and Phe1-Val2 [76]. The reaction with $\mathrm{ZnCl}_{2}$ resulted in the hydrolysis of Asn3-Gln4, His5-Leu6, Gly8-Ser9, and Glu21-Arg22 bonds [77].

\subsubsection{Oxoanions and POMs}

Hydrolytic properties of oxomolybdate(VI) toward HEWL [78] were studied as a follow-up of the successful cleavage of dipeptides by this compound [19]. Incubation of HEWL with oxomolybdate(VI) over several days at $\mathrm{pH} 5.0$ and $60^{\circ} \mathrm{C}$ resulted in the hydrolysis at four peptide bonds, Asp18-Asn19, Asp48-Gly49, Asp52-Trp53, and Asp101-Gly102. Interestingly, the Asp residue occurred at the $\mathrm{N}$-terminus of all identified cleavage sites. The studies on dipeptides showed the preference of oxomolybdate(VI) toward Xaa-Ser sequences, but they were performed at a higher $\mathrm{pH}, 7.0$. The coordination of molybdate(VI) by the Asp side chain carboxylate, as well as the formation of a succinimidyl bond between the amide nitrogen and the carboxylic carbon of the Asp side chain at high $\mathrm{pH}$ could decrease the hydrolysis rate under basic conditions. The HEWL hydrolysis occurred also at $\mathrm{pH} 7.0$, but was much slower than at pH 5.0. The mechanisms of Asp-Xaa hydrolysis, confirmed in dipeptide experiments are similar to that reported elsewhere for Xaa-Ser, Fig. 12.

In both of them the side chain hydroxyl group (Ser or Asp) attacks the carbonyl of the peptide bond adjacent to the Ser/Asp according to the $\mathrm{N} \rightarrow \mathrm{O}$ acyl rearrangement process, while this group is polarized by the metal compound. The Asp-Xaa bond is labile at high temperatures even without a catalyst or a metal ion assistance. The half-times of uncatalyzed hydrolysis of Asp-Gly dipeptide are 115 and $229 \mathrm{~h}$ at $60^{\circ} \mathrm{C}$ and $\mathrm{pH} 5.0$ and 7.0, respectively. The addition of oxomolybdate( $\mathrm{VI})$ accelerated this reaction by 1.4 times at $\mathrm{pH}$ 5.0. No significant changes were observed at $\mathrm{pH}$ 7.0. A three day incubation of HEWL without the metal species under the same condition indicated that the protein was stable during experiments [78].

The high selectivity for Asp-Xaa peptide bonds was also detected in the Mb hydrolysis by a $\mathrm{Zr}(\mathrm{IV})$-substituted POM. The most effective reaction was performed at $\mathrm{pH} 5.0$ and $60^{\circ} \mathrm{C}$ in the presence of 2:2 $\mathrm{Zr}(\mathrm{IV})-\mathrm{Kg} \mathrm{POM}$, described in Section 2.1.4. After three days, $40 \%$ of $\mathrm{Mb}$ was hydrolyzed by $2: 2 \mathrm{Zr}(\mathrm{IV})-$ $\mathrm{Kg}$ POM. All six detected cleavage sites have the Asp residue at the N-terminus of the hydrolyzed peptide bond: Asp4-Gly5, Asp20-Ile21, Asp44-Lys45, Asp60-Leu61, Asp126-Ala127. The peptide bonds at two other Asp residues of Mb (Asp109-Ala110 and Asp122-Phe123) were not susceptible to the reaction, because of unfavorable surface properties for the interaction with POM and the competition between adjacent Asp122 and Asp126 residues for the cleavage agent binding. A similar selectivity was not observed for Glu residues. Despite the presence of a carboxyl group capable to bind oxophilic $\mathrm{Zr}(\mathrm{IV})$, Glu forms a six-membered intermediate, less stable than the five-membered one with Asp [79].

HEWL was also a model protein for the hydrolysis by a $\mathrm{Ce}(\mathrm{IV})$ Keggin POM 1:2 Ce(IV)-Kg POM. Experiments carried out at $\mathrm{pH} 7.4$ and $37^{\circ} \mathrm{C}$ showed that the studied compound cleaved the Trp28-Val29 peptide bond, localized in the $\alpha$-helical structure, almost immediately. The hydrolysis at the second site, Asn44-Arg45, was observed later, after about $9 \mathrm{~h}$ from the beginning of the reaction. In contrast to peptides, HEWL was not hydrolyzed by $\mathrm{Ce}(\mathrm{IV})$ salts, $\mathrm{Ce}\left(\mathrm{NH}_{4}\right)_{2}\left(\mathrm{NO}_{3}\right)_{6} \cdot 4 \mathrm{H}_{2} \mathrm{O}$ and $\mathrm{Ce}\left(\mathrm{NH}_{4}\right)_{2}\left(\mathrm{SO}_{4}\right)_{6} \cdot 4 \mathrm{H}_{2} \mathrm{O}$. No HEWL decomposition was noticed in the presence of POM without Ce(IV). These observations suggest that both the structure provided by the POM and the presence of $\mathrm{Ce}(\mathrm{IV})$ are necessary for protein hydrolysis. The properties of proteins, especially the local surface charge, are important for a successful reaction. The advantage of POM is based on an proteinPOM electrostatic interaction. The negatively charged $1: 2 \mathrm{Ce}(\mathrm{IV})-\mathrm{Kg}$ 


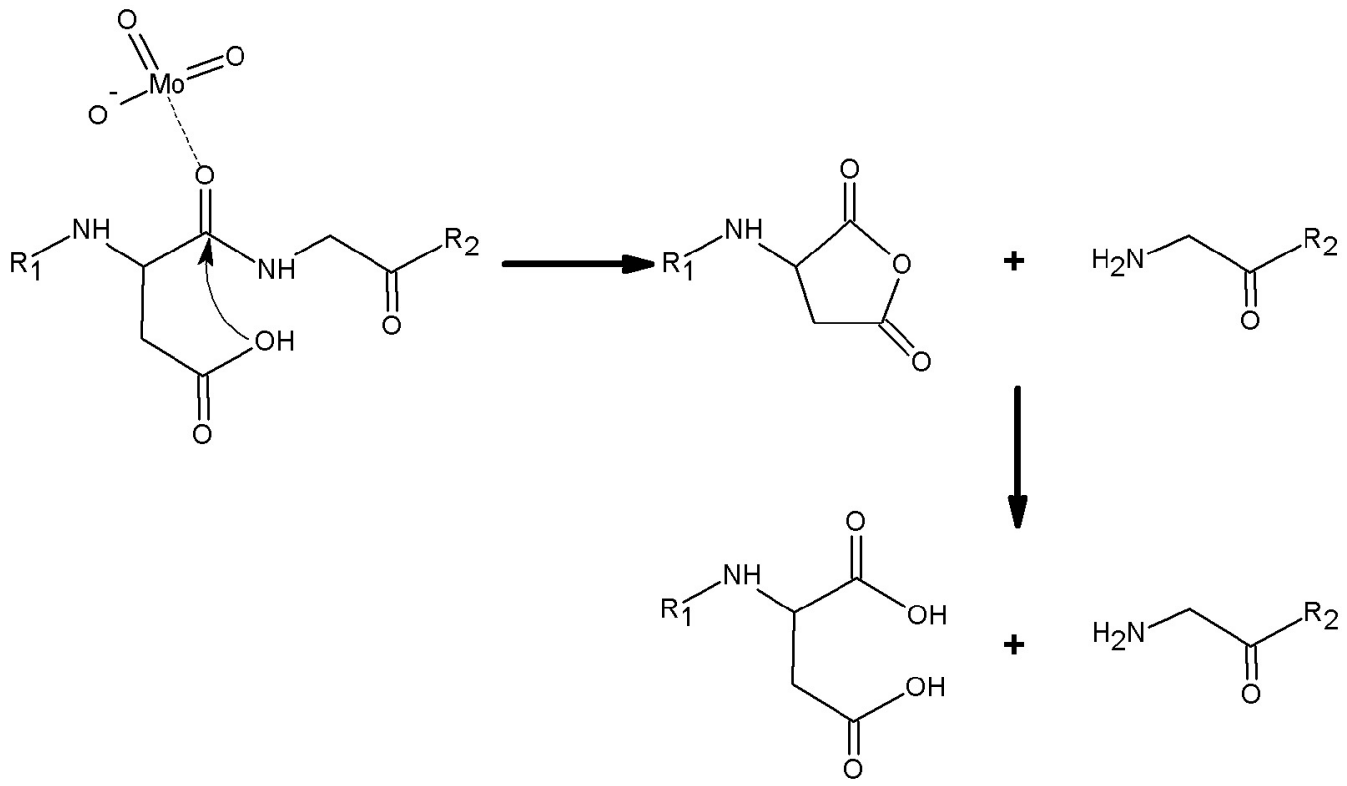

Fig. 12. Mechanism of hydrolysis of Asp-Xaa bond assisted by oxomolybdate(VI) [78].

POM can facilitate the interaction with HEWL, which is positively charged under the experimental conditions. Another protein, $\alpha$-lactalbumin, despite a three-dimensional structure almost identical to HEWL, was not susceptible to Ce(IV)-assisted hydrolysis due to its negatively charged surface. The electrostatic interaction between the positively charged area of the protein surface in the proximity of Trp28-Val29 and the negatively charged POM surface was responsible for such fast cleavage of this peptide bond. The hydrolysis at the second cleavage site Asn44-Arg45 was mostly directed by the propensity of $\mathrm{Ce}(\mathrm{IV})$ to interact with the side chain carboxyl groups. The replacement of $\mathrm{Ce}(\mathrm{IV})$ with $\mathrm{Zr}(\mathrm{IV})$ or $\mathrm{Hf}(\mathrm{IV})$ gave the same pattern of hydrolysis, but lowered the reaction rates [32]. A more detailed study regarding the nature of the interaction of proteins and metal-substituted POMs was conducted using HSA and different types of Zr(IV)-substituted POMs: (i) Wells-Dawsontype POMs, 1:2 Zr(IV)-WD POM and 4:2 Zr(IV)-WD POM, previously described in Section 2.1.4; (ii) Keggin type POMs, the previously described 2:2 $\mathrm{Zr}(\mathrm{IV})-\mathrm{Kg}$ POM and its analog 1:2 $\mathrm{Zr}(\mathrm{IV})-\mathrm{Kg}$ POM $\left(\mathrm{Et}_{2} \mathrm{NH}_{2}\right)_{10}\left[\mathrm{Zr}\left(\mathrm{PW}_{11} \mathrm{O}_{39}\right)_{2}\right] \cdot 7 \mathrm{H}_{2} \mathrm{O}$; (iii) a Lindqvist-type POM, 2:2 $\mathrm{Zr}(\mathrm{IV})-\mathrm{Ld} \mathrm{POM}\left(n \mathrm{Bu}_{4} \mathrm{~N}\right)_{6}\left[\left\{\mathrm{~W}_{5} \mathrm{O}_{18} \mathrm{Zr}\left(\mu-\mathrm{OH}_{2}\right)\right\}\right] \cdot 2 \mathrm{H}_{2} \mathrm{O}$.

The most effective $\mathrm{Zr}(\mathrm{IV})$ compounds were Wells-Dawson POMs, 1:2 Zr(IV)-WD POM and 4:2 Zr(IV)-WD POM, with 75 and $50 \%$ conversion degrees after $48 \mathrm{~h}$, at $\mathrm{pH} 7.4$ and $60^{\circ} \mathrm{C}$. Less than $35 \%$ of HSA was hydrolyzed under the same conditions by other POMs. The significant role of the incorporation of $\mathrm{Zr}(\mathrm{IV})$ into POM for metal-supported hydrolysis was proved by the absence of reactivity or a very low reaction yield for $\mathrm{ZrCl}_{4}$ or a POM without $\mathrm{Zr}(\mathrm{IV})$. The cleavage sites of HSA hydrolysis by $1: 2 \mathrm{Zr}(\mathrm{IV})-\mathrm{WD}$ POM were Arg114-Leu115, Ala257-Asp258, Lys313-Asp314, and Cys392-Glu393. All of them are located in positively charged areas of the protein surface, which can attract the POM electrostatically. Additionally, the last three cleaved peptide bonds contain C-terminal carboxylic acids, which enhance the possibility of anchoring the $\mathrm{Zr}(\mathrm{IV})$ ion. The comparison of the hydrolysis yield and the charge of POM, metal ion, and a metal substituted POM revealed that the POM charge was the most important factor in the HSA hydrolysis. The more negative the POM charge, the higher the yield of HSA hydrolysis [80].

Oxidized insulin chain B was chosen as a next model for hydrolysis by $\mathrm{Zr}(\mathrm{IV})$-substituted Wells-Dawson POM [81]. Four cleavage sites were observed for reaction performed at $37^{\circ} \mathrm{C}$ (Phe1-Val2, Gln4-His5, Leu6-Cys $\left(\mathrm{SO}_{3} \mathrm{H}\right) 7$, Gly8-Ser9) and five at $60{ }^{\circ} \mathrm{C}$ (additionally Gly20-Glu21). For another $\mathrm{Zr}(\mathrm{IV})$ compound, $\mathrm{Zr}$ (IV)-substituted 4,13-diaza-18-crown-6, 13 cleavage sites were detected after an $8 \mathrm{~h}$ incubation at $\mathrm{pH} 7.0$ and $60^{\circ} \mathrm{C}$ [82]. The major ones were: Gly8-Ser9, Gly20-Glu21, Ser9-His10, Cys $\left(\mathrm{SO}_{3} \mathrm{H}\right) 7-\mathrm{Gly} 8$, and $\mathrm{Cys}\left(\mathrm{SO}_{3} \mathrm{H}\right) 19-\mathrm{Gly} 20$. The half time of this hydrolysis was about $8 \mathrm{~h}$. It was much (17 times) faster than that performed in the presence $\mathrm{ZrCl}_{4}$, but more than five times slower than for 1:2 Zr(IV)-WD POM.

\subsection{3. $P d(I I)$ and $P t(I I)$ complexes}

$\mathrm{Pd}(\mathrm{II})$ complexes performed the cleavage of cytochrome $\mathrm{c}, \mathrm{Mb}$, ubiquitin, $\beta$-casein and BSA $[47,83,84]$. Cytochrome $c$ was cleaved

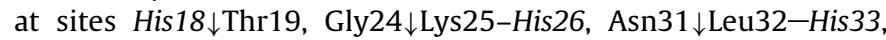
Thr63 $\downarrow$ Leu64-Met65, Thr78 $\downarrow$ Lys79-Met80 (metal anchoring residues in italics, hydrolysis sited marked with $\downarrow$ ) $[47,85]$. Ubiquitin was susceptible to hydrolysis by $\operatorname{Pd}(\mathrm{II})$ at site Thr66 $\downarrow$ Leu67-His68 with and without the presence of a detergent (CHAPS or Zwittergent 3-14) and at several other sites in the presence of CHAPS or Zwittergent 3-14 [47,84]. Mb was cleaved by $\mathrm{Pd}(\mathrm{II})$ at 13 sites, in the vicinity of methionine, histidine, and arginine residues [83]. $\beta$-casein, a 224-amino-acid protein had 24 scissile peptide bonds [84]. BSA (607 amino acids) was cleaved at 80 sites in the presence of CHAPS and Zwittergent 3-14 [84].

The oxidized insulin chain $\mathrm{B}$ underwent the hydrolysis caused by cis-[Pd-(en) $\left.\mathrm{Cl}_{2}\right]$ or cis-[Pd-dtco-3-OH) $\left.\mathrm{Cl}_{2}\right]$ only in the presence of urea. The incubation of the peptide with $\mathrm{Pd}(\mathrm{II})$ complexes at $\mathrm{pH}$ 2.5 and $40^{\circ} \mathrm{C}$ over 10 days in the absence of a denaturing agent did not result in the hydrolysis of the peptide. $\mathrm{Pd}(\mathrm{II})$ was bound to insulin only via the terminal amino group under these conditions. The protein denaturation caused by urea allowed $\mathrm{Pd}(\mathrm{II})$ to bind also at His5 and His 10, leading to the hydrolysis of two peptide bonds in the vicinity of these anchoring residues, Leu6-Cys 7 and Gly8-Ser9. Neither the type of Pd(II) complexes used, nor the $\mathrm{pH}$ of the reaction affected the hydrolytic rate of cleavage [86]. However, Milović and Kostić showed that incubation of insulin chain B with cis- $\left[\mathrm{Pd}-(\mathrm{en})\left(\mathrm{H}_{2} \mathrm{O}\right)_{2}\right]^{2+}$ at $\mathrm{pH} 2.0$ and $60^{\circ} \mathrm{C}$ resulted in the hydrolysis of Asn3-Gln4 and Gly8-Ser9 peptides bonds although no urea was present in the reaction mixture [47]. The differences between the 
reactivity of cis-[Pd(en) $\left.\mathrm{Cl}_{2}\right]$ and cis-[Pd(en $\left.)\left(\mathrm{H}_{2} \mathrm{O}\right)_{2}\right]^{2+}$ were probably caused by a faster ligand exchange in cis- $\left[\mathrm{Pd}(\mathrm{en})\left(\mathrm{H}_{2} \mathrm{O}\right)_{2}\right]^{2+}$, compared to cis-[Pd(en $\left.) \mathrm{Cl}_{2}\right]$. For cis-[Pt(en $\left.)\left(\mathrm{H}_{2} \mathrm{O}\right)_{2}\right]^{2+}$ only one cleavage site, His10-Leu11 was observed in the oxidized insulin $\mathrm{B}$ chain after 11 days of incubation at $\mathrm{pH} 2.5$ and $40^{\circ} \mathrm{C}$. No denaturing agents were used in this experiment [86].

\subsection{4. $\mathrm{Ca}(\mathrm{II})$ dependent autocleavage domains}

Metal dependent cleavage of autocatalytic protein domains, while very different from most of the metal based reactions described in this review, nevertheless belong to the category of metal-dependent hydrolytic reactions. The best characterized example comes from a domain present in a microorganism, Vibrio coralliilyticus ATCC BAA- 450 . This domain, originally dubbed DUF1521 (the acronym originating from the phrase "domain of unknown function") exhibits metal ion-inducible autocleavage activity in the presence of a range of divalent metal ions. $\mathrm{Ca}$ (II) and $\mathrm{Mn}(\mathrm{II})$ ions exhibited the highest activity, followed by $\mathrm{Cd}(\mathrm{II})$, $\mathrm{Co}(\mathrm{II})$, and $\mathrm{Ni}(\mathrm{II})$, with a weak reactivity from $\mathrm{Mg}(\mathrm{II}), \mathrm{Cu}(\mathrm{II})$, and $\mathrm{Zn}(\mathrm{II})$ ions [86]. The reaction mechanism has not been determined so far, but most likely has a structural basis (the cleavage occurring at the Asp-Pro bond does not seem to be metalcatalyzed directly), because the whole domain, ca. 140 amino acid residues is necessarily required for the process [86,87]. Several analogous domains cleaving the Asp-Pro bond are known from other microorganisms, but these are specifically $\mathrm{Ca}$ (II) dependent $[88,89]$.

\section{The non-Lewis acid reaction mechanisms based on the $\mathbf{N} \rightarrow \mathbf{O}$ rearrangement}

All the reactions described above were confirmed or presumed to employ Lewis acid properties of metal ions. In some cases the acceleration of hydrolysis of peptide bonds preceding a Ser or Thr residue was observed. It was commonly attributed to a mixed reaction mechanism with a participation of the $\mathrm{N} \rightarrow \mathrm{O}$ rearrangement of the acyl moiety (case (iii) in Fig. 2). In this section we describe three instances of reactions that are based solely or largely on the $\mathrm{N} \rightarrow \mathrm{O}$ rearrangement, and do not employ Lewis acid properties of respective metal ions. In all cases the hydrolysis reactions are assisted by those metal ions which can effectively deprotonate and bind to multiple peptide nitrogen atoms and, opposed to some systems presented above, such binding mode is prerequisite for the hydrolysis.

\subsection{Diamminedichloroplatinum(II) hydrolysis of Ser-Met bond}

The Lewis acid reactivity of diamminedichloroplatinum(II) (the active substance of the antitumor drug cisplatin) and similar complexes was described above in Section 2.2.3. The $\mathrm{pH}$ dependence of this reactivity, common for all $\mathrm{Pd}(\mathrm{II})$ and $\mathrm{Pt}(\mathrm{II})$-assisted reactions, exhibited a sharp decrease of the rate with the $\mathrm{pH}$ increase, due to the replacement of water molecules in the first coordination sphere by peptidic ligands and/or by the formation of hydroxobridged oligomers. In contrast, the $\mathrm{pH}$ dependence of the reaction of diamminedichloroplatinum(II) with the Ac-Ser-Met dipeptide, after passing through a minimum at $\mathrm{pH} 4.4$, increased again, reaching a plateau at $\mathrm{pH}$ 7.5-9.5. The $\mathrm{Pt}(\mathrm{II})$ complex with the reaction substrate was fully saturated by substrate donor atoms (Met thioeter and two preceding peptide nitrogens) and the remaining ammine ligand. The reaction mechanism determined for this process has a pure $\mathrm{N} \rightarrow \mathrm{O}$ acyl rearrangement character, with Ser hydroxyl serving as a nucleophile [90]. Unfortunately, this interesting line of research was not continued.

\section{2. $\mathrm{Cu}(\mathrm{II})$ hydrolysis of Thr-His and Ser-His bonds}

Allen and Campbell were first to report a hydrolysis reaction assisted by a metal ion, which did not rely on its Lewis acid properties. They reported the hydrolysis of a series of heptapeptide substrates by $\mathrm{Cu}(\mathrm{II})$ ions [91]. This work was inspired by their discovery of site specific degradation of an antibody upon storage in buffers containing a residual $\mathrm{Cu}(\mathrm{II})$ contamination [92]. The reaction was specific for the Xaa-(Ser/Thr) bond within -Xaa-(Ser/Thr)-His-Zaa sequences, with reaction rates influenced by Xaa and Zaa substitutions and a strong temperature dependence. Although most of the work was done for Thr containing peptides, the Ser substituted peptide was hydrolyzed 1.8 times faster. The process, very slow at low $\mathrm{pH}$ and room temperature, was accelerated very significantly at $\mathrm{pH} \sim 8$ and temperatures above $50^{\circ} \mathrm{C}$. The mechanism proposed to account for these properties involved the $\mathrm{N} \rightarrow \mathrm{O}$ acyl rearrangement, with the metal ion playing the role of a proton in coordinating the nitrogen atom of the hydrolyzed amide bond. However, the traces of hydrolysis product (1-2\% of the yield) were still detected upon the replacement of Thr with Ala. Although not discussed explicitly by the authors, the $\mathrm{pH}$ dependence of the reaction clearly suggest that a three-nitrogen (3N) $\mathrm{Cu}(\mathrm{II})$ complex with the metal ion coordinated to His imidazole, and two preceding peptide nitrogens, provided by Xaa-Thr and Thr-His bonds was the hydrolytic species. A very slow hydrolysis of the Xaa-Ala bond is thus indicative of an additional Lewis acid contribution to the mechanism, with the participation of an activated water/hydroxyl molecule provided by the fourth coordination site at the $\mathrm{Cu}(\mathrm{II})$ ion.

\subsection{Peptide bond hydrolysis in four-coordinate square-planar complexes of peptides with transition metal ions}

The title reaction was discovered in the course of studies of interactions of $\mathrm{Ni}(\mathrm{II})$ ions with peptides derived from human histone sequences. During a $\mathrm{pH}$ titration of a model peptide Ac-Thr-Glu-Ser-His-His-Lys-am derived from the C-terminal tail of histone $\mathrm{H} 2 \mathrm{~A}$ a characteristic alternate pattern of bands in the visible range of $\mathrm{CD}$ spectra appeared at a weakly alkaline $\mathrm{pH}$. The intensity of this band gradually increased with the time of incubation [93]. Such a band pattern is characteristic for square planar complexes of peptides containing the N-terminal R1a-R2a-His sequence (so-called ATCUN or NTS motif), shown in Fig. 13A [94-97]. By looking at the original peptide sequence, we stated that this effect could only be explained by a cleavage of either of two peptide bonds flanking the Glu residue. Subsequent experiments revealed that the bond preceding Ser was the sole reaction target. This observation initiated a series of studies which resulted in the elucidation of the molecular mechanism of the reaction. Parallel studies, described in the next sections, provided chemical evidence indicating the relevance of this reaction in toxicology, and its applicability as a research tool in chemistry, biotechnology and cellular studies.
A

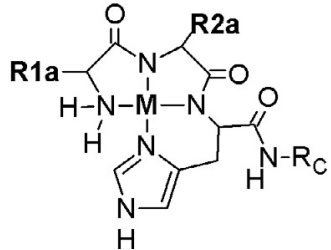

B

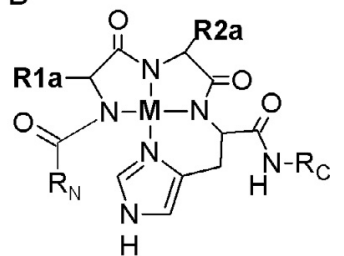

Fig. 13. (A) The ATCUN/NTS motif generated by N-terminal R1a-R2a-His sequences $\mathrm{R}_{\mathrm{C}}$ denotes the $\mathrm{C}$-terminal peptide chain. (B) The precursor motif, differing from the ATCUN/NTS motif by the non-terminal position of the R1a residue, which results in the peptide, rather than amine character of the R1a nitrogen donor. $\mathrm{R}_{\mathrm{N}}$ denotes the $\mathrm{N}$-terminal peptide chain, $\mathrm{M}$ denotes $\mathrm{Cu}(\mathrm{II}), \mathrm{Ni}(\mathrm{II})$, or $\mathrm{Pd}(\mathrm{II})$ [110]. 
The first follow-up study confirmed the specificity of hydrolysis for the same Glu-Ser bond in a 34-peptide covering the sequence of the C-terminal tail of the H2A protein, and for the whole $\mathrm{H} 2 \mathrm{~A}$ protein in the presence of $\mathrm{Ni}(\mathrm{II})$ ions at $\mathrm{pH} 7.4$ and $37^{\circ} \mathrm{C}$ [98]. In the same work, the metal specificity of the reaction was tested. The $\mathrm{Cu}(\mathrm{II})$ ions enabled the hydrolysis, but $\mathrm{Co}(\mathrm{II})$ and $\mathrm{Zn}(\mathrm{II})$ ions did not. Reaction rates for the short and long peptides and the whole protein differed several-fold, in favor of the 34-peptide, indicating that the reaction was sensitive to conformational/steric factors.

In the next two studies oligopeptides were used to investigate the sequence specificity of the $\mathrm{Ni}(\mathrm{II})$ reaction. A tentative $\mathrm{R}_{1}$-(Ser/Thr) -Xaa-His-Zaa- $\mathrm{R}_{2}$ sequences pattern was established, with $R_{1}$ being any amino acid sequence forming a peptide bond with the Ser or Thr residue, and $R_{2}$ being any amino acid sequence $[99,100]$. In these preliminary studies only a few Xaa and Zaa substitutions were investigated. However, the investigation of the $\mathrm{pH}$ dependence for the reaction of the Thr-substituted peptide suggested that the hydrolysis occurred solely in a complex species containing the $\mathrm{Ni}(\mathrm{II})$ ion coordinated to the His imidazole and three preceding peptide nitrogens (a four-nitrogen, in brief 4N complex, differing from the ATCUN/NTS motif by the amide in place of the amine nitrogen) [100] (see Fig. 13B, noting that R1a and R2a correspond to Ser/Thr, and Xaa, respectively). This result supported the view that the reaction might occur for any Xaa (except of Pro) and any Zaa substitution.

The next stage of investigations included a search for general correlations between the properties of these variable amino acids (Ser or Thr, Xaa, and Zaa) and the rate of hydrolysis. For this purpose, a peptide library, which contained 17 Xaa variants (except of Cys, Asp, and Glu) and 19 Zaa variants (except of Cys) was designed [101]. The exclusions were motivated by known abilities of side chains of these residues to bind $\mathrm{Ni}(\mathrm{II})$ ions, which would interfere with the $4 \mathrm{~N}$ binding mode of the $\mathrm{Ni}(\mathrm{II})$ ion presented in Fig. 13B, and by that would presumably prevent the hydrolysis [102-105].

The screening of this library confirmed the initial assumption. All tested peptides were susceptible to hydrolysis, but the reaction rates differed very significantly according to Xaa and, remarkably, also Zaa substitutions. The statistical analysis of reaction rate estimates (scores assigned on the basis of manual analysis of MALDI-TOF spectra, see [101] for details) revealed that bulky and hydrophobic residues in positions Xaa and Zaa accelerated the reaction very significantly, but their individual contributions to the rate were mutually independent. A preliminary molecular mechanics analysis indicated that the Xaa and Zaa residues were separated in space, being located on the opposite sites of the complex plane defined by the $\mathrm{Ni}(\mathrm{II})$ ion and its four nitrogen ligands. This finding explained the independence of contributions of these residues to the reaction rate, and indicated that steric crowding was a driving force of the reaction. Another observation of the library screening was that the Ser peptides were generally more susceptible to hydrolysis than the Thr peptides.

The library-based results were confirmed by detailed studies on seven peptides, predicted by the library analysis to have different reaction rates. In the course of these studies an intermediate reaction product (IP) was found, characterized with the same mass as the substrate. The IP was subsequently isolated for one of these peptides and identified to be an intramolecular ester by IR spectroscopy combined with the MS characterization [106]. Quantitative experiments performed in that study demonstrated that the reaction rate for the substrate decay/IP formation at any given $\mathrm{pH}$ value and $\mathrm{Ni}(\mathrm{II}) /$ peptide molar ratios was the product of the maximum reaction rate (determined at $\mathrm{pH} 11.6$ where the $4 \mathrm{~N}$ complex formation was $100 \%$ ) and the molar fraction of the $4 \mathrm{~N}$ complex. Therefore, this step of the reaction was $\mathrm{pH}$-independent, and thus did not include a water molecule activation. On the other hand, the decay of IP was strongly pH dependent, and was unmeasurably fast under strongly alkaline conditions. These results led to a proposal of the general reaction mechanism, shown in Fig. 14.

In this mechanism, the $4 \mathrm{~N} \mathrm{Ni(II)} \mathrm{complex} \mathrm{with} \mathrm{the} \mathrm{(Ser/Thr)-}$ Xaa-His sequence is formed initially, and then undergoes the $\mathrm{N} \rightarrow \mathrm{O}$ rearrangement. The $\mathrm{N}$-terminal $\mathrm{R}_{1}$ moiety migrates from the peptide bond to form an ester with the Ser/Thr hydroxyl group. This ester undergoes a spontaneous hydrolysis, yielding two final reaction products, the $\mathrm{R}_{1}$ peptide and the ATCUN/NTS Ni(II) complex with the rest of the molecule [106].

In several subsequent studies further details of this reaction mechanism were established. As predicted, Xaa substitutions with Glu or Asp resulted in poorly reactive oligopeptides [107]. The involvement of sterical crowding in the reaction mechanism was confirmed by another peptide library study, which showed that another aromatic residue upstream of Zaa was also beneficial for fast hydrolysis [108]. A study on a series of D-amino acid substituted peptides demonstrated that the stereochemistry of the $\mathrm{Ni}(\mathrm{II})$ binding Ser-Arg-His residues is another crucial feature of the reaction (Arg was the most efficient substitution in previous studies) [109]. The fastest hydrolysis was achieved for all-L or all- D isomers, while the mixed $\mathrm{D} / \mathrm{L}$ cases were much less reactive. No hydrolysis at all was found for peptides containing the D-Ser-L-Arg-L-His and LSer-D-Arg-D-His sequences. The $\mathrm{D} / \mathrm{L}$ substitutions did not affect the affinity of peptides for $\mathrm{Ni}(\mathrm{II})$ ions and retained the square-planar complex structure, but changed the up/down orientations of the side chains vs. the complex plane. Therefore, the hydrolytically optimal complex conformation requires the same orientation of all three $\mathrm{Ni}(\mathrm{II})$ binding residues.

Further experiments performed with the isolated intermediate ester in its metallated and metal-free forms yielded a better understanding of the role of $\mathrm{Ni}(\mathrm{II})$ ion in the reaction. In addition to its indirect structural role (imposing the strain on the hydrolysable peptide bond via the square-planar complex structure and by placing the Ser/Thr side chain in a position enabling its role as the acyl group acceptor), it has a direct function, destabilizing the $\mathrm{R}_{1}-\mathrm{Ser}$ peptide bond directly through its peptide nitrogen coordination. The engagement of the lone pair of the Ser/Thr amine by $\mathrm{Ni}(\mathrm{II})$ in the complex with the intermediate ester prevents its reversal to the thermodynamically more stable amide [110].

Comparative studies of model oligopeptides derived from proteins, and of their larger domains, or even whole proteins revealed that the hydrolysis rate may be increased or decreased, compared to a prediction based simply on Xaa and Zaa substitutions, as a result of a specific conformational context of the reactive complex provided by secondary protein structures (loops, helices and $\beta$-sheets [107,111,112].

The ability of the $\mathrm{Cu}(\mathrm{II})$ ion to convey the same reactivity was indicated previously [113]. A quantitative study demonstrated that the $\mathrm{Cu}$ (II) ion reacted according to the mechanism presented above for $\mathrm{Ni}$ (II), but much less eagerly (by one to two orders of magnitude, depending on the temperature) [111]. Preliminary experiments confirmed that $\mathrm{Pd}(\mathrm{II})$ ions, which form isostructural complexes with His-containing peptides, assist in the reaction, characterized by the same sequence specificity and intermediate product and similar rates. This observation thus definitely demonstrated that the formation of a $4 \mathrm{~N}$ square-planar complex is in Ser/Thr-Xaa-His sequences is both necessary and sufficient for the hydrolysis to occur $[114,115]$.

The $\mathrm{N} \rightarrow \mathrm{O}$ rearrangement at the core of the hydrolytic mechanism presented above is analogous to the $\mathrm{N} \rightarrow \mathrm{S}$ rearrangement yielding a thioester, and known e.g., for intein autocatalytic protein cleavage mechanism [116]. We examined this possibility for the peptides containing a Cys residue in place of Ser/Thr, but found that its thiol group binds the $\mathrm{Ni}(\mathrm{II})$ ion, thus preventing the acyl shift and forming an unproductive Ni(II) complex [117]. Instead, the Cys residue was able to replace the His residue as the $\mathrm{Ni}(\mathrm{II})$ 


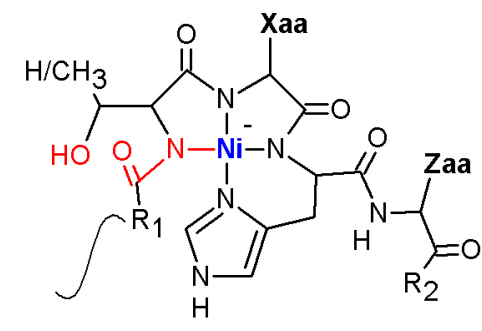

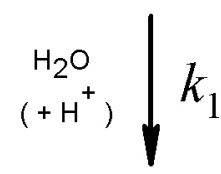

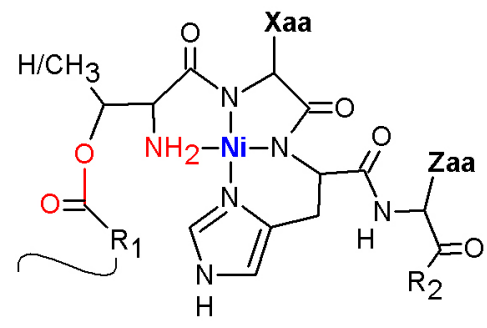<smiles>C[P+]#[P+]</smiles><smiles>[Y][C@H](C)[C@@H](C)O</smiles>

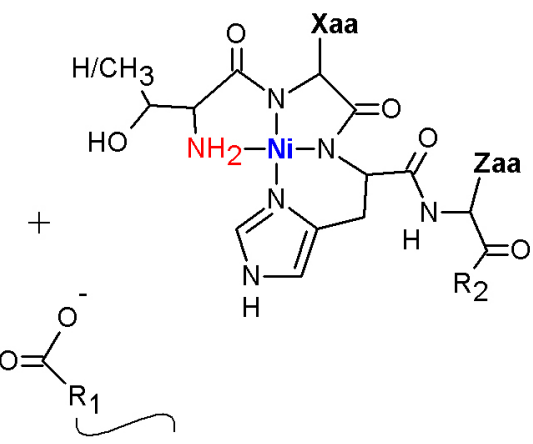<smiles>[R1]C(=O)N[C@H](C(=O)N[C@@H]([Y10])C(=O)N[C@@H](Cc1c[nH]cn1)C(=O)NC([Z10])C([R2])=O)C(O)CCC</smiles><smiles>[As]C1CC1</smiles><smiles>[R1]C(=O)OC(C)C(NC)C(=O)NC([Y10])C(=O)NC(Cc1c[nH]cn1)C(=O)NC([Z10])C([R2])=O</smiles>

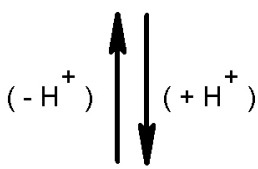<smiles>[R17]C(=O)OC(C)C([NH3+])C(=O)NC([Y10])C(=O)NC(Cc1c[nH]cn1)C(=O)NC([Z10])C([R2])=O</smiles><smiles>CC(C)(C)CC(C)(C)C</smiles>

Fig. 14. Mechanism of metal-substituted hydrolysis of peptide bond preceding Ser/Thr in (Ser/Thr)-Xaa-His-Zaa sequences [106,109].

binding residue, while with a somewhat lower efficacy of hydrolysis. Therefore, also the Ser/Thr-Xaa-Cys sequences are susceptible to the hydrolysis process. Further studies, currently in progress in our laboratory, are aimed at a full elucidation of the geometrical aspects of the $\mathrm{N} \rightarrow \mathrm{O}$ acyl rearrangement in the context of squareplanar complexes.

\section{Toxicological implications of metal assisted peptide bond hydrolysis}

Among the metal ion assisted processes, only the Ni(II) dependent peptide bond hydrolysis reaction has been considered as yet as a source of toxicity. $\mathrm{Ni}$ (II) ions are carcinogenic, especially upon the inhalatory exposure to poorly soluble particles containing $\mathrm{Ni}(\mathrm{II})$ compounds $[118,119]$. The contact or oral exposure to nickel metal or $\mathrm{Ni}(\mathrm{II})$ salts causes allergy in sensitized individuals. Also in this case, the soluble $\mathrm{Ni}$ (II) species are thought to be the toxic agents
[120,121]. Implants made of alloys containing nickel, such as stainless steel, give rise to both types of nickel toxicity by means of a slow release of $\mathrm{Ni}(\mathrm{II})$ ions [122,123].

$\mathrm{Ni}$ (II) related hydrolysis of peptide bonds may contribute to nickel toxicity by two chemically independent mechanisms. Protein fragmentation, a direct effect of hydrolysis, may have obvious consequences, such as loss of function, or acquiring alternative properties out of sync with cellular or tissue mechanisms. Stable $4 \mathrm{~N} \mathrm{Ni(II)} \mathrm{complexes} \mathrm{with} \mathrm{C-terminal} \mathrm{reaction} \mathrm{products} \mathrm{may}$ produce oxidative damage when exposed to hydrogen peroxide, which is an endogenous molecule. Such reactivity, proceeding via $\mathrm{Ni}(\mathrm{III})$ intermediates, was demonstrated for a range of synthetic complexes and for naturally occurring peptides bearing analogous N-terminal His-3 sequences [124-127]. It is very likely to contribute to molecular processes underlying $\mathrm{Ni}$ (II) carcinogenesis $[118,119,128]$, and perhaps also to nickel allergy [129]. 
A

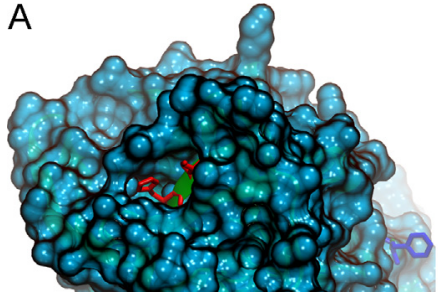

B

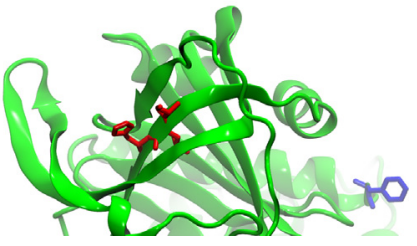

Fig. 15. The fragment of human $\alpha$-1-antitrypsin (AAT) containing the C-terminal cleavage site for $\mathrm{Ni}(\mathrm{II})$-assisted hydrolysis (marked red). The first residue of the known resolved structure, close to the $\mathrm{N}$-terminal disordered cleavage site, is shown as violet sticks. Two representations of the protein are shown, displaying the surface of the protein (A) and its secondary structure (B) [112].

An early study demonstrated that $\mathrm{Ni}(\mathrm{II})$ hydrolysis of histone $\mathrm{H} 2 \mathrm{~A}$ also occurred in $\mathrm{Ni}(\mathrm{II})$ exposed cell cultures [130]. This reaction occurred at high, but not cytotoxic exposures to $\mathrm{Ni}(\mathrm{II})$ salts. However, its toxicological consequences were not investigated at that time. Later research using model peptides indicated a range of potential targets for hydrolysis among human proteins. Perhaps the most striking case regards human $\mathrm{C} 2 \mathrm{H} 2$ zinc fingers. Nearly $25 \%$ (2922 out of 14,816 sequences catalogued in the Pfam 25.0 database as of 2010) contain Ser/Thr-Xaa-His sequence patterns. The susceptibility of these sequence patterns to hydrolysis was confirmed experimentally for two of these zinc finger peptides [107]. Further research confirmed this reactivity on the level of a whole zinc finger protein [131].

Annexins comprise another group of protein potentially susceptible to $\mathrm{Ni}(\mathrm{II})$ hydrolysis. As explained in the previous section, the conformational freedom of the Ser/Thr-Xaa-His sequence, which has to create a loop around the metal ion, is prerequisite for efficient hydrolysis. Such readily accessible reactive sites were identified in disordered regions or loop motifs on surfaces of annexins A1, A2, and $A 8$, and the susceptibility to hydrolysis of synthetic peptides representing these sequences was demonstrated experimentally [111]. A study in progress supported the occurrence of hydrolysis also on the level of recombinant annexins [132].

Human $\alpha$-1-antitrypsin (AAT) is an abundant serum protein serving as protector of lung tissue from the excessive activity of proteases. Lung AAT is inversely correlated with chronic obstructive pulmonary disease (COPD), a serious and often deadly condition in the aging population. Three hydrolysis sites were identified in AAT and cleavage at any of them abolished the activity of AAT in an additive manner. Also, Ni(II) ions bound to hydrolysis products demonstrated an ability to generate reactive oxygen species [112]. AAT was hydrolyzed not only by soluble $\mathrm{Ni}(\mathrm{II})$ salts, but also in the presence of $\mathrm{Ni}(\mathrm{II})$ oxide particles, which are actual forms of nickel entry into the respiratory tract. The rate of hydrolysis depended on the type of $\mathrm{NiO}$ tested, with nanoparticles being the most effective ones [133]. These results implicated the $\mathrm{Ni}(\mathrm{II})$ exposure as a contributing factor in AATrelated pathologies, in line with previous results, correlating exposure to cigarette smoke and products of fossil fuel combustion with aggravation of AAT deficiency and COPD. Fig. 15 presents the fragment of an AAT structure containing C-terminal cleavage sites, Ala284-Ser285. The N-terminal cleavage sites, Asp12-Thr13 and Thr13-Ser14, occur in the fragment for which the structure has not been determined, and so they are not included in the Fig. 15.

Only the peptide bonds preceding the Ser/Thr residue for $R_{1}$ (Ser/Thr)-Xaa-His-Zaa- $\mathrm{R}_{2}$ sequence pattern were hydrolyzed after the incubation of AAT with Ni(II) compounds. No additional cleavage of protein was observed. This observation confirms the high selectivity of this reaction.

\section{Practical applications of metal-assisted peptide bond hydrolysis}

The general practical aim of research on metal-based agents for peptide bond hydrolysis has been the creation of easy to use and efficient artificial proteases for biotechnological applications. Several intended types of application can be identified in the literature of the subject, such as protein degradation, mimicking the action of exoproteases, protein fragmentation for mass spectrometry applications, protein engineering, including affinity tag removal in protein purification/separation procedures and applications in metal sensing and organic synthesis.

The first of these application types has not been realized practically so far, but several reactions/agents carry some promise for applicability as aminopeptidases. The $\mathrm{Cu}(\mathrm{II})$ complexes of cyclens with an aldehyde group immobilized on the polystyrene, studied by Suh and coworkers, mentioned in Section 2.3.1, revealed the broad substrate activity and short half times. Their properties can be easily modified for example by the addition of catalytic modes to enhance the reaction rate $[70,71]$.

In another development of the work on cyclen complexes by Suh and coworkers several libraries of $\mathrm{Co}$ (III) complexes were designed, synthesized, and derivatized on the cyclen frame [134-136]. Several complexes were active against soluble oligomers of human amyloidogenic peptides: the Alzheimer's Disease $A \beta(1-42)$ peptide, human islet amyloid polypeptide (h-IAPP) related to type 2 diabetes and $\alpha$-synuclein, related to Parkinson's Disease. In a follow-up study, a library of 612 aryl derivatives was obtained, and their $\mathrm{Co}$ (III) complexes were tested as catalysts of hydrolysis of soluble oligomers of $A \beta(1-42)$ and (h-IAPP). The attempts to cleave $A \beta(1-42)$ were unsuccessful, but one derivative was active against h-IAPP. This reactivity was remarkably structure-selective, as the active complex did not hydrolyze the standard monomeric protein targets, BSA, HEWL, bovine heart Mb, and bovine serum $\gamma$-globulin. This study holds promise for a further development of artificial enzymes with high selectivities that could be developed into anti-amyloid drugs [137].

Metal-substituted POMs comprise one of the groups of hydrolytic compounds studied most vigorously in the last few years. Their hydrolytic activity was examined on various proteins using different POM types described in Section 2.3.1 [32,79,80]. The $\mathrm{Zr}(\mathrm{IV})$-substituted Wells-Dawson type POM (1:2 Zr(IV)-WD POM) seems to be the most promising compound from this group so far, but the possibility of introducing a nearly infinite number of modifications into POMs gives a reasonable hope for obtaining even better artificial proteases.

Low sequence specificity, determined by single amino acid residues, primarily His and Met, providing the anchors for the formation of acid stable $\mathrm{Pd}(\mathrm{II})$ and $\mathrm{Pt}(\mathrm{II})$ complexes, was proposed to be turned into an advantage, as providing a facile tool for protein fragmentation in mass spectrometry procedures of protein identification [84]. Among several fragmentation protocols used in these procedures, the most popular one is provided by trypsin, which cleaves peptide bonds flanked by Lys or Arg residues [138]. Therefore, an alternative set of tools, cleaving at Cys, Met and/or His residues should be welcome. Unfortunately, no attempts seem to have been undertaken in this respect, probably because of a lack of familiarity with palladium and platinum chemistry in the proteomics community.

$\left[\mathrm{Pd}(\mathrm{en})\left(\mathrm{H}_{2} \mathrm{O}\right)_{2}\right]^{2+}$ was employed for the purification of a cecropin CMIV expressed as a fusion protein with GST, where the Cys-His unit was incorporated into the N-terminus of cecropin CMIV. The His-Arg peptide bond (Arg is the first amino acid of the cecropin CMIV) was cleaved in a pH-dependent manner. The purified protein has a high antibacterial activity, similar to that observed for the control natural CMIV. Nevertheless, the 
application of $\mathrm{Pd}(\mathrm{II})$ complexes as universal tag cleavage agents is problematic due to number of potential cleavage sites for $\mathrm{Pd}(\mathrm{II})$ compounds in protein sequences [139].

The Cu(II)-dependent cleavage of Ser/Thr-His bond was applied to affinity purity a humanized antibody equipped with C-terminal FLAG tag. Although successful in this particular case, this approach was not converted into a generally applicable procedure [140,141].

Following on their discovery of the $\mathrm{Ca}$ (II)/Mn(II)-dependent autocleavable domain DUF1521, Zehner and collaborators applied it, relabeled as metal ion-inducible autocleavage domain (MIIA) to affinity tag purification of recombinant proteins. They produced two target proteins, MalE and mCherry as MIIA-Strep fusion proteins in E. coli., affinity purified it and cleaved off the C-terminal MIIA-Strep tag on the column and in solution, under very mild conditions ( $\mathrm{pH}$ range from 5.0 to 9.0 at a very low temperature of $6{ }^{\circ} \mathrm{C}$ worked equally well as the room temperature). The reaction was extremely fast (a 90\% yield within 5 min.), and proceeded equally well in conjunction with $\mathrm{Ca}(\mathrm{II})$ and $\mathrm{Mn}$ (II) ions. Its main apparent disadvantage is that a relatively long stretch of the autocleavage domain remains at the C-terminus of the final product [142].

The reaction of $\mathrm{Ni}(\mathrm{II})$ assisted peptide bond hydrolysis according to the acyl rearrangement mechanism has gained the largest number of different applications so far. Its relatively high sequence selectivity approaching that of specific endoproteases, is based on the tetrapeptide pattern which can be summarized as: Ser/Thr[Bulky]-His-[Aromatic]. This selectivity is further enhanced by the requirement of a conformational freedom of the Ser/Thr-[Bulky]His unit, so that the $\mathrm{Ni}(\mathrm{II})$ ion can be bound there in a productive conformation. All amino acid residues required for this specificity are located on one (C-terminal) side of the cleavage site. Therefore, this reaction is well suited for removal of affinity tags located at C-termini of recombinant proteins. This concept was confirmed experimentally for a test protein SPI-2 [143] and demonstrated to yield a very pure protein, suitable for high resolution crystallography studies, with a high efficacy [144]. The affinity tag cleavage (illustrated in Fig. 16) could be performed in solution, but also directly on the affinity column, thus facilitating the process.

Further advantages of this reaction, impossible to be matched by proteases, (but that could be shared by other metal based systems) include its applicability under denaturing conditions and in the presence of detergents. Other recombinant proteins have been purified successfully by this approach in several laboratories, both under native and denaturing conditions [145-147].

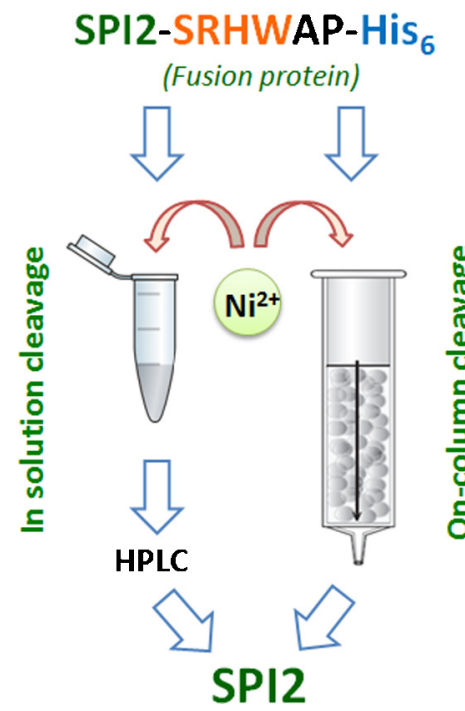

Fig. 16. The purification of a recombinant protein, SPI2-SRHWAP-His 6 using Ni(II)assisted peptide bond cleavage method [143].
This reaction also gave rise to other emerging applications. It was utilized in FRET-based sensors for detection of $\mathrm{Ni}^{2+}$ and $\mathrm{Cu}^{2+}$ ions in water $[148,149]$. It was also applied in organic synthesis to generate active thioesters as building blocks for protein engineering [150].

\section{Conclusions and perspectives}

The review of the field of metal based peptide bond hydrolysis presented above allows us to draw some conclusions regarding the current state of research. Dipeptides were used as convenient models in a large proportion of studies. It seems that the apparent ease of work with dipeptides makes it a kind of a trap, because the N-terminal amine plays a key role in the anchoring of the metal ion to these target molecules. Because of that, the agents proved successful with dipeptides do not necessarily interact with any other peptide or protein targets, or if they do, they may act according to completely different mechanisms. A good example for such behavior is provided by oxo-metal ions and substituted POMs. Experiments on dipeptides revealed that the Xaa-Ser peptide bond was the one most prone for cleavage by these compounds. The presence of the side chain hydroxyl group allows the formation of a transient five-membered ring, which can be easily hydrolyzed by the $\mathrm{N} \rightarrow \mathrm{O}$ rearrangement mechanism (iii) [18]. This process is illustrated in Fig. 17A.

This rule holds for almost all metal compounds studied acting as Lewis acids (Table 1). The acceleration factor ranges from 2.3 for $\mathrm{Zr}(\mathrm{IV}$ )-substituted Lindqvist type polyoxymetalates ( $\mathrm{Zr}(\mathrm{IV})$ - $\mathrm{Ld}$ POMs) to 36 for Ce(IV)-substituted Keggin type polyoxymetalates (Ce(IV)-Kg POMs) [18-20,23,24,27-29,31,32]. For Ser-Gly the intermolecular attack of the hydroxyl group on the carbonyl carbon would require the formation of an unfavorable four-membered ring. This is the reason for the absence of hydrolysis acceleration for Ser-Gly, Fig. 17B.

However, for the proteins, the site of cleavage of oxo- and polyoxo species mostly depends on the electrostatic interaction between the protein surface charge and the charge of hydrolytic agents. Studies of protein cleavage with metal ion complexes focused on several common proteins, such as BSA, HEWL, or myoglobin. As illustrated in the Supporting Information a huge variety of cleavage patterns was observed for given proteins using different hydrolytic agents. No rules can be drawn from the current state of research in this area. Perhaps the most interesting results were obtained for polystyrene immobilized $\mathrm{Cu}(\mathrm{II})$ and $\mathrm{Co}$ (III) cyclen complexes, which provided broad possibilities for increasing selectivity and reactions rates by chemical modifications of the chelating unit $[70,71]$ One can risk an opinion that a large variety of local structures of protein surfaces will make it very difficult to design universal protein cleavage agents that would be able to interact with proteins in a predictable manner.
A

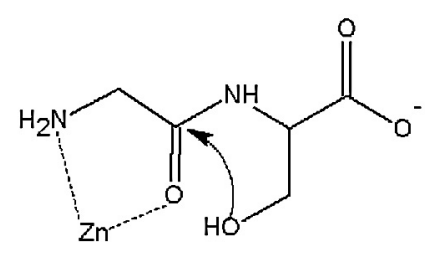

B

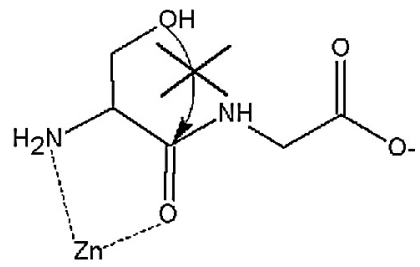

Fig. 17. The comparison of hydrolysis mechanism of Gly-Ser (A) and Ser-Gly (B) dipeptides by $\mathrm{Zn}$ (II) ions according to the polarization of carbonyl group (ii) and $\mathrm{N} \rightarrow \mathrm{O}$ acyl rearrangement types of peptide bond cleavage (iii) [18]. The reaction presented in (B) does not occur, because a four-membered intermediate ring would have to be formed. 


\section{$\mathrm{F}=\mathrm{V}-\mathrm{N}-\mathrm{Q}-\mathrm{H}-\mathrm{T}-\mathrm{C}_{\mathrm{OX}} \mathrm{M}-\mathrm{S} M$}

$$
\mathrm{L}-\mathrm{V}-\mathrm{E}-\mathrm{A}-\mathrm{I}-\mathrm{Y}^{-} \mathrm{I}-\mathrm{V}-\mathrm{C}_{\mathrm{ox}} \mathbf{G}
$$$$
E^{-}-\mathbf{R}-\mathbf{F}-\mathbf{E}-\mathrm{Y}-\mathrm{T}-\mathrm{P}-\mathrm{K}-\mathrm{A}
$$

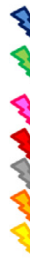

Zr(IV)-substituted 4,13-diaza-18-crown-6 [82]

$\mathrm{Zr}(\mathrm{IV})$-substituted Wells-Dawson $\mathrm{POM}, \mathrm{K}_{15} \mathrm{H}\left[\mathrm{Zr}\left(\alpha_{2}-\mathrm{P}_{2} \mathrm{~W}_{17} \mathrm{O}_{61}\right)_{2}\right] \cdot 25 \mathrm{H}_{2} \mathrm{O}$

(1:2 Zr(IV)-WD-POM) [81]

$\mathrm{CuCl}_{2}[75]$

$\left[\mathrm{CuL}\left(\mathrm{H}_{2} \mathrm{O}\right)\right]^{2+}$, where L is 2-[bis(2-aminoetlyl)amino]ethanol[76]

$\mathrm{ZnCl}_{2}[77]$

cis-[Pt(etlylenediamine) $\left.\left(\mathrm{H}_{2} \mathrm{O}\right)_{2}\right]^{2+}[86]$

cis- $\left[\mathrm{Pd}(\text { ethylenediamine })\left(\mathrm{H}_{2} \mathrm{O}\right)_{2}\right]^{2+}, c i s-\left[\mathrm{Pd}(\text { ethylenediamine }) \mathrm{Cl}_{2}\right]^{2-}$

or cis $-\left[\mathrm{Pd}\left(\text { dithiacyclooctan-3-ol) } \mathrm{H}_{2} \mathrm{O}\right)_{2}\right]^{2+}[47,86]$

Fig. 18. Cleavage sites for the oxidized bovine insulin chain B (the sequence on the basis of the UniProt P01317 record) for different hydrolytic agents $[47,76,77,81,82,86]$

Significant differences in reactivity of the same or similar metal containing agents when applied to peptide bond hydrolysis in proteins vs. very short, and thus unstructured peptides prompted the usage of longer peptides as intermediate model targets. This approach is based on an assumption that such peptides might carry some structural elements, but would not be structured as tightly as test proteins described above. Therefore, the usage of such longer peptides could help discern between the sequence, local structure and charge of protein surface as factors in targeting individual hydrolytic metal compounds. Nevertheless, the reactions of some natural peptides were rather unpredictable.

The comparison of cleavage sites in the oxidized insulin chain B for various metal containing agents is presented in Fig. 18.

Most of the hydrolysis sites for $\mathrm{Cu}(\mathrm{II}), \mathrm{Zn}(\mathrm{II}), \mathrm{Pd}(\mathrm{II})$, and $\mathrm{Pt}(\mathrm{II})$ coincided with the cleavage pattern observed for $\mathrm{Zr}(\mathrm{IV})$ reagents, except for Asn3-Gln4. Based on the mass spectrometry analysis, three binding sites were proposed for $\mathrm{Cu}(\mathrm{II}), \mathrm{Pd}(\mathrm{II})$, and $\mathrm{Pt}(\mathrm{II}) \mathrm{com}$ plexes of oxidized insulin chain $\mathrm{B}$, the $\mathrm{N}$-terminal amine nitrogen, and two imidazole nitrogens of His5 and His10. The His5 and His10 side chains, together with Arg22 were proposed as anchoring sites for $\mathrm{Zn}(\mathrm{II})$ ions. Taken together, the studies of metal-based hydrolysis of oxidized insulin chain B indicated that in unordered or partially ordered peptides specific (anchoring) interactions of metal ions with coordinating side chains played a more significant role in defining the cleavage specificity than electrostatic and hydrophobic interactions that apparently dominated the cleavage of proteins.

The selective peptide bond hydrolysis for proteins, which is based on sequence rather than structure recognition was achieved only for some of the described hydrolytic agents. This approach relies on coordination properties of given metal ions alone (aqua ions) or in coordinatively unsaturated complexes leading to specific interactions with individual amino acid side chains or short sequences. At $\mathrm{pH}$ around 5, Asp-Xaa peptide bonds are selectively cleaved by metal ions as was shown for the HEWL and myoglobin hydrolysis by oxomolybdate and Zr(IV)-substituted POM [78,79]. At a lower $\mathrm{pH} 2.5, \mathrm{Pd}(\mathrm{II})$ and $\mathrm{Pt}(\mathrm{II})$ compounds are effective hydrolytic agents specifically toward the second peptide bond upstream or the first bond downstream from the Met or His residue, respectively $[47,83,84]$.

The highest sequence selectivity and fully predictable cleavage specificity has been achieved in the reaction of $\mathrm{Ni}(\mathrm{II})$ ions with Ser/Thr-Xaa-His sequences. This selectivity is enhanced by the requirement of a conformational freedom of the $\mathrm{Ni}(\mathrm{II})$ binding sequence. As all residues interacting with the $\mathrm{Ni}(\mathrm{II})$ ion are present in the C-terminal hydrolysis product, this reaction is well suited for removal of affinity tags in protein purification procedures $[144,145]$. Its only practical disadvantage is the requirement of an elevated temperature for fast hydrolysis.

This problem is not shared by a tag cleavage procedure which utilizes the $\mathrm{Ca}(\mathrm{II}) / \mathrm{Mn}(\mathrm{II})$ dependent MIIA domain, which is cleaved within minutes at low and temperatures [87,88]. The disadvantage of this process is that a long stretch of unwanted amino acids derived from the cleavage domain remains at the C-terminus of the final protein product. It seems that the future applications of metal assisted peptide bond hydrolysis in biotechnology belong to the latter two approaches, if their weak points will be overcome. There is also some promise in the cyclen complexes, especially in their most recent applications for amyloid digestion [134-137].

\section{Acknowledgments}

This work was supported by the project "Metal dependent peptide hydrolysis. Tools and mechanisms for biotechnology, toxicology, and supramolecular chemistry" (TEAM 2009-4/1) within the Foundation for Polish Science TEAM program, cofinanced by the European Regional Development Fund resources within the framework of Operational Program Innovative Economy (Action 1.2) and Polish National Science Centre, grant no. 2013/11/N/NZ1/02400.

\section{Appendix A. Supplementary data}

Supplementary data associated with this article can be found, in the online version, at http://dx.doi.org/10.1016/j.ccr.2016.02.009.

\section{References}

[1] M.V. Rodnina, M. Beringer, W. Wintermeyer, Quart. Rev. Biophys. 39 (2006) $203-225$

[2] K. Świderek, S. Marti, I. Tuñón, V. Moliner, J. Bertran, J. Am. Chem. Soc. 137 (2015) 12024-12034

[3] L. Pauling, R.B. Corey, H.R. Branson, Proc. Natl. Acad. Sci. USA 37 (1951) 205-211.

[4] A.S. Edison, Nat. Struct. Biol. 8 (2001) 201-202.

[5] A. Radzicka, R. Wolfenden, J. Am. Chem. Soc. 118 (1996) 6105-6109.

[6] I.E. Platis, M.R. Ermacora, R.O. Fox, Biochemistry 32 (1993) 12761-12767.

[7] C.V. Kumar, A. Buranaprapuk, Angew. Chem. Int. Ed. Eng. 36 (1997) 2085-2087.

[8] M.J. Davies, R.J.W. Truscott, J. Photochem. Photobiol. B 63 (2001) 114-125.

[9] M. Kassai, Dissertation, Georgia State University, 2007 http://scholarworks. gsu.edu/chemistry_diss/14〉.

[10] L.E. Sanman, M. Bogyo, Annu. Rev. Biochem. 83 (2014) 249-273.

[11] N.D. Rawlings, G. Sulvesen (Eds.), Handbook of Proteolytic Enzymes, 3rd ed. Academic Press, London, 2013.

[12] F. Soubrier, C. Hubert, P. Testut, S. Nadaud, F. Alhenc-Gelas, P. Corvol, J. Hypertens. 11 (1993) 471-476.

[13] W. Ebeling, N. Hennrich, M. Klockow, H. Metz, H.D. Orth, H. Lang, Eur. J Biochem. 47 (1974) 91-97.

[14] E.R. Stadtman, Annu. Rev. Biochem. 62 (1993) 797-821.

[15] E. Gross, Methods Enzymol. 11 (1967) 238-255.

[16] E. Canova-Davis, M. Eng, V. Mukku, D.H. Reifsnyder, C.V. Olsan, V.T. Ling, Biochem. J. 285 (1992) 207-213.

[17] T.T. Mihaylov, T.N. Parac-Vogt, K. Pierloot, Chem. Eur. J. 20 (2014) 456-466.

[18] M. Yashiro, Y. Sonobe, A. Yamamura, T. Takarada, M. Komiyama, Y. Fujii, Org. Biomol. Chem. 1 (2003) 629-632.

[19] P.H. Ho, K. Stroobants, T.N. Parac-Vogt, Inorg. Chem. 50 (2011) 12025-12033

[20] P.H. Ho, T. Mihaylow, K. Pierloot, T. Parac-Vogt, Inorg. Chem. 51 (2012) 8848-8859.

[21] R.J. Kula, D.L. Rabenstein, Anal. Chem. 38 (1966) 1934-1936.

[22] K. Majlesi, K. Zare, Phys. Chem. Liq. 44 (2006) 257-268.

[23] T. Takarada, M. Yashiro, M. Komiyama, Chem. Eur. J. 6 (2000) 3906-3913.

[24] M. Kassai, R.G. Ravi, S.J. Shealy, K.B. Grant, Inorg. Chem. 43 (2004) 6130-6132.

[25] M. Yashiro, T. Takarada, S. Miyama, M. Komiyama, J. Chem. Soc. Chem. Commun. (1994) 1757-1758.

[26] M. Kassai, K.B. Grant, Inorg. Chem. Commun. 11 (2008) 521-525.

[27] G. Absillis, T.N. Parac-Vogt, Inorg. Chem. 51 (2012) 9902-9910. 
[28] S. Vanhaecht, G. Absillis, T.N. Parac-Vogt, Dalton Trans, 42 (2013) $15437-15446$

[29] H.G.T. Ly, G. Absillis, S.R. Bajpe, J.A. Martens, T.N. Parac-Vogt, Eur. J. Chem. (2013) 4601-4611

[30] H.G.T. Ly, G. Absillis, T.N. Parac-Vogt, Dalton Trans. 24 (2013) 10929-10938.

[31] H.G.T. Ly, T. Mihaylov, G. Absillis, K. Pierloot, T.N. Parac-Vogt, Inorg. Chem. 54 (2015) 11477-11492.

[32] K. Stroobants, E. Moelants, H.G.T. Ly, P. Proost, K. Bartic, T. Parac-Vogt, Chem. Eur. J. 19 (2013) 2848-2858.

[33] L. Meriwether, F.H. Westheimer, J. Am. Chem. Soc. 78 (1956) 5119-5123.

[34] E. Bamann, J.G. Hass, H. Trapmann, Arch. Pharm. 294 (1961) 569-580.

[35] J.P. Collman, D.A. Buckingham, J. Am. Chem. Soc. 85 (1963) 3039-3040.

[36] D.A. Buckingham, J.P. Collman, D.A.R. Happer, L.G. Marzilli, J. Am. Chem. Soc. 89 (1967) 1082-1087.

[37] K.W. Bentley, E.H. Creaser, Biochem. J. 135 (1973) 507-511.

[38] E. Kimura, Inorg. Chem. 13 (1974) 951-954.

[39] K. Jitsukawa, T. Mabuchi, H. Einaga, H. Masuda, Eur. J. Inorg. Chem. (2006) 4254-4263.

[40] A. Erxleben, Inorg. Chem. 44 (2005) 1082-1094.

[41] I.E. Burgeson, N.M. Kostic, Inorg. Chem. 30 (1991) 4299-4305

[42] L. Zhu, N.M. Kostic, Inorg. Chem. 31 (1992) 3994-4001.

[43] T.N. Parac-Vogt, N.M. Kostic, J. Am. Chem. Soc. 118 (1996) 51-58.

[44] M.I. Djuran, S.U. Milinkovic, Polyhedron 19 (2000) 959-963.

[45] M.I. Djuran, S.U. Milinkovic, Polyhedron 18 (1999) 3611-3616.

[46] T.N. Parac, G.M. Ullmann, N.M. Kostic, J. Am. Chem. Soc. 121 (1999) $3127-3135$

[47] N.M. Milovic, N.M. Kostic, Inorg. Chem. 41 (2002) 7053-7063.

[48] T.N. Parac, N.M. Kostic, Inorg. Chem. 37 (1998) 2141-2144.

[49] N.M. Milovic, N.M. Kostic, J. Am. Chem. Soc. 124 (2002) 4759-4769.

[50] N.M. Milović, L.-M. Dutca, N.M. Kostić, Inorg. Chem. 42 (2003) 4036-4045.

[51] N.M. Milović, N.M. Kostić, J. Am. Chem. Soc. 125 (2003) 781-788.

[52] A. Kumar, X. Zhu, K. Walsh, R. Prabhakar, Inorg. Chem. 49 (2010) 38-46.

[53] N.M. Milović, J.D. Badjić, N.M. Kostić, J. Am. Chem. Soc. 126 (2004) 696-697.

[54] T. Zhang, X. Zhu, R. Prabhakar, J. Phys. Chem. 8 (2014) 4106-4114.

[55] S. Rajković, M.D. Živković, C. Kallay, I. Sóvágó, M.I. Djuran, Dalton Trans. 39 (2009) 8370-8377.

[56] S. Rajković, B.D. Glisić, M.D. Živković, M.I. Djuran, Bioorg. Chem. 37 (2009) 173-179.

[57] S. Rajković, D.P. Ašanin, M.D. Živković, M.I. Djuran, Polyhedron 65 (2013) $42-47$.

[58] S. Rajković, U. Rychlewska, B. Warżajtis, D.P. Ašanin, M.D. Živković, M.I. Djuran, Polyhedron 67 (2014) 279-285.

[59] S. Rajković, M.D. Živković, M.I. Djuran, Curr. Protein Pept. Sci. 17 (2016) 95-105.

[60] D.P. Ašanin, M.D. Živković, S. Rajković, B. Warżajtis, U. Rychlewska, M.I. Djuran, Polyhedron 51 (2013) 255-262.

[61] M. Hahn, M. Kleine, W.S. Sheldrick, J. Biol. Inorg. Chem. 6 (2001) 556-566.

[62] M. Kleine, D. Wolters, W.S. Sheldrick, J. Inorg. Biochem. 97 (2003) 354-363.

[63] E.L. Hegg, J.N. Burstyn, J. Am. Chem. Soc. 117 (1995) 7015-7016.

[64] M.C.B. de Oliveira, M. Scarpellini, A. Neves, H. Terenzi, A.J. Bortoluzzi, B. Szpoganics, A. Greatti, A.S. Mangrich, E.M. de Souza, P.M. Fernandez, M.R. Soares, Inorg. Chem. 44 (2005) 921-929.

[65] T.M. Rana, C.F. Meares, J. Am. Chem. Soc. 112 (1990) 2457-2458.

[66] C.V. Kumar, J. Thota, J. Inorg. Chem. 44 (2005) 825-827.

[67] V. Rajendinar, M. Palaniandavar, P. Swaminathan, L. Uma, Inorg. Chem. 46 (2007) 10446-10448.

[68] C.V. Kumar, A. Buranaprapuk, A. Cho, A. Chaudhari, Chem. Commun. (2000) 597-598.

[69] J.W. Jeon, S.J. Son, C.E. Yoo, I.S. Hong, J. Suh, Bioorg. Med. Chem. 11 (2003) $2901-2910$.

[70] C.E. Yoo, P.S. Chae, J.E. Kim, E.J. Jeong, J. Suh, J. Am. Chem. Soc. 125 (2003) $14580-14589$

[71] S.H. Yoo, B.J. Lee, H. Kim, J. Suh, J. Am. Chem. Soc. 127 (2005) 9593-9602.

[72] S.W. Jang, J. Suh, Org. Lett. 10 (2008) 481-484.

[73] H.M. Kim, B. Jang, Y.E. Cheon, M.P. Suh, J. Suh, J. Biol. Inorg. Chem. 14 (2009) $151-157$

[74] T. Zhang, X. Zhu, R. Prabhakar, Organometallics 33 (2014) 1925-1935

[75] X.M. Luo, W.J. He, Y.Zhang, Z.J. Guo, L.G. Zhu, Chin. J. Chem. 18 (2000) 855-862

[76] J. Hong, R. Miao, C. Zhao, J. Jiang, H. Tang, Z. Guo, L. Zhu, J. Mass Spectrom. 41 (2006) 1061-1072

[77] J. Jiang, Y.H. Mei, L.G. Zhu, W.J. Wang, Chin. Chem. Lett. 18 (2007) 557-560.

[78] K. Stroobants, P.H. Ho, E. Moelants, P. Proost, T.N. Parac-Vogt, J. Inorg. Biochem. 136 (2014) 73-80.

[79] H.G.T. Ly, G. Absillis, R. Janssens, P. Proost, T.N. Parac-Vogt, Angew. Chem. 54 (2015) 7391-7394.

[80] K. Stroobants, G. Absillis, E. Moelants, P. Proost, T.N. Parac-Vogt, Chem. Eur. J. 20 (2014) 3894-3897.

[81] A. Sap, G. Absillis, T.N. Parac-Vogt, Dalton Trans. 44 (2015) 1539-1548.

[82] S.S. Cepeda, K.B. Grant, N. J. Chem. 32 (2008) 388-391.

[83] L. Zhu, R. Bakhtiar, N.M. Kostic, J. Biol. Inorg. Chem. 3 (1998) 383-391.

[84] F. Miskevich, A. Davis, P. Leeprapaiwong, V. Giganti, N.M. Kostic, L.A. Angel, J. Inorg. Biochem. 105 (2011) 675-683.

[85] L. Zhu, L. Qin, T.N. Parac, N.M. Kostic, J. Am. Chem. Soc. 116 (1994) 5218-5224.

[86] J. Schirrmeister, L. Friedrich, M. Wenzel, M. Hoppe, C. Wolf, M. Göttfert, S. Zehner, J. Bacteriol. 193 (2011) 3733-3739.
[87] J. Schirrmeister, S. Zocher, L. Flor, M. Göttfert, S. Zehner, FEMS Microbiol. Lett. 343 (2013) $177-182$.

[88] R. Osička, K. Prochazkova, M. Šulc, I. Linhartova, V. Havliček, P. Šebo, J. Biol. Chem. 279 (2004) 24944-24956.

[89] L. Sadilkova, R. Osička, M. Šulc, I. Linhartova, P. Novak, P. Šebo, Protein Sci. 17 (2008) 1834-1843.

[90] S. Manka, F. Becker, O. Hohage, W.S. Sheldrick, J. Inorg. Biochem. 98 (2004) $1947-1956$.

[91] G. Allen, R.O. Campbell, Int. J. Pept. Protein Res. 48 (1996) 265-273.

[92] M.A. Smith, M. Easton, P. Everett, G. Lewis, M. Payne, V. Riveros-Moreno, G Allen, Int. J. Pept. Protein Res. 48 (1996) 48-55.

[93] W. Bal, J. Lukszo, K. Bialkowski, K.S. Kasprzak, Chem. Res. Toxicol. 11 (1998) 1014-1023.

[94] C. Harford, B. Sarkar, Acc. Chem. Res. 30 (1997) 123-130.

[95] W. Bal, J. Christodoulou, P.J.A. Tucker, J. Inorg. Biochem. 70 (1998) 33-39.

[96] H.F. Stanyon, X. Cong, Y. Chen, N. Shahidullah, G. Rossetti, J. Dreyer, G Papamokos, P. Carloni, J.H. Viles, FEBS J. 281 (2014) 3945-3954.

[97] H. Kozłowski, W. Bal, M. Dyba, T. Kowalik-Jankowska, Coord. Chem. Rev. 184 (1999) 319-346.

[98] W. Bal, R. Liang, J. Lukszo, S.H. Lee, M. Dizdaroglu, K.S. Kasprzak, Chem. Res. Toxicol. 13 (2000) 616-624

[99] M. Mylonas, A. Krężel, J.C. Plakatouras, N. Hadjiliadis, W. Bal, J. Chem. Soc., Dalton Trans. (2002) 4296-4306.

[100] A. Krężel, M. Mylonas, E. Kopera, W. Bal, Acta Biochim. Polo. 53 (2006) $721-727$

[101] H. Kozłowski, A. Lebkiri, C.O. Onindo, L.D. Pettit, J.F. Galey, Polyhedron 14 (1995) 211-218.

[102] K. Cherifi, B. Decock-Le Reverend, K. Varnagy, T. Kiss, I. Sovago, C. Loucheux, H. Kozłowski, J. Inorg. Biochem. 38 (1990) 69-80.

[103] J.D. Van Horn, G. Bulaj, D.P. Goldenberg, C.J. Burrows, J. Biol. Inorg. Chem. 8 (2003) 601-610.

[104] A. Krężel, W. Szczepanik, M. Sokołowska, M. Jeżowska-Bojczuk, W. Bal, Chem. Res. Toxicol. 16 (2003) 855-864.

[105] A. Krężel, E. Kopera, A.M. Protas, A. Wyslouch-Cieszynska, J. Poznański, W. Bal, J. Am. Chem. Soc. 132 (2010) 3355-3366.

[106] E. Kopera, A. Krężel, A.M. Protas, A. Belczyk, A. Bonna, A. Wyslouch-Cieszynska, J. Poznański, W. Bal, Inorg. Chem. 49 (2010) 6636-6645.

[107] E. Kurowska, J. Sasin-Kurowska, A. Bonna, M. Grynberg, J. Poznanski, Ł. Kniżewski, K. Ginalski, W. Bal, Metallomics 3 (2011) 1227-1231.

[108] A.M. Protas, H.H. Ariani, A. Bonna, A. Polkowska-Nowakowska, J. Poznański, W. Bal, J. Inorg. Biochem. 127 (2013) 99-106.

[109] H.H. Ariani, A. Polkowska-Nowakowska, W. Bal, Inorg. Chem. 52 (2013) 2422-2431.

[110] E.I. Podobas, A. Bonna, A. Polkowska-Nowakowska, W. Bal, J. Inorg. Biochem. 136 (2014) 107-114.

[111] N.E. Wezynfeld, K. Bossak, W. Goch, A. Bonna, W. Bal, T. Fraczyk, Chem. Res. Toxicol. 27 (2014) 1996-2009.

[112] N.E. Wezynfeld, A. Bonna, W. Bal, T. Frączyk, Metallomics 7 (2015) 596-604.

[113] A. Belczyk-Ciesielska, I. Zawisza, M. Mital, A. Bonna, W. Bal, Inorg. Chem. 53 (2014) 4639-4646

[114] T. Frączyk, N.E. Wezynfeld, K. Bossak, A. Bonna, W. Bal, J. Biol. Inorg. Chem. 19 (2014) S474.

[115] K. Bossak, N.E. Wezynfeld, A. Bonna, W. Bal, J. Biol. Inorg. Chem. 19 (2014) S479

[116] T.W. Muir, Annu. Rev. Biochem. 72 (2003) 249-289.

[117] A.M. Protas, A. Bonna, E. Kopera, W. Bal, J. Inorg. Biochem. 105 (2011) 10-16.

[118] W. Bal, A.M. Protas, K.S. Kasprzak, A. Sigel, H. Sigel, R.K.O. Sigel (Eds.), Metal Ions in Life Sciences Vol. 8, Metal Ions in Toxicology: Effects, Interactions, Interdependencies, The Royal Society of Chemistry, UK, 2011, pp. 319-373.

[119] K.S. Kasprzak, W. Bal, Nickel carcinogenesis, in: R.H. Kretsinger, V.N. Uversky, E.A. Permyakov (Eds.), Encyclopedia of Metalloproteins, Springer, 2013, pp. 1477-1485, 〈http://www.springerreference.com/docs/html/ chapterdbid/358199.html

[120] J.P. Thyssen, T. Menné, Chem. Res. Toxicol. 23 (2010) 309-318.

[121] J.P. Thyssen, D.J. Gawkrodger, I.R. White, A. Julander, T. Menne, C. Liden, Contact Dermat. 68 (2012) 3-14.

[122] C. Svedman, H. Moller, B. Gruvberger, C.G. Gustavsson, J. Dahlin, L. Persson, M. Bruze, Contact Dermat. 71 (2014) 92-97.

[123] Y.S. Hedberg, I. Odnevall Wallinder, Biointerphases 11 (2016) 018901, http:// dx.doi.org/10.1116/1.4934628.

[124] D.P. Mack, P.B. Dervan, Biochemistry 31 (1992) 9399-9405.

[125] W. Bal, J. Lukszo, K.S. Kasprzak, Chem. Res. Toxicol. 10 (1997) 915-921.

[126] W. Bal, M.I. Djuran, D.W. Margerum, E.T. Gray, M.A. Mazid, R.T. Tom, E. Nieboer, P.J. Sadler, J. Chem. Soc., Chem. Commun. (1994) 1889-1890.

[127] B.J. Green, T.M. Tesfai, D.W. Margerum, Dalton Trans. (2004) 3508-3514

[128] W. Bal, K.S. Kasprzak, Toxicol. Lett. 127 (2002) 55-62.

[129] S. Artik, C. von Vultée, E. Gleichmann, T. Schwarz, P. Griem, J. Immunol. 163 (1999) 1143-1152

[130] A.A. Karaczyn, W. Bal, S.L. North, R.M. Bare, V.M. Hoang, R.J. Fisher, K.S. Kasprzak, Chem. Res. Toxicol. 16 (2003) 1555-1559.

[131] A. Belczyk-Ciesielska, B. Csipak, B. Hajdu, A. Sparavier, M.N. Asaka, K. Nagata, B. Gyurcsik, W. Bal, ChemistryOpen (submitted).

[132] N.E. Wezynfeld, W. Bal, T. Frączyk, manuscript in preparation.

[133] N.E. Wezynfeld, W. Bal, T. Frączyk, Toxicol. Lett. 238 S (2015) S141.

[134] J. Suh, S.H. Yoo, M.G. Kim, K. Jeong, J.Y. Ahn, M. Kim, P.S. Chae, T.Y. Lee, J. Lee, J. Lee, Y.A. Jang, E.H. Ko, Angew. Chem. Int. Ed. 46 (2007) 7064-7067. 
[135] J. Suh, W.S. Chei, T.Y. Lee, M.G. Kim, S.H. Yoo, K. Jeong, J.Y. Ahn, J. Biol. Inorg. Chem. 13 (2008) 693-701.

[136] J. Lee, S.H. Yoo, K. Jeong, T.Y. Lee, J.Y. Ahn, J. Suh, Bull. Korean Chem. Soc. 29 (2008) 882-884.

[137] W.S. Chei, H. Ju, J. Suh, J. Biol. Inorg. Chem. 16 (2011) 511-519.

[138] J.V. Olsen, S.-E. Ong, M. Mann, Mol. Cell. Proteom. 3 (2004) 608-614.

[139] F. Dou, F. Qiao, J. Hu, T. Zhu, X. Xu, D. Zhu, L. Zhu, Prep. Biochem. Biotechnol. 30 (2000) 69-78.

[140] D.P. Humphreys, B.J. Smith, L.M. King, S.M. West, D.G. Reeks, P.E. Stephens, Protein Eng. 12 (1999) 179-184.

[141] D.P. Humphreys, L.M. King, S.M. West, A.P. Chapman, M. Sehdev, M.W. Redden, D.J. Glover, B.J. Smith, P.E. Stephens, Protein Eng. 13 (2000) 201-206.

[142] S. Ibe, J. Schirrmeister, S. Zehner, J. Biotechnol. 208 (2015) 22-27.
[143] E. Kopera, A. Belczyk, W. Bal, PLoS One 7 (2012) e36350.

[144] E. Kopera, S. Krzywda, M. Lenarčič Živkovič, A. Dvornyk, B. Kłudkiewicz, K. Grzelak, I. Zhukov, W. Zagórski-Ostoja, M. Jaskólski, W. Bal, PLoS One 9 (2014) e106936.

[145] P.M. Hwang, J.S. Pan, B.D. Sykes, FEBS Lett. 588 (2014) 247-252.

[146] S.Zahran, J.S. Pan, P.B. Liu, P.M. Hwang, Protein Exp. Purif. 116 (2015) 133-138.

[147] A. Belczyk-Ciesielska, P. Gerlach, A. Polkowska-Nowakowska, A. Bonna, W. Bal, manuscript in preparation.

[148] X.-L. Lv, S.-Z. Luo, Anal. Bioanal. Chem. 402 (2012) 2999-3002.

[149] X.-L. Lv, Z. Wei, S.-Z. Luo, Anal. Sci. 28 (2012) 749-752.

[150] Y. Tsuda, A. Shigenaga, K. Tsuji, M. Denda, K. Sato, K. Kitakaze, T. Nakamura, T. Inokuma, K. Itoh, A. Otaka, ChemistryOpen 4 (2015) 448-452. 